Rafael Maso Prévide

\begin{abstract}
AVALIAÇÃO DOS EFEITOS AGUDOS E EM LONGO PRAZO DO HORMÔNIO TIREOIDIANO SOBRE O EIXO HIPOTÁLAMOHIPÓFISE-ADRENAL E SUA IMPORTÂNCIA FISIOLÓGICA
\end{abstract}

Tese apresentada ao programa de PósGraduação em Fisiologia Humana do Instituto de Ciências Biomédicas da Universidade de São Paulo, para obtenção do Título de Doutor em Ciências 


\section{AVALIAÇÃO DOS EFEITOS AGUDOS E EM LONGO PRAZO DO HORMÔNIO TIREOIDIANO SOBRE O EIXO HIPOTÁLAMO- HIPÓFISE-ADRENAL E SUA IMPORTÂNCIA FISIOLÓGICA}

Tese apresentada ao programa de PósGraduação em Fisiologia Humana do Instituto de Ciências Biomédicas da Universidade de São Paulo, para obtenção do Título de Doutor em Ciências

Área de concentração: Fisiologia Humana

Orientadora: Profa. Dra. Maria Tereza Nunes

Versão original 
CATALOGAÇÃO NA PUBLICAÇÃO (CIP)

Serviço de Biblioteca e informação Biomédica do Instituto de Ciências Biomédicas da Universidade de São Paulo

Ficha Catalográfica elaborada pelo(a) autor(a)

Maso Prévide, Rafael

Avaliação dos efeitos agudos e em longo prazo do hormônio tireoidiano sobre o eixo hipotálamo-hipófise adrenal e sua importância fisiológica / Rafael Maso Prévide; orientadora Maria Tereza Nunes. -- São Paulo, 2016

$83 \mathrm{p}$.

Tese (Doutorado)) -- Universidade de São Paulo, Instituto de Ciências Biomédicas.

1. Triiodotironina. 2. Hipófise. 3. TSH. 4. АСTH. 5. Adrenal. I. Nunes, Maria Tereza, orientador. II. Título. 


\section{UNIVERSIDADE DE SÃO PAULO \\ INSTITUTO DE CIÊNCIAS BIOMÉDICAS}

Candidato(a): Rafael Maso Prévide

Título da Tese: Avaliação dos efeitos agudos e em longo prazo do hormônio tireoidiano sobre o eixo-hipotálamo-hipófise-adrenal e sua importância fisiológica

Orientador(a): Profa. Dra. Maria Tereza Nunes

A Comissão Julgadora dos trabalhos de Defesa da Tese de Doutorado, em sessão pública realizada a ..................., considerou

\section{( ) Aprovado(a) ( ) Reprovado(a)}

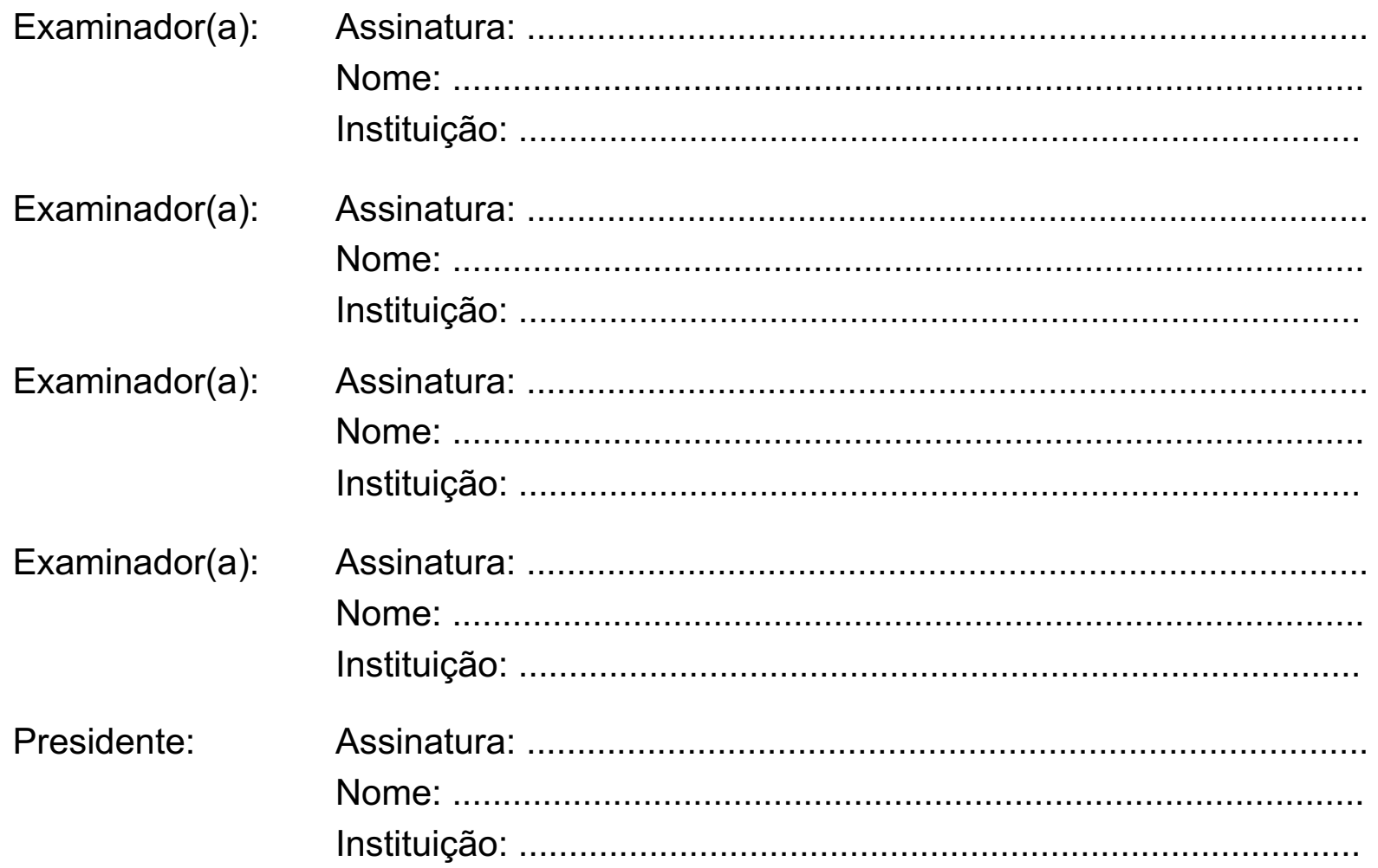




\section{Certificado}

Certificamos que o protocolo registrado sob n 196 nas fls. 116 do livro 02 para uso de animais em experimentação, sob a responsabilidade do Prof(a) Dr(a)) Maria Tereza Nunes, Coordenador (a) da Linha de pesquisa "Ações não genômicas da triiodotironina sobre o corticotrofo" do qual participam o(s) aluno(s) Rafael Maso Prévide, está de acordo com os Princípios Éticos de Experimentação Animal adotado pela Sociedade Brasileira de Ciência de Animais de Laboratório (SBCAL) e foi aprovado pela COMISSÃO DE ÉTICA NO USO DE ANIMAIS (CEUA) em 24.01.2012, com validade de 4 anos.

São Paulo, 27 de janeiro de 2012.
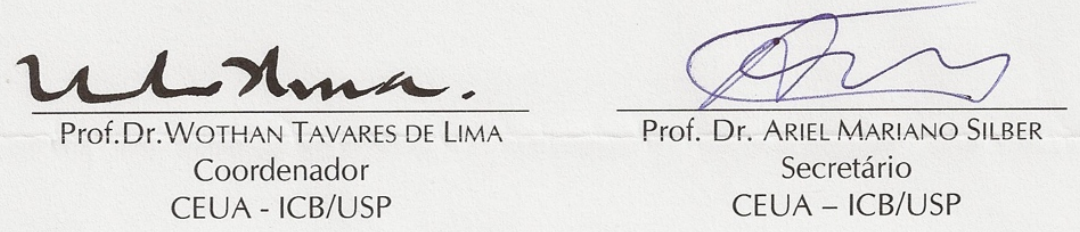
Dedico este trabalho aos meus pais, Archimedes e Maria Edna, por todo o carinho e apoio para chegar até aqui. 


\section{Agradecimentos}

Agradeço a profa. Maria Tereza Nunes por ter me acolhido em seu laboratório. Tereza, você é um exemplo de caráter e amor a sua profissão. Tenho muito orgulho de falar que fui seu orientado.

Agradeço a Lhô pelo apoio no laboratório, pelas palavras de conforto nas horas difíceis e pelas risadas que a gente sempre acaba dando.

Às minhas colaboradoras nesse projeto, Paula e Mariana, pela ajuda nos experimentos e pelas discussões realizadas.

Aos meus amigos de São Paulo e de Franca. Giovanni, Daniel, Álvaro, Leo Barduco, Laine, Kamila, Nelson, Dani, Julieta, Ângela, Leo Barbosa, Richele e Roberto. Sou amigo de alguns de vocês há muito mais de 10 anos e de outros nem faz tanto tempo.... Só sei que quando a gente se encontra tudo fica mais leve, mais feliz e o único problema é que o tempo passa rápido demais. Pessoal, obrigado por sempre estarem presentes, de uma forma ou de outra!

Aos meus amigos do laboratório, Jamile, Ana Ca, Carol, Mari, Paulinha, Croffi, Rafa Jr., Fred, Cecília, Lucas, Silvania e Rafa Dias. Pessoal, foi muito bom estar com vocês nesses 4 anos. Trabalhamos muito, nos ajudamos, demos muitas risadas e dividimos a mesa do almoço diariamente. Obrigado por tudo pessoal.

Ao meu chefe do NIH, Stanko Stojilkovic, por ter me recebido em seu laboratório para realização do estágio no exterior. Agradeço também a Marija, Milos, Melanija e XinJie pelas conversas, ensinamentos e todas as músicas sérvias que escutamos juntos!

Aos secretários de pós-graduação José Maria e Paloma, que sempre me ajudaram de bom grado.

À CAPES e ao CNPq pelo apoio financeiro no formato de bolsa de doutorado. 
"Desistir... eu já pensei seriamente nisso, mas nunca me levei realmente a sério; é que tem mais chão nos meus olhos do que o cansaço nas minhas pernas, mais esperança nos meus passos, do que tristeza nos meus ombros, mais estrada no meu coração do que medo na minha cabeça."

Cora Coralina 


\section{RESUMO}

PRÉVIDE, R. M. Avaliação dos efeitos agudos e em longo prazo do hormônio tireoidiano sobre o eixo hipotálamo-hipófise-adrenal e sua importância fisiológica. $2016.83 \mathrm{f}$. Tese (Doutorado em Fisiologia Humana) - Instituto de Ciências Biomédicas, Universidade de São Paulo, São Paulo, 2016.

Os hormônios tireoidianos (HTs) participam de diversos processos biológicos, por meio de ações que exercem sobre a expressão de genes que codificam proteínas envolvidas com o metabolismo, crescimento e desenvolvimento, ações essas conhecidas como genômicas. Todavia, algumas ações dos HTs são desencadeadas na presença de inibidores da transcrição gênica, indicando que eles exercem também ações não genômicas. Poucos são os estudos que exploram a participação dos HTs na regulação do eixo hipotálamo-hipófise-adrenal, portanto, o presente estudo tem o objetivo de caracterizar as ações rápidas (30'), bem como as que ocorrem em longo prazo (5 dias) do T3 sobre a síntese de POMC e secreção de ACTH em cultura de células AtT-20 e em ratos submetidos a tireoidectomia (Tx) e posteriormente tratados com triiodotironina em doses fisiológicas e supra fisiológicas. Também verificamos a ação do T3 em cultura primária de adrenais e a ação do TSH em cultura primária de hipófises. Após esses tratamentos avaliamos a expressão de mRNA de POMC, CRH, PC1, StAR, CYP11A1, CYP11B1, CYP11B2, 3 $\beta$-HSD e SF-1 por qPCR, o conteúdo de POMC/ACTH por western blotting e a secreção de ACTH e corticosterona. Detectamos nos ratos Tx uma redução do conteúdo de mRNA da POMC, em paralelo a um aumento da sua cauda poli(A). O tratamento com T3 em dose suprafisiológica por 30 minutos ou 5 dias promoveu um aumento na expressão deste mRNA, embora os valores obtidos tenham sido inferiores aos detectados no grupo controle. Quanto ao conteúdo de POMC e ACTH, observamos que este permanece inalterado tanto no tratamento crônico, como no agudo com T3. A enzima PC1 tem sua expressão aumentada em ratos $\mathrm{Tx}$, fato esse revertido a níveis iguais ao do controle pelo tratamento com T3. As enzimas responsáveis pela esteroidogênese e a corticosterona sérica não apresentaram diferenças entre tratamentos nos grupos estudados in vivo, apesar da redução sérica de ACTH em animais Tx, porém SF-1 teve sua expressão aumentada in vitro após tratamento com T3. Na cultura de hipófises, o TSH se mostrou capaz de aumentar a secreção de ACTH sem alteração de transcrição gênica de POMC e esse mecanismo pode ter a participação do AMPc e cálcio. $\mathrm{O}$ mRNA de POMC se reduziu quando as células AtT-20 foram cultivadas por 24 horas em meio depletado de HTs, situação que foi revertida quando as células foram tratadas por 30 minutos com T3 na dose $10^{-9} \mathrm{M}$. O tratamento dessas células com o peptídeo RGD provocou a perda desse efeito, sugerindo uma ação de membrana. O tratamento prévio das células com actinomicina $\mathrm{D}$ também preveniu este efeito do T3. Estes dados sugerem que essa ação rápida do T3 é desencadeada primariamente na membrana celular e que envolve mecanismos que levam à indução da transcrição desse gene. Conclui-se que a ausência de T3 reduz o conteúdo de mRNA da POMC e a secreção de ACTH pela hipófise, apesar de mecanismos compensatórios estarem ativados e o TSH se mostrou um novo fator parácrino estimulante da secreção de ACTH em cultura primária de hipófise.

Palavras-chave: Triiodotironina. Hipófise. TSH. ACTH. Adrenal 


\begin{abstract}
PRÉVIDE, R. M. Acute and long therm effects of thyroid hormones on the hypothalamicpituitary-adrenal axys and its physiological importance. 2016. $83 \mathrm{p}$. $\mathrm{Ph}$. D. Thesis (Human Physiology) - Instituto de Ciências Biomédicas, Universidade de São Paulo, São Paulo, 2016.
\end{abstract}

Thyroid hormones $(\mathrm{TH})$ participate in many biological processes, regulating the expression of genes that encode proteins involved in the metabolism, growth and development, actions these known as genomic actions. However, some actions of HTs are triggered in the presence of inhibitors of gene transcription and in short time, indicating that they also perform non genomic actions. There are few studies that explore the participation of HTs in the regulation of the hypothalamic-pituitary-adrenal axis, therefore, the present study aims to characterize T3 quick actions (30') as well as those that occur in long-term (5 days) on POMC synthesis and ACTH secretion in AtT-20 cell culture and in rats subjected to thyroidectomy (Tx) and then treated with physiological and supraphysiological doses of T3. We also verified T3 actions in primary culture of adrenals and the action of TSH in primary cultures of pituitary glands. After these treatments we evaluated mRNA expression. of POMC, CRH, PC1, StAR, CYP11A1, CYP11B1, CYP11B2, 3-HSD and SF-1 by qPCR, the content of POMC/ACTH by western blotting and secretion of ACTH and corticosterone. A reduction on POMC mRNA content was detected in Tx rats in parallel to an increase of their poly (A) tail. Treatment with T3 in supraphysiological dose for 30 minutes or 5 days promoted an increase in the expression of POMC mRNA, although the values were lower than those detected in the control group. As for the content of POMC and ACTH, we observed that it remained unchanged both in the chronic and acute treatments. PC1 enzyme had its expression increased in Tx rats, which is reverted to levels equal to control group by $\mathrm{T} 3$ treatment. The enzymes responsible for steroidogenesis and serum corticosterone showed no differences between treatments in the in vivo studied groups, despite the reduction of serum ACTH in Tx animals, but SF-1 had its expression increased in vitro after treatment with $\mathrm{T} 3$. In pituitary primary culture, TSH increased $\mathrm{ACTH}$ secretion with no alteration of POMC mRNA content and this mechanism may be mediated by cAMP and calcium. POMC mRNA was reduced when AtT-20 cells were cultured for 24 hours in medium depleted of TH and this situation was reversed when cells were treated for 30 minutes with T3 $10^{-9} \mathrm{M}$. Treatment of these cells with RGD peptide prevented POMC mRNA increase in response to T3, suggesting that this T3 action depends on its binding to the membrane protein. Pretreatment of cells with actinomycin D also prevented this effect of T3. These data together suggest that this rapid action of T3 is triggered primarily in the cell membrane and involves mechanisms that lead to subsequent induction of POMC gene transcription. We conclude that $\mathrm{T} 3$ absence reduces POMC mRNA content and ACTH secretion by the pituitary due to a possible cytoskeleton impairment, although compensatory mechanisms are activated and TSH showed a new stimulating paracrine factor of ACTH secretion in primary culture of pituitary gland.

Keywords: Triiodothyronine. Pituitary. TSH. ACTH. Adrenal 


\section{Lista de figuras}

Figura 1 - Receptores nucleares de hormônios tireoidianos. 20

Figura 2 - Mecanismo de ação receptores nucleares de hormônios tireoidianos. .20

Figura 3 - Ações não genômicas dos HTs. .22

Figura 4 - Estudo crônico - Peso seco do coração. .42

Figura 5 - Estudo crônico - Expressão de mRNA da POMC na hipófise. . .43

Figura 6 - Estudo crônico - Expressão de mRNA da PC1 na hipófise. .44

Figura 7 - Estudo crônico - Conteúdo proteico de POMC e ACTH na hipófise. .45

Figura 8 - Estudo crônico - Expressão de mRNA do CRH na hipófise. 46

Figura 9 - Estudo crônico - Peso das adrenais.

Figura 10 - Estudo crônico - Expressão de mRNA da StAR na adrenal. .47

Figura 11 - Estudo crônico - Expressão de mRNA da CYP11A1 na adrenal. .48

Figura 12 - Estudo crônico - Expressão de mRNA da CYP11B1 na adrenal. . .48

Figura 13 - Estudo crônico - Expressão de mRNA da CYP11B2 na adrenal. .49

Figura 14 - Estudo crônico - Dosagem sérica de ACTH. .50

Figura 15 - Estudo crônico - Dosagem sérica de corticosterona. .50

Figura 16 - Estudo agudo - Expressão de mRNA da POMC na hipófise. .51

Figura 17 - Estudo agudo - Comprimento cauda poli(A) mRNA da POMC. . .52

Figura 18 - Estudo agudo - Perfil polissomal na hipófise. .53

Figura 19 - Estudo agudo - Conteúdo proteico de POMC e ACTH na hipófise. .54

Figura 20 - Estudo agudo - Dosagem sérica de ACTH. .55

Figura 21 - Estudo agudo - Dosagem sérica de corticosterona. .55

Figura 22 - Cultura primária de hipófise - Efeito do T3 e do CRH na secreção de ACTH .56

Figura 23 - Cultura primária de hipófise - Detecção de mRNA do TSHR .57 
Figura 24 - Cultura primária de hipófise - Efeito do tratamento com TSH na expressão de

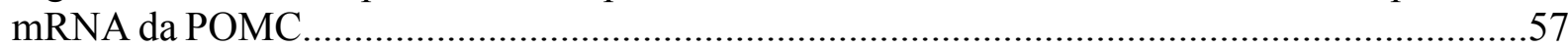
Figura 25 - Cultura primária de hipófise - Efeito do TRH e TSH na secreção de ACTH em

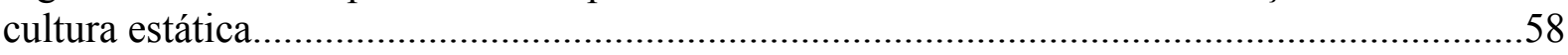

Figura 26 - Cultura primária de hipófise - Perifusão de células hipofisárias com TSH. .59

Figura 27 - Cultura primária de hipófise - Detecção de cálcio citosólico em corticotrofos após tratamento com TSH.

Figura 28 - Cultura primária de hipófise - Detecção de cálcio citosólico em corticotrofos após tratamento com TSH em células previamente tratadas com antalarmina.

Figura 29 - Cultura primária de hipófise - Avaliação do conteúdo de AMPc no meio de cultura.

Figura 30 - Cultura primária de hipófise - Avaliação do conteúdo de AMPc intracelular.

Figura 31 - Cultura primária de adrenal - Expressão do mRNA de SF1 após tratamento com T3.

Figura 32 - Cultura primária de adrenal - Expressão do mRNA de CYP11B1, 3 $\beta$-HSD, StAR e Mc2R após tratamento com T3.

Figura 33 - Cultura de células AtT-20 - Curva de tempo para tratamento com soro depletado de hormônio tireoidiano.

Figura 34 - Cultura de células AtT-20 - Padronização da dose de T3 utilizada. .64

Figura 35 - Cultura de células AtT-20 - Avaliação da viabilidade celular em células tratadas com soro controle.

Figura 36 - Cultura de células AtT-20 - Avaliação da viabilidade celular em células tratadas com soro tratado com resina por $24 \mathrm{~h}$.

Figura 37 - Cultura de células AtT-20 - Efeito do tratamento com actinomicina D na expressão do RNAm da POMC após tratamento com T3 por $30 \mathrm{~min}$

Figura 38 - Cultura de células AtT-20 - Verificação da presença do mRNA das subunidades $\alpha \mathrm{V}$ e $\beta 3$

Figura 39 - Cultura de células AtT-20 - Efeito do tratamento com RGD na expressão do RNAm da POMC após tratamento com T3. 


\section{Lista de tabelas}

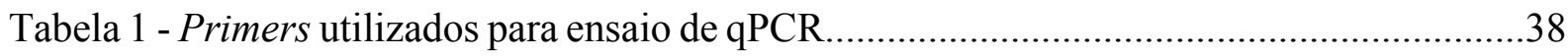




\section{Lista de abreviaturas}

3ßHSD - 3 Beta hidroxi-esteróide desidrogenase

ACTH - Hormônio adrenocorticotrófico

AMPc - 3'5'-adenosina-monofosfato-cíclico

ATP - Trifosfato de adenosina

AVP - Arginina vasopressina

BSA - Albumina sérica bovina

Ca2+-APTase -

CRH - Hormônio liberador de corticotropina

DAG - Diacilglicerol

DEPC - Dietilpirocarbonato

DMEM - Meio modificado de Dulbecco

DNA - Ácido desoxirribonucleico

EDTA - Ácido etilenodiamino tetra-acético

ELISA - Ensaio de imunoabsorção enzimática

ER $\alpha$ - Receptor de estrógeno $\alpha$

GAPDH - Gliceraldeído-3-fosfato desidrogenase

GH - Hormônio do crescimento

HHA - Hipotálamo-hipófise-adrenal

HHT - Hipotálamo-hipófise-tireóide

HT - Hormônio tireoidiano

IBMX - 3-isobutil-1-metilxantina

IGF-1 - Fator de crescimento semelhante à insulina tipo 1

$\mathrm{IP}_{3}-$ Trifosfato de inositol

LH - Hormônio luteinizante

MAPK - Mitogen-activated protein kinase

Mc2R - Receptor de melanocortina 2

MEM - Meio essencial mínimo

mRNA - RNA mensageiro

$\mathrm{Na}+, \mathrm{K}+$-ATPase -

$\mathrm{NIH}$ - National Institutes of Health 
PBS - Tampão fosfato salina

PI3K - Phosphatidylinositol-4,5-bisphosphate 3-kinase

POMC - Proopiomelanocortina

qPCR - PCR quantitativo em tempo real

RACE-PAT - Rapid Amplification of cDNA Ends - Poly A Test

RIA - Radioimunoensaio

RIPA - Tampão para radioimunoprecipitação

RNA - Ácido ribonucleico

rT3 - Triiodotironina reverso

SF-1 - Fator esteroidogênico 1

SFB - Soro fetal bovino

StAR - Proteína regulatória esteroidogênica aguda

T2- Diiodotironina

T3 - Triiodotironina

T4 - Tiroxina

TBG - Globulina ligadora de tiroxina

TBS - Salina tamponada com Tris

THR $\beta$ - Receptor de hormônio tireoidiano $\beta$

TRH - Hormônio liberador de tireotropina

TSH - Hormônio tireotrófico

TSHR - Receptor de hormônio tireotrófico

UV - Ultravioleta 


\section{SUMÁRIO}

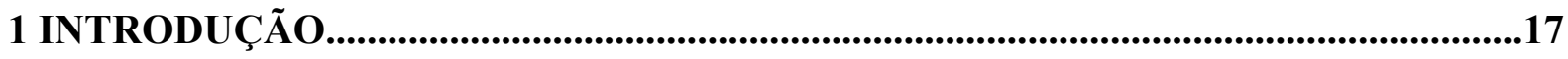

1.1 Hormônios tireoidianos - Biossíntese, regulação e mecanismos de ação.........................17

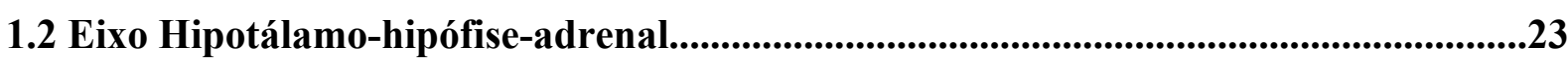

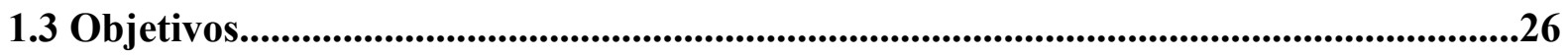

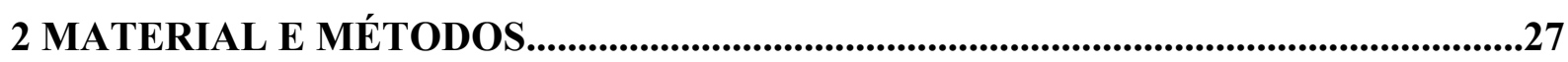

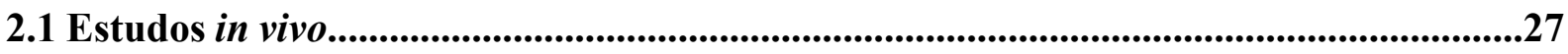

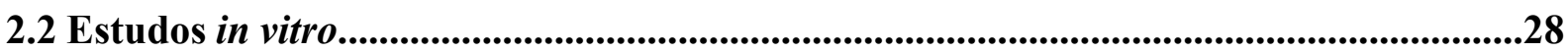

2.2.1 Preparo de Soro Fetal Bovino e Soro de Cavalo com resina Ag1-X8.................................28

2.2.2 Cultura primária de hipófises.............................................................................................29

2.2.3 Secreção estática em cultura primária de hipófises..........................................................30

2.2.4 Perifusão de células hipofisárias.........................................................................................30

2.2.5 Medida da concentração de 3'5'-adenosina-monofosfato-cíclico (AMPc) intracelular e

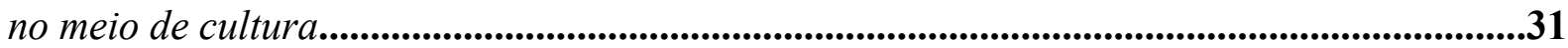

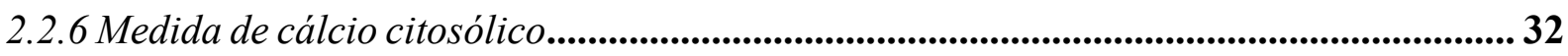

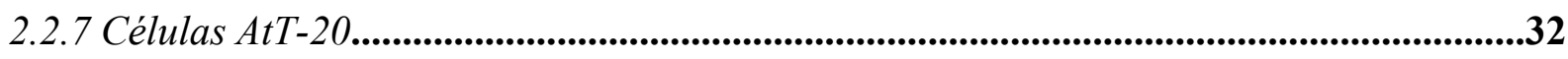

2.2.8 Efeito do tratamento com T3 sobre a expressão gênica da proopiomelanocortina na presença do bloqueador de transcrição gênica actinomicina D....................................................33

2.2.9 Efeito do T3 sobre a expressão gênica da proopiomelanocortina na presença do bloqueador sítio de ligação à integrina de membrana $\alpha V \beta 3$....................................................34

2.2.10 Cultura primária da glândula adrenal ......................................................................35

2.3 Avaliação da expressão gênica..................................................................................36

2.4 Avaliação do grau de adenilação do mRNA da POMC por RACE-PAT: Rapid Amplification of cDNA Ends - Poly A Test..............................................................................39

2.5 Perfil polissomal..............................................................................................................................39

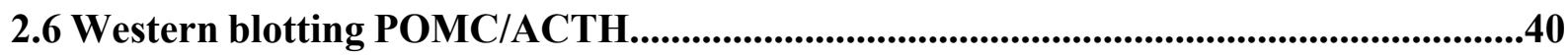

2.7 Dosagem ACTH e corticosterona.......................................................................................41

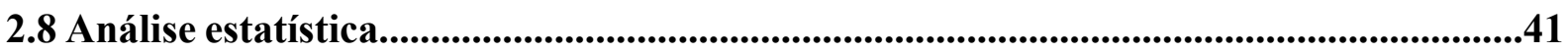

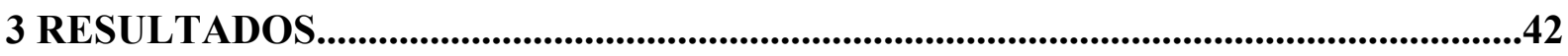

3.1. Estudos in vivo - Tratamento crônico com T3 .................................................................42

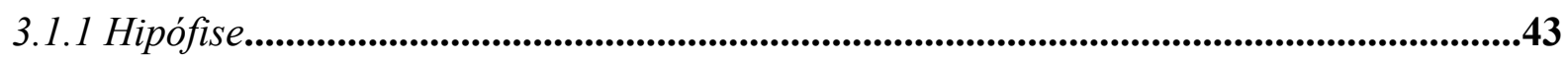

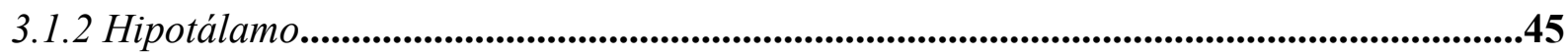


3.1.3 Adrenais................................................................................................................................46

3.1.4 Dosagem sérica de ACTH e corticosterona .........................................................................49

3.2 Estudos in vivo - Tratamento agudo com T3.......................................................................51

3.3 Estudos in vitro.........................................................................................................................56

3.3.1 Cultura primária de hipófise..........................................................................................56

3.3.2 Cultura primária de adrenal.....................................................................................62

3.3.3 Cultura de células AtT-20....................................................................................63

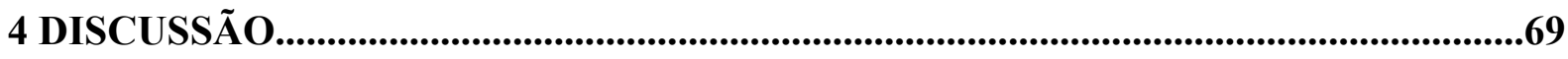

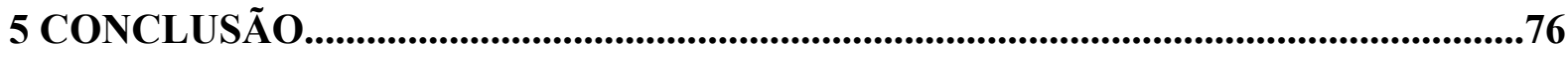

REFERÊNCIAS............................................................................................................77 


\section{INTRODUÇÃO}

\subsection{Hormônios tireoidianos - Biossíntese, regulação e mecanismos de ação}

A glândula tireoide foi descrita em 1656 por Thomas Wharton e acreditava-se que a sua função era de embelezar o pescoço. Somente no fim do século 19 foi descoberto que a glândula exercia um papel funcional no organismo. Observou-se que o cretinismo e o mixedema (hipotireoidismo adulto) estavam associados a atrofia da glândula tireoide e a remoção da glândula tireoide provocava alterações semelhantes ao mixedema (LINDHOLM; LAURBERG, 2011). Já em 1891 foi detectado que o mixedema poderia ser tratado com injeções diárias de extrato de tireoide de ovelha e algum tempo depois foi obervado que tireoides levemente cozidas provocavam o mesmo efeito. Após estas evidencias, foi proposto que a tireoide produziria um composto que quando ausente causaria o mixedema (GALTON, 2013).

Em 1914, um composto contendo 65,3\% de iodo foi isolado por Edward Kendall, porém só em 1927 a tiroxina (T4) foi quimicamente caracterizada. Outro composto produzido pela tireoide, a triiodotironina, foi descoberto por Gross e Pitt-Rivers em 1952 (LINDHOLM; LAURBERG, 2011).

A síntese dos hormônios tireoidianos (HTs) ocorre a partir da absorção ativa de iodeto pela proteína NIS, presente na tireóide e também em outros órgãos como intestino, glândulas salivares e na glândula mamária (PORTULANO; PARODER-BELENITSKY; CARRASCO, 2014). Na tireóide, após a absorção, o iodeto é transportado para o lúmen do folículo pela proteína apical denominada pendrina. No lúmen o iodeto é oxidado pela enzima TPO num processo catalisado pelo peróxido de hidrogênio e é incorporado nos resíduos de tirosina da tireoglobulina, passo também catalisado pela TPO. Nesse processo, denominado organificação do iodo, ocorre a formação de monoiodotirosina (MIT) ou diiodotirosina (DIT). Após a formação de DIT e MIT, essas sofrem um processo também catalisado pela TPO onde são acopladas ocorrendo a formação de T3, T4, rT3 e T2. Através da ação do TSH, a tireoglobulina é englobada pela célula folicular e é hidrolisada nos lisossomos liberando T3, T4, rT3, T2, MITs e DITs. MITs e DITs tem seu iodo removido para reaproveitamento enquanto os hormônios são secretados para a circulação (KIMURA, 2008; YEN, 2001).

O processo de síntese e secreção dos HTs está sobre regulação do eixo hipotálamohipófise-tireóide. No hipotálamo, mais precisamente no núcleo paraventricular, o hormônio liberador de tireotropina (TRH) é sintetizado. Após ser liberado na eminência mediana ele é 
transportado pela circulação porta hipofisária até a adeno-hipófise, ou hipófise anterior onde se liga ao seu receptor, TRHR, presente nos tireotrofos e lactotrofos. Nos tireotrofos, a ativação do TRHR provoca aumento na síntese e secreção de hormônio tireotrófico (TSH) (JOSEPHBRAVO et al., 2015). A ação clássica do TSH ocorre nos tireócitos, onde o mesmo age no receptor de TSH, TSHR. Ao se ligar a este receptor o TSH desencadeia a ativação tanto de Gs como de Gq. A ativação de Gs provoca liberação da subunidade alfa e ativação da adenilato ciclase, enzima responsável pela conversão de ATP em AMPc. Essas ações causadas pela ativação de Gs estão envolvidas com crescimento de tecido tireoidiano e secreção hormonal. Já a ativação de $\mathrm{Gq}$ ativa a fosfolipase $\mathrm{C}$ e controla a síntese hormônios na tireóide (DUPREZ et al., 1998; RICHARDS, 2008). Os hormônios T4 e T3 são então liberados pela tireóide e a sua própria produção também é responsável pela regulação de sua síntese, uma vez que esses hormônios são responsáveis pelo feedback negativo no hipotálamo e na hipófise, onde o T4 tem um papel mais importante que o T3 na regulação da síntese e secreção de TRH e TSH (ZOELLER; TAN; TYL, 2007).

No entanto, é necessário ficar claro que o TSH não age apenas na tireóide. O TSHR já foi descrito em outros tecidos, como no tecido adiposo (SORISKY; BELL; GAGNON, 2000), na hipófise (BROKKEN et al., 2001; PRUMMEL et al., 2000), nos rins, cérebro, coração, ossos, linfócitos e testículos (DAVIES; MARIANS; LATIF, 2002), tecidos nos quais exerce efeitos diferentes dos que exerce na tireóide. No tecido adiposo, o TSH regula a lipólise e está envolvido no processo de desenvolvimento e remodelamento de pré-adipócitos. Já na hipófise, ele foi localizado nas células folículo estreladas e os autores acreditam que seu papel seja de regulação fina da secreção de TSH, já que essas células se localizam próximas aos tireotrofos (PRUMMEL, et al., 2000).

Voltando aos HTs, o T4 circulante é sintetizado totalmente pela tireóide enquanto apenas 20\% do T3 circulante é gerado pela glândula (KIMURA, 2008; YEN, 2001). Os 80\% restantes são gerados pela desiodação do T4, sendo sua disponibilidade regulada pela atividade das desiodases, que são divididas em três tipos. As desiodases do tipo 1 são expressas principalmente no fígado, rins, tireóide e hipófise; as do tipo 2 no sistema nervoso central, adeno-hipófise, tecido adiposo marrom e placenta e as do tipo 3 no sistema nervoso central, placenta, pele e em tecidos fetais (BIANCO et al., 2002; OETTING; YEN, 2007).

Os HTs são transportados na corrente sanguínea ligados a proteínas transportadoras como a proteína ligadora de tiroxina (TBG), a transtirretina e albumina (KIMURA, 2008). Eles são transportados para o interior das células através de transportadores que se encontram na 
membrana celular, dos quais se destacam o transportador de monocarboxilato 8 e 10 (MCT8 e MCT10) no transporte de T3 e o transportador de ânions orgânicos, OATP1C1, para o transporte de T4. O OATP1C1 é altamente expresso em capilares do cérebro, no próprio cérebro e nas células de Leydig, enquanto o MCT8 é expresso no cérebro, coração, fígado, adrenal e glândula tireóide. Já o MCT10 foi descrito no intestino, rim, músculo, placenta e fígado (BERNAL; GUADAÑO-FERRAZ; MORTE, 2015; JANSEN, et al., 2005; VISSER, FRIESEMA; VISSER, 2011).

Os hormônios tireoidianos regulam processos essenciais da vida dos vertebrados como crescimento, desenvolvimento e metabolismo. Eles participam da regulação do peso corporal e gasto energético. O excesso de hormônios tireoidianos causa um estado hipermetabólico, onde ocorre um aumento do gasto energético em repouso, perda de peso, redução do colesterol plasmático, aumento da lipólise e da gliconeogênese. Já no hipotireoidismo predomina um estado de hipometabolismo caracterizado por um reduzido gasto energético em repouso, ganho de peso, colesterol elevado, lipólise e gliconeogênese reduzidas (MULLUR; LIU; BRENT, 2014; OETTING; YEN, 2007).

As ações clássicas dos HTs são chamadas de genômicas e estas são responsáveis pela alteração na síntese de proteínas relacionadas ao crescimento, metabolismo e desenvolvimento. Para desencadear essas ações, os HTs interagem com seus receptores nucleares (THRs), que se ligam a regiões específicas denominadas elementos responsivos aos hormônios tireoidianos presentes na região promotora dos genes alvo provocando aumento ou diminuição de sua transcrição (MULLUR; LIU; BRENT, 2014; SHIBUSAWA et al., 2003). As ações genômicas são conhecidas também pelo fato de demorarem horas ou até mesmo dias para ocorrerem, já que dependem de alterações na expressão gênica da célula alvo e por serem mediadas principalmente pelo $\mathrm{T} 3$.

Os principais THRs são a THR $\alpha 1$, THR $\alpha 2$, THR $\alpha 3$, THR $\beta 1$, THR $\beta 2$ e THR $\beta 3$. Esses receptores possuem 3 domínios funcionais, sendo o primeiro, o domínio amino-terminal, o segundo o domínio de ligação ao DNA e o terceiro o domínio de ligação ao ligante. A região AF-1 encontra-se no primeiro domínio, mas sua função ainda é pouco conhecida. Sugere-se que a região AF-1 tenha a função de dar especificidade à ligação do THR ao TRE. A região AF-2 encontra-se no terceiro domínio, na região carboxi-terminal (Figura 1). Quando o T3 ligase ao receptor, ocorrem mudanças conformacionais no mesmo permitindo a sua ligação a cofatores, podendo esses serem tanto ativadores como inibidores (Fig 2). Entre as isoformas $\alpha$, o THR $\alpha 1$ é a única que possui capacidade de se ligar ao T3. As isoformas 2 e 3 não possuem 
essa capacidade, atuando como elementos dominantes negativos. Eles são encontrados em todos os tecidos, mas em maior quantidade no cérebro e no coração. Já todas as isoformas $\beta$ (1, 2 e 3) são capazes de se ligar ao T3. O THR $\beta 1$ é encontrado em maior quantidade no músculo esquelético, rim e fígado. Já o THRß2 é mais expresso no cérebro, hipófise, retina e orelha interna. O THR $\beta 3$ é expresso somente no rato e é encontrado no pulmão, fígado e rins (CHENG; LEONARD; DAVIS, 2010; OETTING; YEN, 2007; ORTIGA-CARVALHO; SIDHAYE; WONDISFORD, 2014; YEN, 2001).

\begin{tabular}{|c|c|c|c|c|}
\hline Protein & $\begin{array}{l}\text { Able to } \\
\text { bind } T_{3}\end{array}$ & $\begin{array}{l}\text { Able to } \\
\text { form dimers }\end{array}$ & & \\
\hline THRß1 & Yes & Yes & \begin{tabular}{|l|l|l|l|} 
AF-1 & DBD \\
\end{tabular} & AF-2 \\
\hline THRß2 & Yes & Yes & \begin{tabular}{l|l|} 
AF-1 & DBD $=L B D$ \\
\end{tabular} & AF-2 \\
\hline THRß3 & Yes & Yes & \begin{tabular}{|l|l|l|} 
AF-1 & DBD $=$ LBD
\end{tabular} & AF-2 \\
\hline THRa1 & Yes & Yes & \begin{tabular}{|l|l|} 
AF-1 & DBD $=$ LBD \\
\end{tabular} & AF-2 \\
\hline THR 22 & No & Yes & \begin{tabular}{|l|l|} 
AF-1 & DBD $=$ LBD \\
\end{tabular} & \\
\hline THRa3 & No & Yes & \begin{tabular}{|c|c|l} 
AF-1 & DBD $=$ LBD \\
\end{tabular} & \\
\hline
\end{tabular}

Figura 1 - Receptores nucleares de hormônios tireoidianos (THRs). AF-1, fator de ativação 1, DBD, Domínio de ligação ao DNA, LBD, Domínio de ligação ao ligante, AF-2, fator de ativação 2. Adaptado de Ortiga-Carvalho, Sidhaye e Wondisford, 2014.

Nos genes que são regulados positivamente pelo T3, os THRs encontram-se já ligados aos TREs, porém associados à co-repressores, impedindo assim que ocorra a transcrição gênica (fig 2). Quando o T3 se liga ao seu receptor nuclear, ocorre a liberação do co-repressor e a ligação de um co-ativador, o que dá início a transcrição gênica e consequente aumento do respectivo mRNA (KIMURA, 2008; OETTING; YEN, 2007; YEN, 2001). 

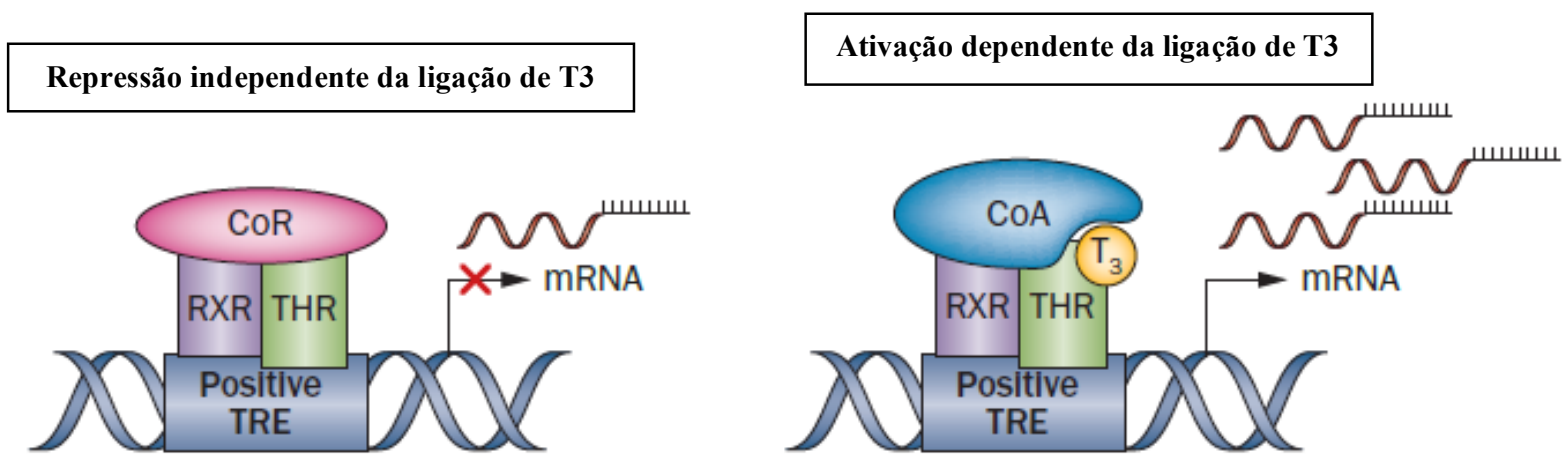

Figura 2 - Mecanismo de ação do T3 em seus receptores nucleares. THR, receptor de hormônio tireoidiano, RXR, receptor $\mathrm{X}$ retinóide, Positive TRE, elemento responsivo positivo ao hormônio tireoidiano, CoR, co-repressor, CoA, co-ativador. Adaptado de Ortiga-Carvalho, Sidhaye e Wondisford, 2014.

O hormônio tireoidiano também pode desencadear respostas em curto espaço de tempo, sendo essas ações denominadas não genômicas. Elas diferem das ações genômicas por se iniciarem na membrana ou no citoplasma e não no núcleo da célula (DAVIS et al., 2005; DAVIS; GOGLIA; LEONARD, 2015). Além disso, essas ações não são necessariamente iniciadas pelo T3, podendo também ser mediadas por T4, T2 e rT3.

A integrina de membrana $\alpha \mathrm{V} \beta 3$ é um conhecido sítio ligante para T3 e T4 envolvido nas ações não genômicas. Essa integrina possui dois domínios ligantes, S1 que tem maior afinidade por T3 e ativa a PI3K, e o S2, que tem afinidade tanto por T3 como por T4 e ativa a via da MAPK. As ações mediadas por essa integrina podem provocar o tráfico de proteínas para o núcleo e modular a expressão gênica através da fosforilação de THR $\beta_{1}$ ou de ER $\alpha_{1}$ nucleares. Além disso, THR $\beta_{1}$ e ER $\alpha_{1}$ citosólicos também podem ser fosforilados e migrarem para o núcleo quando o T4 se liga a integrina de membrana $\alpha$ V $\beta 3$ (fig. 3) (DAVIS et al., 1996; DAVIS et al., 2005; DAVIS et al., 2008). Outros sítios ligantes extranucleares do T3 são o THR $\beta_{1}$ e o TR $\Delta \alpha_{1}$ citosólicos (fig. 3).

Algumas ações não genômicas já foram demonstradas, como aumento da atividade da $\mathrm{Ca}^{2+}$-ATPASE em eritrócitos (DAVIS et al., 1986), da $\mathrm{Na}^{+}-\mathrm{K}^{+}$-ATPASE em hepatócitos (LEI; BHARGAVA; INGBAR, 2009), a estimulação da respiração mitocondrial (STERLING; BRENNER; SAKURADA, 1980). Além desses, também foram descritos efeitos como aumento da inserção da $\mathrm{Na}^{+}-\mathrm{K}^{+}$-ATPASE na membrana, aumento de atividade de PI3K e MAPK, remodelação do citoesqueleto de actina e proliferação de células de osso humanas in vitro, todos mediados por ativação de receptores extranucleares (DAVIS; GOGLIA; LEONARD, 2015; SCARLETT et al., 2008). Relatos de rápido aumento na expressão gênica de genes envolvidos com a proliferação celular mediados pela ligação de HTs com a integrina de membrana $\alpha \mathrm{V} \beta 3$ também já foram feitos (KALYANARAMAN et al., 2014; LIN et al., 2009). 


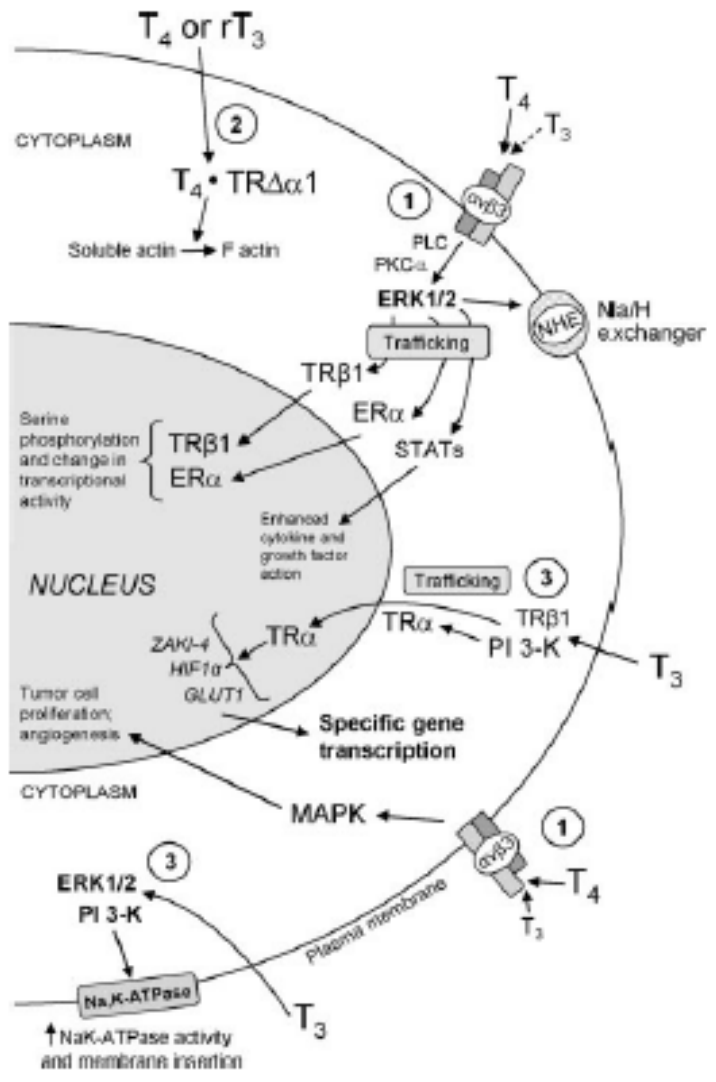

Figura 3 - Ações não genômicas do T3 iniciadas na integrina de membrana $\alpha$ V $\beta 3$ ou no citoplasma. (Retirado de Cheng, Leonard e Davis, 2010)

Algumas ações genômicas e não genômicas do T3 na hipófise foram descritas pelo nosso grupo de pesquisa. A hipófise é uma glândula localizada na base do encéfalo em uma concavidade do osso esfenoide denominada sela túrcica. A sua porção anterior é constituída por 6 tipos celulares fenotipicamente distintos, denominados corticotrofos, somatotrofos, gonadotrofos, tireotrofos, lactotrofos e somatomamotrofos (NUNES, 2008).

Silva e colaboradores (2006) demonstraram que, agudamente (30 min), o T3 aumenta tanto a síntese como a secreção de GH graças a um rearranjo do citoesqueleto de actina em hipófises de animais hipotireoideos. Foi observado também em somatotrofos que o hipotireoidismo provoca redução do recrutamento do mRNA do GH aos ribossomos e que a síntese de IGF-1 pelo fígado está prejudicada, parâmetros estes normalizados quando os ratos hipotiroideos foram tratados agudamente (30 min) com T3 (SILVA et al., 2010).

Em tireotrofos (GOULART-SILVA; DE SOUZA; NUNES, 2011) observou-se que o hipotireoidismo, induzido por tireoidectomia em ratos, provocou aumento da cauda poli(A) do 
mRNA do TSH $\beta$, aumento da sua ligação com ribossomos e citoesqueleto, sugerindo aumento da estabilidade e da taxa de tradução desse transcrito. Porém, quando estes ratos foram tratados com dose supra fisiológica de T3 por 30 minutos, ocorreu uma redução da cauda poli(A) e da ligação do transcrito do TSH $\beta$ aos ribossomos (GOULART-SILVA; DE SOUZA; NUNES, 2011), dado indicativo de que o T3 reduz a estabilidade e a tradução desse transcrito, antes mesmo de reprimir a transcrição desse gene. Em um estudo posterior em ratos hipotireoideos (Bargi-Souza et al., 2014) foi verificado que a administração de dose fisiológica de T3 (0,3 $\mu \mathrm{g} / 100 \mathrm{~g}$ ), após $30 \mathrm{~min}$, foi capaz de reduzir o conteúdo do mRNA do TSH $\beta$, bem como de aumentar a quantidade de grânulos de TSH nos tireotrofos, efeito decorrente de uma inibição da sua secreção.

Já no estudo que focou o efeito do T3 em gonadotrofos (ROMANO et al., 2013), verificou-se que o hipotireoidismo provocou um aumento na expressão do mRNA do LH, um aumento da sua cauda e uma redução do número de seus transcritos associados aos polissomos. Já o conteúdo de LH na hipófise estava reduzido, mas suas concentrações séricas estavam aumentadas em relação ao controle.

Enquanto essas ações do T3 estão bem definidas nos somatotrofos, tireotrofos e gonadotrofos, pouco se conhece sobre as mesmas em outras células hipofisárias. Por isso, nosso trabalho teve o intuito de esclarecer as ações genômicas e não genômicas do T3 nos corticotrofos, um grupamento celular de extrema importância para a sobrevivência dos seres vivos, pois regula a função das glândulas adrenais, o que será descrito a seguir.

\subsection{Eixo hipotálamo-hipófise-adrenal}

A proopiomelanocortina (POMC) é um polipeptídio precursor do ACTH. Presente em diversos tecidos, como hipófise, hipotálamo, outras regiões do sistema nervoso central e pele, a proopiomelanocortina sofre grande processamento pós-traducional. Esse processamento é tecido específico e gera, dependendo do caso, vários peptídeos envolvidos em funções biológicas diversas. POMC expressa nos corticotrofos é necessária para regulação da função adrenal, enquanto a POMC produzida em neurônios do hipotálamo exerce papel em controlar a dor e a homeostase energética. Já a produção de proopiomelanocortina na pele pode influenciar a melanogênese (RAFFIN-SANSON; KEYZER; BERTAGNA, 2003).

O hipotálamo controla a secreção hipofisária de ACTH, que é o hormônio responsável pela síntese e liberação de glicocorticóides. O principal estímulo hipotalâmico para a hipófise 
é o hormônio liberador de corticotropina (CRH), um peptídeo de 41 aminoácidos produzido no núcleo paraventricular do hipotálamo. A arginina vasopressina (AVP) é um potente potencializador da ação do CRH em estimular a secreção de ACTH, porém a AVP por si só, possui pouca atividade secretagoga de ACTH (TSIGOS; CHROUSOS, 2002).

Em situações não estressantes, tanto CRH como AVP são secretados no sistema porta de maneira circadiana, pulsátil, com uma frequência de dois a três episódios de secreção por hora. Em situação de repouso, a amplitude dos pulsos de CRH e AVP aumenta no início da manhã, resultando em picos de secreção de ACTH e cortisol na circulação. Essas variações diurnas são perturbadas por mudanças na iluminação, horários de alimentação e atividade bem como pelo estresse (TSIGOS; CHROUSOS, 2002). A amplitude dos pulsos aumenta durante o estresse agudo e nessas condições, o sistema de estresse recruta secretagogos de CRH de fontes adicionais, como os neurônios magnocelulares liberadores de AVP e a angiotensina II (CHROUSOS, 1995).

A estimulação da atividade secretória dos corticotrofos envolve a produção de AMPc e aumento na concentração de cálcio intracelular. $O$ aumento na atividade secretória é acompanhado por aumento da expressão do gene da POMC. Porém, o promotor da POMC não possui elementos responsivos ao AMPc e ao cálcio, indicando que mecanismos indiretos evoluíram para utilizar as cascatas de sinalização do AMPc e do cálcio para regular a expressão da proopiomelanocortina (JENKS, 2009). Quando no lúmen do retículo endoplasmático rugoso, a POMC segue o caminho intracelular de proteínas secretadas através do complexo de Golgi e é armazenada em grânulos de secreção, juntamente com os produtos finais do seu processamento. Tal processamento ocorre durante este tráfico, quando a molécula da POMC sofre uma série de clivagens proteolíticas pelas convertases do tipo 1 e 2 dando origem aos diversos peptídeos biologicamente ativos, como o ACTH, $\beta$-lipotrofina, $\beta$-endorfina e $\gamma$ lipotrofina (RAFFIN-SANSON; KEYZER; BERTAGNA, 2003).

O ACTH produzido nos corticotrofos é liberado na circulação e age na zona fasciculata das glândulas adrenais, onde promove o aumento da expressão de alguns genes e da atividade de enzimas envolvidas na biossíntese de corticosterona em roedores e cortisol em humanos (NICOLAIDES et al., 2015). O ACTH também age na zona glomerulosa e na zona reticularis influenciando a síntese de aldosterona e de andrógenos, respectivamente. Alguns dos genes estimulados na adrenal pelo ACTH são os da enzima StAR, CYP11A1, CYP11B1 e CYP11B2. A StAR é a enzima responsável pelo transporte de colesterol para a membrana interna da mitocôndria, CYP11A1 cliva a cadeia lateral da molécula de colesterol gerando pregnenolona, 
CYP11B1 converte 11-desoxicorticosterona em corticosterona e a CYP11B2 converte corticosterona em aldosterona na zona glomerulosa da adrenal (HANUKOGLU, 1992). Todo o processo de esteroidogênese é regulado por um receptor órfão nuclear denominado "Steroidogenic factor 1" (SF-1). Esse receptor é encontrado em todas as camadas do córtex da adrenal, nos gonadotrofos da hipófise, células de Leydig e células de Sertoli dos testículos, no hipocampo e na porção dorso medial do hipotálamo (HOIVIK, et al., 2010; PARKER; SCHIMMER, 1997). Na adrenal, o SF-1 ativa genes responsáveis pela síntese de glicocorticoides, como os genes de StAR, das hidroxilases de esteroides P450 (CYPs), da $3 \beta$ esteroide desidrogenase (3ß-HSD) e do receptor de $\mathrm{ACTH}, \mathrm{Mc} 2 \mathrm{R}$, sendo vital na regulação desse processo, já que camundongos knock-out de SF-1 na adrenal morrem nas primeiras horas de vida e não apresentam adrenais nem gônadas (CARON, et al., 1997; HOIVIK et al., 2010; LUO; IKEDA; PARKER, 1994; PARKER; SCHIMMER, 1997).

Os glicocorticoides participam da regulação do metabolismo de carboidratos, lipídeos e proteico agindo em tecidos como o fígado, músculo esquelético e tecido adiposo. Além dessas ações, atuam no sistema cardiovascular, participando do controle do tônus vascular, no sistema nervoso central, nos ossos e possuem participação importante na regulação da resposta inflamatória e imune (ELIAS et al., 2012; NICOLAIDES et al., 2015).

Alguns trabalhos relataram alterações no eixo hipotálamo-hipófise-tireóide em situações de estresse. Esta condição tem sido associada com queda na concentração plasmática de T3, T4 e TSH, sem nenhuma mudança no conteúdo de mRNA do TRH e da somatostatina. Nessa situação há evidências de um aumento da expressão do mRNA desiodase do tipo 2 central e de redução da atividade da desiodase do tipo 1 hepática (BIANCO et al., 1987; HELMREICH; TYLEE, 2011). No entanto, as alterações causadas pelo eixo hipotálamo-hipófise-tireóide no eixo hipotálamo-hipófise-adrenal ainda não foram completamente esclarecidas.

Embora em pequeno número, a literatura apresenta estudos sobre as ações do T3 no eixo hipotálamo-hipófise-adrenal de ratos. Há evidências de que no hipertireoidismo ocorre hipercorticosteronemia em ratos Sprague-Dawley (Johnson et al., 2005; Johnson et al., 2013), sem que ocorram alterações nos níveis plasmáticos de ACTH. Em outro estudo do mesmo grupo (Johnson et al., 2012) foi demonstrada uma redução da concentração de corticosterona circulante em ratos hipotiroideos. Porém esses estudos são controversos, pois apesar de relatarem alterações na corticosteronemia, eles não demonstram alterações moleculares compatíveis nos outros componentes do eixo que tem sua transcrição alterada pelo feed-back negativo exercido pela corticosterona. 
Tendo em vista a escassez e a controvérsia de dados na literatura sobre as ações genômicas e a ausência de dados sobre ações não genômicas do hormônio tireoidiano sobre os corticotrofos, propomos com este trabalho investigar as ações do T3, a curto e longo prazo, sobre a regulação da expressão e processamento da POMC, bem como as possíveis alterações no eixo hipotálamo-hipófise-adrenal.

\subsection{Objetivos}

O presente estudo teve como objetivo avaliar as ações do T3 a longo (5 dias) e/ou curto (30 minutos) prazo sobre o eixo hipotálamo-hipófise-adrenal e explorar as bases moleculares envolvidas nas mesmas. Com esse intuito realizamos experimentos in vivo utilizando ratos albinos da linhagem Wistar submetidos tireoidectomia e experimentos in vitro utilizando-se células AtT-20 (linhagem de células do corticotrofo) e cultura primária de adrenais. Além disso, verificamos ações do T3 e TSH em cultura primária de hipófise de ratos Sprague dawley. Após diversos tratamentos, foram avaliados parâmetros moleculares tais como:

(a) expressão gênica da proopiomelanocortina (POMC);

(b) comprimento de cauda poli(A) do mRNA da POMC;

(c) a taxa de tradução deste transcrito;

(d) o conteúdo de POMC e ACTH hipofisário;

(e) expressão gênica da pró-hormônio convertase do tipo 1 na hipófise;

(f) a expressão de genes responsivos ao ACTH em adrenais de ratos Wistar e em cultura primária de adrenais de ratos Sprague Dawley;

(g) dosagem sérica de ACTH e corticosterona;

(h) Secreção de ACTH em cultura primária de hipófises;

(i) Medida de AMPc em cultura primária de hipófises;

(j) Medida de cálcio citosólico em cultura primária de hipófises. 


\section{MATERIAL E MÉTODOS}

\subsection{Estudos in vivo}

Ratos albinos adultos, linhagem Wistar, foram obtidos do biotério de criação do Instituto de Ciências Biomédicas - USP. Os animais foram acondicionados no biotério de experimentação do departamento de Fisiologia e Biofísica, onde permaneceram em condições controladas de luz (ciclo claro/escuro de $12 \mathrm{~h} / 12 \mathrm{~h}$, sendo que as luzes se acendem as 6:00) e temperatura $\left(22 \pm 2{ }^{\circ} \mathrm{C}\right)$, em gaiolas coletivas. $\mathrm{O}$ regime de alimentação e ingestão hídrica foi ad libitum. Ao atingirem peso em torno de $250 \mathrm{~g}$, parte dos ratos foi submetida à remoção cirúrgica da glândula tireóide (tireoidectomia) e foram tratados com metimazol (0,03\%) - para evitar que qualquer resquício de tireoide pudesse sintetizar T3 e T4, e cloreto de cálcio $\left(\mathrm{CaCl}_{2}\right.$ - 0,05\%), já que as paratireóides dos murinos são inclusas no tecido tireoidiano e, portanto, removidas com a tireoidectomia. Após 20 dias de tireoidectomia, iniciou-se o tratamento com T3, conforme descrito a seguir.

No caso dos experimentos que avaliaram ações lentas, genômicas, do T3 (In vivo Experimento crônico), após 20 dias de tireoidectomia, os animais foram submetidos à tratamentos com diferentes doses de T3, ou salina, e divididos nos grupos descritos a seguir. Um grupo controle, constituído de animais eutireoideos, também foi adicionado ao estudo.

- Controle: animais intactos que receberam injeção de salina $(0,9 \%)$, intraperitoneal, duas vezes ao dia por cinco dias;

- Tireoidectomizado (Tx): animais tireoidectomizados que receberam injeção de salina $(0,9 \%)$, intraperitoneal, duas vezes ao dia por cinco dias;

- Tireoidectomizado + T3 dose fisiológica $(\mathbf{T x}+\mathbf{0 , 3} \mu \mathrm{g} / 100 \mathrm{~g})$ : animais tireoidectomizados que receberam injeção de T3, intraperitoneal, duas vezes ao dia por cinco dias, na concentração de $0,3 \mu \mathrm{g} / 100 \mathrm{~g}$ de peso, divididas em duas doses iguais;

- Tireoidectomizado $+\mathbf{T} 3$ dose suprafisiológica $(T \mathbf{T x}+1,5 \mu \mathrm{g} / 100 \mathrm{~g})$ : animais tireoidectomizados que receberam injeção de T3, intraperitoneal, duas vezes ao dia por cinco dias, na concentração de $1,5 \mu \mathrm{g} / 100 \mathrm{~g}$ de peso, correspondente a uma dose $5 \mathrm{X}$ maior que a fisiológica, divididas em duas doses iguais.

As injeções do tratamento foram realizadas às 8:30 e às 17:15 h. Os animais foram sacrificados entre às 9:30 e 12:00 h do dia seguinte ao término do tratamento com T3 sob o efeito de anestesia. Após o sacrifício, coletamos os corações e utilizamos o seu peso seco como 
controle para verificar a eficácia da tireoidectomia e do tratamento com T3, além dos tecidos de interesse desse estudo, que foram rapidamente congelados em $\mathrm{N}_{2}$.

No caso dos experimentos realizados para avaliar as ações rápidas, possivelmente não genômicas, do T3, (In vivo - Experimento agudo), após anestesia, os animais foram tratados, via jugular, com hormônio tireoidiano ou salina 30 minutos antes do sacrifício. Os seguintes grupos foram utilizados no estudo:

- Controle + salina: animais intactos, eutireoideos, que após anestesia receberam injeção contendo salina, 30 minutos antes do sacrifício;

- Tireoidectomizado ( $\mathbf{T x}$ + salina): animais tireoidectomizados que, após anestesia, receberam injeção de salina $(0,9 \%)$, intravenosa, 30 minutos antes do sacrifício;

- Tireoidectomizado + T3 dose fisiológica $(\mathbf{T x}+\mathbf{0 , 3} \mu \mathrm{g} / 100 \mathrm{~g})$ : animais tireoidectomizados que, após anestesia, receberam injeção de triiodotironina na dose fisiológica $(0,3 \mu \mathrm{g} / 100 \mathrm{~g}$ de peso corporal), intravenosa, 30 minutos antes do sacrifício;

- Tireoidectomizado + T3 dose suprafisiológica $(T \mathbf{T x}+100 \mu \mathrm{g} / 100 \mathrm{~g})$ : animais tireoidectomizados que após anestesia receberam injeção de triiodotironina na dose de $100 \mu \mathrm{g} /$ $100 \mathrm{~g}$ de peso corporal, intravenosa, 30 minutos antes do sacrifício;

No dia do sacrifício, os animais foram anestesiados por injeção intraperitoneal de cloridrato de ketamina e cloridrato de xilazina, na proporção de $1 / 1$ e na dose de $0,1 \mathrm{ml} / 100 \mathrm{~g}$ de peso. Após o fim do tratamento de $30 \mathrm{~min}$, os ratos foram decapitados e os tecidos foram coletados e imediatamente congelados em nitrogênio líquido para posterior processamento. A coleta foi realizada entre as 9:30 e as 12:00 h. Além da hipófise, alvo principal deste estudo, coletamos também o hipotálamo e adrenais, para análises que serão descritas oportunamente.

\subsection{Estudos In vitro}

\subsubsection{Preparo de Soro Fetal Bovino e Soro de Cavalo com resina Ag1-X8}

O soro fetal bovino (SFB) e o soro de cavalo utilizados em parte dos estudos in vitro foram tratados com a resina Ag1-X8 (Biorad). O tratamento com essa resina remove alguns componentes do SFB, incluindo os hormônios tireoidianos T3 e T4, tornando-o interessante para o nosso objetivo de verificar ações do T3 in vitro.

Primeiramente, a resina foi pesada em quantidade suficiente para a quantidade de soro tratado $(2,5 \mathrm{~g} / 50 \mathrm{~mL}$ de soro). Essa resina foi hidratada em água ultrapura, agitada por 10 
minutos em gangorra e centrifugada a 2500 g para separação da resina e água. A água foi removida, água ultrapura foi novamente adicionada e o processo foi repetido mais duas vezes. O soro foi adicionado após esse processo, permaneceu durante toda a noite sob agitação e na manhã seguinte foi filtrado e congelado em alíquotas.

\subsubsection{Cultura primária de hipófises}

Ratos da linhagem Sprague Dawley com idade entre 60 e 65 dias obtidos na Taconic Farms (Germantown, NY) foram utilizados nos protocolos de cultura primária. A eutanásia foi realizada em câmara de $\mathrm{CO}_{2}$ e as hipófises foram rapidamente removidas, a neurohipófise retirada e as glândulas foram transferidas para meio 199 contendo HEPES. As hipófises foram então lavadas em PBS contendo BSA 0,3\%, glutamina $2 \mathrm{mM}$ e $\mathrm{CaCl}_{2} 1,25 \mathrm{mM}$ e vitaminas MEM (Invitrogen) para remoção do sangue. Após a lavagem, as glândulas foram cortadas no aparelho Chopper (Brinkmann Instruments, Westbury, NY). Em seguida, o tecido foi lavado novamente e transferido para um tubo cônico contendo tripsina $0,4 \%$ e agitado a $120 \mathrm{rpm}$ em banho maria a $37^{\circ} \mathrm{C}$ por 15 min. Após a agitação adicionou-se DNAse para precipitação do tecido e, subsequentemente a precipitação, a solução foi descartada e inibidor de tripsina (2,6 $\mathrm{mg} / \mathrm{mL}$ ) dissolvido em PBS foi adicionado. Novamente agitou-se o tubo em banho maria por 5 min, o inibidor de tripsina foi descartado e adicionou-se PBS contendo BSA 0,3\%, glutamina $2 \mathrm{mM}$, EDTA $2 \mathrm{mM}$ e vitaminas MEM (Invitrogen). As células foram agitadas em banho maria por mais 5 min, descartou-se a solução e a substituímos por uma solução semelhante, porém com EDTA $1 \mathrm{mM}$ e novamente agitou-se o tubo a $120 \mathrm{rpm}, 37^{\circ} \mathrm{C}$ por $10 \mathrm{~min}$. Após descarte da solução contendo EDTA, o tecido foi dissociado mecanicamente em PBS contendo BSA $0,3 \%$, glutamina $2 \mathrm{mM}$ e vitaminas MEM. Após a dissociação, as células foram contadas em câmara de Neubauer e plaqueadas em diferentes densidades em placas ou lamínulas revestidas com poli-L-lisina utilizando-se meio 199 acrescido de soro de cavalo 10\%. Seguem as densidades utilizadas para cada protocolo:

- 0,25 milhão de células em cada poço para os ensaios de secreção estática e AMPc;

- 12 milhões de células por câmara para o ensaio de perifusão;

- 0,5 milhão de células em cada lamínula para os ensaios de concentração de cálcio citosólico. 


\subsubsection{Secreção estática em cultura primária de hipófise}

No dia seguinte ao plaqueamento das células, os respectivos grupos foram estudados no ensaio de cultura estática onde houve tratamento com o hormônio triiodotironina (T3):

- Controle: Células hipofisárias foram tratadas com meio 199 acrescido de soro de cavalo $(10 \%)$ por 1 e $4 \mathrm{~h}$.

- Resina: Células hipofisárias foram tratadas com meio 199 acrescido de soro de cavalo (10\%) tratado com resina por 1 e $4 \mathrm{~h}$.

- Resina $+\mathbf{T}_{3} \mathbf{1 0}^{-7} \mathbf{M}$ : Células hipofisárias foram tratadas com meio 199 acrescido de soro de cavalo (10\%) tratado com resina e T3 na concentração $10^{-7} \mathrm{M}$ por 1 e $4 \mathrm{~h}$.

- Resina $+\mathbf{T}_{3} \mathbf{1 0}^{-9}$ M: Células hipofisárias foram tratadas com meio 199 acrescido de soro de cavalo (10\%) tratado com resina e T3 na concentração $10^{-9} \mathrm{M}$ por 1 e $4 \mathrm{~h}$.

- Resina + CRH 30 pM: Células hipofisárias foram tratadas com meio 199 acrescido de soro de cavalo (10\%) tratado com resina e CRH 30 pM por 1 e $4 \mathrm{~h}$.

Os seguintes tratamentos foram realizados no ensaio de cultura estática onde houve tratamento com os hormônios TRH e TSH:

- Controle: Células hipofisárias foram tratadas com meio 199 acrescido de BSA 0,1\% por 2, 7 e $19 \mathrm{~h}$;

- TRH: Células hipofisárias foram tratadas com meio 199 acrescido de BSA 0,1\% e TRH 10 $\mathrm{nM}$ foi aplicado por 2, 7 e $19 \mathrm{~h}$;

- TSH: Células hipofisárias foram tratadas com meio 199 acrescido de BSA 0,1\% e TSH $1 \mathrm{mU} / \mathrm{mL}$ foi aplicado por $2,7 \mathrm{e} 19 \mathrm{~h}$;

- TRH+TSH: Células hipofisárias foram tratadas com meio 199 acrescido de BSA 0,1\% e TRH $10 \mathrm{nM}$ e TSH $1 \mathrm{mU} / \mathrm{mL}$ foram aplicados por 2, 7 e $19 \mathrm{~h}$.

\subsubsection{Perifusão de células hipofisárias}

Após o processo de dissociação das células hipofisárias, 12 milhões de células foram depositadas em cada placa de petri de $60 \mathrm{~mm}$ sem tratamento para adesão de células. Foram adicionadas a estas células $300 \mu \mathrm{L}$ de beads Cytodex (Sigma) com 131-220 $\mu \mathrm{m}$ de diâmetro, $4,2 \mathrm{~mL}$ de meio 199 e $500 \mu \mathrm{L}$ de soro de cavalo, nesta ordem. As placas foram mantidas na 
incubadora a $37^{\circ} \mathrm{C}$ e com atmosfera contendo $5 \%$ de $\mathrm{CO}_{2}$ por dois dias para as células aderirem as beads. Após os dois dias de incubação, as células foram transferidas para câmaras e foram perifundidas com meio 199 mantido a $37^{\circ} \mathrm{C}$ contendo sais de Hanks, HEPES 25 mM, BSA $0,1 \%$ e antibióticos por 2 horas num fluxo de $0,2 \mathrm{~mL} / \mathrm{min}$ para estabilizar a secreção de hormônios. Após este período, a velocidade de fluxo do meio foi aumentada para $0,6 \mathrm{~mL} / \mathrm{min}$ e os tratamentos foram iniciados com coletas a cada dois minutos.

Para o ensaio de perifusão de células hipofisárias, dois tratamentos foram utilizados:

- Controle: Células hipofisárias aderidas a beads foram perifundidas com meio 199 acrescido de BSA $0,1 \%$ por $80 \mathrm{~min}$;

- TSH: Células hipofisárias aderidas a beads foram perifundidas com meio 199 acrescido de BSA $0,1 \%$ e TSH na concentração de $1 \mathrm{mU} / \mathrm{mL}$ por $80 \mathrm{~min}$.

As alíquotas após coletadas foram colocadas em gelo até o término do experimento e congeladas a $-20{ }^{\circ} \mathrm{C}$ para posterior dosagem de ACTH.

\subsubsection{Medida da concentração de 3'5'-adenosina-monofosfato-cíclico (AMPc) intracelular e no meio de cultura}

A produção de AMPc foi medida em cultura estática de hipófises por radioimunoensaio (RIA). As células foram plaqueadas em placas de 24 poços numa densidade de 0,25 milhões de células por poço. No dia seguinte ao plaqueamento, os seguintes tratamentos foram realizados:

- Controle: Células de hipófise em cultura estática foram tratadas com meio 199 acrescido de BSA 0,1\% e 3-isobutil-1-metilxantina (IBMX, SIGMA) 1mM por 0, 1, 2, 4 e 6 h;

- TSH: Células de hipófise em cultura estática foram tratadas com meio 199 acrescido de BSA 0,1\%, TSH 1mU/mL e 3-isobutil-1-metilxantina (IBMX, SIGMA) $1 \mathrm{mM}$ por 0, 1, 2, 4 e $6 \mathrm{~h}$;

Após os tempos mencionados acima, as células e meio de cultura foram rapidamente coletados e congelados em gelo seco. O AMPc foi medido no meio de cultura e nas células por RIA utilizando-se anticorpo fornecido por Albert Baukal (NICHD, Bethesda). O traçador utilizado, ${ }^{125}$ I-cAMP, foi adquirido na empresa PerkinElmer Life Sciences (Boston, MA). 


\subsubsection{Medida de cálcio citosólico}

As medidas de cálcio intracelular foram realizadas utilizando-se microscopia de fluorescência. As células foram plaqueadas em lamínulas de $25 \mathrm{~mm}$ tratadas com poli-L-lisina e as placas permaneceram por 2 a 3 dias na incubadora. Após este tempo as células foram incubadas com meio Krebs-Ringer contendo 2,5 $\mu \mathrm{M}$ fura 2-AM por 1 hora. As lamínulas foram lavadas com meio Krebs-Ringer e montadas no microscópio invertido Observer-D1 (Carl Zeiss) acoplado a uma câmera ORCA-ER (Hamamatsu Photonics) e a um trocador de comprimento de onda Lambda DG-4 (Sutter). O controle dos equipamentos e a análise das imagens foram realizadas pelo software Metafluor (Molecular Devices). Os experimentos foram realizados utilizando-se uma objetiva com aumento de 40 x em óleo de imersão, enquanto as células foram expostas a feixes de luz com comprimento de onda alternado entre 340 e $380 \mathrm{~nm}$ e a intensidade da emissão de luz a $520 \mathrm{~nm}$ foi medida. Mudanças na concentração de cálcio intracelular foram medidas pela razão entre a intensidade de fluorescência $F_{340} / F_{380}$. Corticotrofos foram identificados através da resposta das células a estimulação por CRH e AVP.

\subsubsection{Células AtT-20}

Nestes estudos foram utilizadas células corticotróficas da linhagem tumoral AtT-20 obtidas a partir de camundongos. As células AtT-20 foram geradas a partir de tumores de hipófise de camundongo explantados, cultivados e injetados em camundongos para se obter novos tumores. Os tumores foram então novamente explantados, a sua atividade hormonal foi testada e esse processo repetiu-se por diversas vezes com o intuito de ocorrer a seleção de células mais adaptadas as condições de cultivo in vitro com capacidade de crescimento e atividade hormonal aumentadas (BUONASSI; SATO; COHEN, 1962). Diversos trabalhos já caracterizaram suas propriedades, como a presença de grânulos secretórios contendo ACTH e ß-lipotropina (GUMBINER; KELLY, 1981), a sua capacidade de transportar glicocorticoides para dentro da célula (HARRISON; SATO; COHEN, 1975) e até mesmo de responder rapidamente aos mesmos (WOODS et al., 2002). As células utilizadas neste experimento foram gentilmente cedidas na passagem 8 pelo prof. Dr. Emer Suavinho Ferro, do ICB-USP.

As células AtT-20 foram plaqueadas em meio DMEM (Vitrocell, Campinas, São Paulo) contendo $10 \%$ de soro fetal bovino, $100 \mathrm{U} / \mathrm{mL}$ de penicilina e $0,1 \mathrm{mg} / \mathrm{mL}$ de estreptomicina 
(Sigma Chemical Co). As células foram mantidas em estufa a $37{ }^{\circ} \mathrm{C}$ num ambiente com $5 \%$ de $\mathrm{CO}_{2}$. Um dia antes do experimento, parte das células receberam meio DMEM contendo 10\% de soro fetal bovino depletado de hormônio tireoidiano, após o tratamento do soro com resina AG1X-8 (Bio-Rad Laboratories, CA), constituindo o grupo hipotireoideo, enquanto outra parte das células recebeu meio controle (soro não depletado para os hormônios tireoidianos). As células que constituíram o grupo hipotireoideo foram, a seguir, tratadas com T3, na presença ou não de drogas específicas, cujas ações serão descritas oportunamente.

Antes do início dos estudos propriamente ditos, foram realizados experimentos para padronização de tempo em que manteríamos as células no meio depletado de hormônio tireoidiano, e testes de concentração de hormônio tireoidiano a serem utilizadas nos experimentos subsequentes. Selecionamos o tempo de $24 \mathrm{~h}$ de manutenção das células em meio depletado de hormônio tireoidiano, por ser aquele em que houve a maior queda de expressão gênica da POMC entre os tempos avaliados (12 a 72 h), resultado esse esperado já que nossos animais tireoidectomizados também apresentaram redução no conteúdo de mRNA da POMC. Em relação à concentração de T3, optamos pela utilização da concentração $10^{-9} \mathrm{M}$ de $\mathrm{T} 3$ dentre as demais utilizadas $\left(10^{-10} \mathrm{M}\right.$ a $\left.10^{-7} \mathrm{M}\right)$ por ser a dose que provocou o aumento de expressão gênica a valores iguais aos do grupo controle e elegemos a dose $10^{-7} \mathrm{M}$ como a dose supra fisiológica para as células AtT-20.

Além disso, realizamos teste das células em citômetro de fluxo para verificar se a utilização do soro tratado com resina por 24 h não estaria afetando a viabilidade celular. Nesse teste, as células foram tripsinizadas, ressuspendidas em meio DMEM e incubadas com iodeto de propídio $(50 \mu \mathrm{g} / \mathrm{mL})$ por $5 \mathrm{~min}$. O iodeto de propídio é um composto fluorescente que não é capaz de atravessar a membrana de células intactas. Se existe algum dano na membrana, o iodeto de propídio adentra a célula e se intercala no DNA. Após a incubação, as células foram avaliadas no citômetro de fluxo FACScalibur (Becton Dickinson, San Juan, CA, USA) e no software Cell Quest (Becton Dickinson). O equipamento avaliou as células vivas e mortas e a fluorescência foi medida pelo canal FL2 (585/42 nm).

Após a padronização do estudo, partimos para os seguintes experimentos:

\subsubsection{Efeito do tratamento com T3 sobre a expressão gênica da proopiomelanocortina na presença do bloqueador de transcrição gênica actinomicina $D$}


As ações rápidas do T3, possivelmente não genômicas, foram avaliadas através do tratamento, ou não, de células AtT-20 com actinomicina D (conhecido bloqueador da transcrição gênica), por $150 \mathrm{~min}$, antes do T3 ser adicionado ao meio de cultura. As células foram divididas nos seguintes grupos:

- Controle (C): células AtT-20 mantidas em meio DMEM acrescido de soro fetal bovino (10\%) e submetidas $(+)$ ou não (-) ao tratamento com actinomicina D.

- Hipotiroideo (Hipo): células AtT-20 mantidas em meio DMEM acrescido de soro fetal bovino (10\%) depletado de hormônio tireoidiano por 24 horas, submetidas (+) ou não (-) ao tratamento com actinomicina D.

- Hipotiroideo + T3 dose $10^{-9}$ M (10 $\left.{ }^{-9} \mathbf{M}\right)$ : células AtT-20 mantidas em meio DMEM depletado de hormônio tireoidiano por 24 horas, submetidas (+) ou não (-) ao tratamento com actinomicina $\mathrm{D}$, e a seguir tratadas por $30 \mathrm{~min}$ com $\mathrm{T} 3$ na dose $10^{-9} \mathrm{M}$.

- Hipotiroideo + T3 dose 10 $^{-7} \mathbf{M}\left(\mathbf{1 0}^{-7} \mathbf{M}\right)$ : células AtT-20 mantidas em meio DMEM depletado de hormônio tireoidiano por 24 horas, submetidas (+) ou não (-) ao tratamento com actinomicina $\mathrm{D}$, e a seguir tratadas por $30 \mathrm{~min}$ com $\mathrm{T} 3$ na dose $10^{-7} \mathrm{M}$.

2.2.9 Efeito do T3 sobre a expressão gênica da proopiomelanocortina na presença de bloqueador sítio de ligação à integrina de membrana $\alpha V \beta 3$

Para verificar se as ações rápidas do $T_{3}$ eram mediadas pela integrina de membrana $\alpha \mathrm{V} \beta 3$, utilizamos hexapeptídeos contendo os domínios RGD (arginina, glicina e aspartato) e RGE (arginina, glicina e glutamato). $\mathrm{O}$ RGD se liga à integrina de membrana $\alpha \mathrm{V} \beta 3$ em um sítio que reconhece o domínio RGD das proteínas de matriz extracelular, bem como o T3, bloqueando assim as possíveis interações que o T3 possa ter com esse sítio, sendo possível, dessa maneira, identificar se existem ações provocadas pelo T3 por meio desta integrina. $\mathrm{O}$ RGE, por possuir um glutamato no lugar do ácido aspártico, não exerce ação de bloqueio da integrina, sendo utilizado como um controle negativo do experimento. Verificamos também por qPCR que as células AtT-20 expressam o mRNA das duas subunidades da integrina de membrana $\alpha \mathrm{V} \beta 3$.

Os seguintes grupos experimentais foram utilizados no estudo:

- Controle (Controle): células AtT-20 mantidas em meio DMEM acrescido de soro fetal bovino $(10 \%)$. 
- Hipotiroideo (Hipo): células AtT-20 mantidas em meio DMEM acrescido de soro fetal bovino (10\%) depletado de hormônio tireoidiano por $24 \mathrm{~h}$.

- Hipotiroideo + T3 dose 10 $^{-9}$ M (Hipo+T3): células AtT-20 mantidas em meio DMEM depletado de hormônio tireoidiano por $24 \mathrm{~h}$ e tratadas com T3 na dose $10^{-9} \mathrm{M}$ por $30 \mathrm{~min}$.

- Hipotiroideo + RGD + T3 dose 10 $^{-9}$ M (Hipo+RGD+T3): células AtT-20 mantidas em meio DMEM depletado de hormônio tireoidiano por $24 \mathrm{~h}$ e então submetidas ao tratamento com RGD, na concentração de $100 \mu \mathrm{g} / \mathrm{ml}$, por $30 \mathrm{~min}$. Após este período, as células foram tratadas com $\mathrm{T} 3$ na dose $10^{-9} \mathrm{M}$, por $30 \mathrm{~min}$.

- Hipotiroideo + RGE + T3 dose 10 ${ }^{-9}$ M (Hipo+RGE+T3): células AtT-20 mantidas em meio DMEM depletado de hormônio tireoidiano por $24 \mathrm{~h}$ e então submetidas ao tratamento com RGE, na concentração de $100 \mu \mathrm{g} / \mathrm{ml}$, por $30 \mathrm{~min}$. Após esse período, as células foram tratadas com T3 na dose $10^{-9} \mathrm{M}$, por $30 \mathrm{~min}$.

- Hipotiroideo + RGD (Hipo+RGD): células AtT-20 mantidas em meio DMEM depletado de hormônio tireoidiano por 24 h e então submetidas ao tratamento com RGD, na concentração de $100 \mu \mathrm{g} / \mathrm{ml}$, por $30 \mathrm{~min}$.

\subsubsection{Cultura primária da glândula adrenal}

As adrenais de ratos Sprague Dawley com idade de 60 dias foram utilizadas para a técnica de cultura primária. Todo material utilizado durante os procedimentos era estéril. Os animais foram rapidamente eutanaziados por decapitação e suas adrenais foram removidas e mantidas em meio DMEM (GIBCO, Thermo Scientific, EUA) até o término da coleta. As glândulas foram transferidas para placas de petri contendo PBSA e foram lavadas três vezes, onde cada lavagem foi realizada em uma nova placa. Posteriormente, as glândulas foram transferidas para uma placa contendo DMEM, a gordura foi removida, o tecido foi picotado manualmente e transferido para um frasco com colagenase $(0.002 \mathrm{~g} / \mathrm{ml} / \mathrm{adrenal})$ onde foram mantidas por 30 min a $37^{\circ} \mathrm{C}$. Em seguida o tecido foi ressuspendido várias vezes até sua completa dissociação e as células foram transferidas para um tubo cônico com um filtro de células acoplado $(100 \mu \mathrm{m})$ e centrifugadas a $1000 \mathrm{rpm}$ por $10 \mathrm{~min}$. A etapa de centrifugação foi repetida mais duas vezes para eliminar células sanguíneas. Posteriormente, as células foram ressuspendidas em DMEM contendo soro fetal bovino (10\%) e plaqueadas em placas de 12 poços (TPP, Suíça). No segundo dia após o plaqueamento o meio de cultura foi trocado e os seguintes tratamentos foram realizados: 
- Controle: células dissociadas de adrenal mantidas em meio DMEM acrescido de soro fetal bovino (10\%) por $28 \mathrm{~h}$;

- SFB (0,5\%): células dissociadas de adrenal mantidas em meio DMEM acrescido de soro fetal bovino $(0,5 \%)$ por $28 \mathrm{~h}$;

- SFB (0,5\%) + $\mathbf{T}_{\mathbf{3}} \mathbf{1 0}^{-7} \mathrm{M}$ : células dissociadas de adrenal mantidas em meio DMEM acrescido de soro fetal bovino $(0,5 \%)$ por $24 \mathrm{~h}$ e em seguida tratadas com T3 na concentração $10^{-7} \mathrm{M}$ por $4 \mathrm{~h}$;

- SFB (0,5\%) + $\mathbf{T}_{\mathbf{3}} \mathbf{1 0}^{-9} \mathrm{M}$ : células dissociadas de adrenal mantidas em meio DMEM acrescido de soro fetal bovino $(0,5 \%)$ por $24 \mathrm{~h}$ e em seguida tratadas com T3 na concentração $10^{-9} \mathrm{M}$ por $4 \mathrm{~h}$.

Após o término do tratamento, solução D foi adicionada as placas e as mesmas foram congeladas a $-80{ }^{\circ} \mathrm{C}$ para futura extração de RNA.

O tratamento de cultura primária de adrenal com SFB na concentração de 0,5\% para sensibilização da cultura primária a tratamentos já foi estudado (MATTOS; LOTFI, 2005). Neste trabalho as pesquisadoras concluíram que essas células podem ser tratadas por até $72 \mathrm{~h}$ com essa concentração de soro sem que haja perda de viabilidade celular.

Após os tratamentos descritos nas seções acima, as células e o meio de cultura dos experimentos in vitro e os tecidos coletados nos experimentos in vivo foram utilizados para as avaliações descritas a seguir.

\subsection{Avaliação da expressão gênica}

O RNA total foi extraído pelo método da guanidina-fenol-clorofórmio (CHOMCZYNSKI; SACCI, 1987). Todos os tecidos e células foram homegeneizados em 500 $\mu \mathrm{L}$ de solução D (4 M isotiocianato de guanidina, $25 \mathrm{mM}$ citrato de sódio $\mathrm{pH}$ 7,0, 0,5\% lauril sarcosinato de sódio, 0,1 M de 2-mercaptoetanol).

Após a homogeneização foram acrescentados $500 \mathrm{uL}$ de fenol saturado e os microtubos foram submetidos a agitação; 200 uL de clorofórmio foram então adicionados e as amostras foram novamente agitadas. Após estes procedimentos, as amostras permaneceram 15 minutos no gelo e foram centrifugadas a $10.000 \mathrm{~g}$, por $20 \mathrm{~min}$, a $4{ }^{\circ} \mathrm{C}$. Três fases então se formaram, denominadas aquosa, intermediária e inferior. A fase aquosa, onde está presente o RNA, foi 
transferida para um novo eppendorf. Na próxima etapa (precipitação do RNA) adicionou-se 0,5 $\mathrm{mL}$ de álcool isopropanol às amostras e as mesmas foram incubadas por 10 minutos à temperatura ambiente. A seguir, foi realizada a centrifugação a $12.000 \mathrm{~g}$ por 10 minutos a $4^{\circ} \mathrm{C}$ e um pellet de RNA foi formado. Após remoção do sobrenadante, $0,5 \mathrm{~mL}$ de álcool $75 \%$ gelado foi adicionado para lavagem do pellet. Uma nova centrifugação a $10.000 \mathrm{~g}$ foi realizada e o sobrenadante desprezado. O pellet foi seco no Speed Vack, por 5 minutos, e o RNA foi ressuspendido em água $\mathrm{DEPC}$ sob aquecimento a $65^{\circ} \mathrm{C}$, por $10 \mathrm{~min}$.

A integridade do RNA foi confirmada pela visualização das bandas do RNA ribossomal $28 \mathrm{~S}$ e $18 \mathrm{~S}$, no transiluminador, após eletroforese de 1 ug de RNA total em gel de agarose (1\%), corado com GelRed.

O RNA obtido foi submetido ao ensaio de transcrição reversa, utilizando a enzima MMLV Reverse Transcriptase (50,000U; Promega ${ }^{\circledR}$, EUA). Primeiramente, 1 ug de RNA juntamente com 1uL de oligo dT e água DEPC, que foi adicionada até se atingir um volume de $12 \mathrm{uL}$, foram aquecidos por 10 minutos a $65^{\circ} \mathrm{C}$. Na segunda etapa, os tubos foram retirados do aquecimento e colocado em gelo por 2 minutos. Então, uma mistura com volume total de $8 \mathrm{uL}$ contendo a enzima M-MLV, seu tampão específico, dNTP mix e água DPEC foi adicionada às amostras. Esta nova mistura foi aquecida a $42{ }^{\circ} \mathrm{C}$ durante 60 minutos e depois a $70{ }^{\circ} \mathrm{C}$, por 10 minutos, para inativação da enzima.

Posteriormente foi realizado o PCR quantitativo, em tempo real (qPCR), com primer específico para a sequência dos genes de interesse estudados e para os genes constitutivos RPL19 e ciclofilina. Todos os primers utilizados (tabela 1) tiveram seu tamanho de fragmento e eficiência verificados antes do uso nos experimentos. Foram utilizados 100 nanogramas de cDNA para os experimentos in vitro e 10 nanogramas para os experimentos in vivo. O protocolo de ciclagem no aparelho (Rotor gene - Qiagen) foi programado de acordo com o sugerido pelo protocolo estabelecido para a enzima utilizada, a GoTaq MasterMix - Promega. Numa primeira etapa, as amostras foram aquecidas a $95{ }^{\circ} \mathrm{C}$ por dois minutos para ativação da enzima. Em seguida iniciou-se uma segunda etapa composta por 40 ciclos, onde primeiramente ocorre um aquecimento a $95^{\circ} \mathrm{C}$ por 15 segundos para desnaturação das fitas e, em seguida, a temperatura é reduzida para $60^{\circ}$ por 60 segundos para que ocorram o anelamento e a extensão da fita. $\mathrm{O}$ terceiro passo consiste na dissociação (melting), onde a temperatura sobe gradualmente de $60^{\circ}$ até $95^{\circ} \mathrm{C}$. Os primers utilizados apresentaram somente um pico de melting. 
Tabela 1 - Primers utilizados para ensaio de qPCR

\begin{tabular}{|c|c|}
\hline POMC & $\begin{array}{l}\text { S 5' - CAAGGACAAGCGCTACGG - 3' } \\
\text { AS 5' - CTCACTGGCCCTTCTTGTG - 3' }\end{array}$ \\
\hline \multirow{2}{*}{$\mathrm{CRH}$} & S 5' - CTCTCTGGATCTCACCTTCCAC - 3' \\
\hline & AS 5' - CTAAATGCAGAATCGTTTTGGC - 3' \\
\hline \multirow{2}{*}{ PC $1 / 3$} & S 5' - AGCAAAGAGGTTGGACTCTGC - 3' \\
\hline & AS 5' - TATGAAGAGCACTTCTTCGGG - 3' \\
\hline \multirow{2}{*}{ StAR } & S 5' - CTGGCAGGCATGGCCACACA - 3' \\
\hline & AS 5' - GGCAGCCACCCCTTGAGGTC - 3' \\
\hline \multirow{2}{*}{ CYP11B1 } & S 5' - GTCTATAAACATTCAGTCCAA - 3' \\
\hline & AS 5' - ATCTCGGATATGACACTCC - 3' \\
\hline \multirow{2}{*}{ CYP11B2 } & S 5' - GGATGTCCAGCAAAGTCTC - 3' \\
\hline & AS 5' - ATTAGTGCTGCCACAATGC - 3' \\
\hline \multirow{2}{*}{ RPL 19} & S 5'- CAATGAAACCAACGAAATCG - 3' \\
\hline & AS 5'- TCAGGCCATCTTTGATCAGCT - 3' \\
\hline \multirow{2}{*}{ Ciclofilina } & S 5' - GGATTCATGTGCCAGGGTGG - 3' \\
\hline & AS 5' - CACATGCTTGCCATCCAGCC - 3' \\
\hline \multirow{2}{*}{ CYP11A1 } & S 5' - CAACATGGAGTCAGTTTACA - 3' \\
\hline & AS 5' - GACCCTCGCAGGAGAAGAGA - 3' \\
\hline \multirow{2}{*}{ HSD3B } & S 5' - GACAGGAGCAGGAGGGTTTGTGG - 3' \\
\hline & AS 5' - CTCCTTCTAACATTGTCACCTTGGCCT - 3' \\
\hline \multirow{2}{*}{ SF-1 } & S 5' - CGCCAGGAGTTTGTCTGTCT - 3' \\
\hline & AS 5' - ACCTCCACCAGGCACAATAG - 3' \\
\hline \multirow{2}{*}{$\mathrm{Mc} 2 \mathrm{R}$} & S 5' - ATCTGCAGTTTGGCCATTTC - 3' \\
\hline & AS 5' - GCAATCACAGACAGGCTGAA - 3' \\
\hline
\end{tabular}

Os ensaios de expressão dos genes do receptor de TSH, POMC e da constitutiva GAPDH utilizados na avaliação de cultura primária de hipófise foram realizados no National Institutes of Health (NIH, Bethesda). Para estas amostras utilizamos procedimentos diferentes dos acima citados. A extração de RNA foi feita utilizando-se o kit RNeasy (Qiagen, EUA), seguindo o protocolo do produto e o RNA obtido das amostras foi quantificado no aparelho Nanodrop (Thermo Scientific, EUA). A transcrição reversa foi feita com $1 \mu \mathrm{g}$ de RNA e o kit "Transcriptor First Strand cDNA Synthesis Kit" (ROCHE Applied Science) de acordo com as informações fornecidas no manual. Diferentemente dos experimentos realizados no Brasil, foi utilizada a tecnologia Taqman para amplificação dos genes de interesse. As sondas foram 
adquiridas da Applied Biosystems, TSHr (FAM-MGB - Rn00563612_m1), POMC (FAMMGB - Rn00595020_m1) e GAPDH (FAM-MGB - Rn01775763_g1) e o kit "LightCycler TaqMan master mix" (ROCHE Applied Science) foi utilizado para amplificação no PCR em tempo real. O mix para amplificação foi constituído por $3,4 \mu \mathrm{L}$ de água ultra pura, $1,2 \mu \mathrm{L}$ de enzima e $0,4 \mu \mathrm{L}$ da sonda desejada, adicionando-se $1 \mu \mathrm{L}$ de amostra a essas quantidades. As amostras foram submetidas a amplificação no aparelho Light Cycler 2.0 (ROCHE Applied Science).

\subsection{Avaliação do grau de adenilação do mRNA da POMC por RACE-PAT: Rapid Amplification of cDNA Ends - Poly A Test}

Após a extração de RNA total, uma alíquota das amostras foi utilizada para o ensaio do estado de adenilação do mRNA da POMC através do método RACE-PAT, descrito por SALLÉS e colaboradores (1999). Os smears dos produtos amplificados por PCR foram analisados em gel de agarose 2,5\% com EtBr através do uso do Software Imagequant (GE Healthcare Life Sciences), e o comprimento da cauda poli-A foi estimado de acordo com o tamanho do smear observado para cada grupo amostral, conforme descrito por SALLÉS (1999). Para confirmar o tamanho esperado do fragmento mínimo foi usado o marcador DNA ladder (100 Kb Plus Invitrogen Life Technologies, Carlsbad, CA, USA).

\subsection{Perfil polissomal}

Essa análise permite avaliar o conteúdo de transcrito que está sendo traduzido em proteínas no exato momento do estudo.

Um pool de 10 hipófises foi homogeneizado em 0,6 mL de tampão de lise (Tris-HCl 15 mM, pH 7.4; $\mathrm{MgCl}_{2} 25$ mM; $\mathrm{NaCl} 300$ mM; Triton X-100 1\%; ciclohexamida 0,1 mg/ml; ditiotreitol $1 \mathrm{mM}$ e heparina $10 \mathrm{mg} / \mathrm{ml}$ ). Após a homogeneização, as amostras foram centrifugadas a $10.000 \mathrm{~g}$ por $10 \mathrm{~min}$ a $4{ }^{\circ} \mathrm{C}$ para retirada dos debris celulares e a concentração de ácidos nucleicos do sobrenadante foi quantificada. As amostras foram então depositadas sobre um gradiente de sacarose (7-47\%) montado em um tubo, que foi centrifugado a aproximadamente 114.000 g por 150 min (SW41 Ti rotor, Beckmann). Após centrifugação, as amostras foram coletadas, suas absorbâncias analisadas em comprimento de onda UV de 254 
nm (Monitor UVis-920; GE HealthcareBio-Sciences AB, Uppsala, Sweden), e em seguida foram aliquotadas em 11 frações de aproximadamente $1 \mathrm{~mL}$ cada, que foram congeladas a -80 ${ }^{\circ} \mathrm{C}$. As frações de 6 a 11 corresponderam às polissomais. O RNA foi então extraído dessas frações e submetido aos passos citados anteriormente para verificação da expressão gênica.

\subsection{Western blotting POMC/ACTH}

A metodologia de Western blotting foi utilizada para análise do conteúdo proteico de POMC e ACTH. Cada hipófise foi homogeneizada em $300 \mu \mathrm{L}$ de tampão RIPA (Tris $50 \mathrm{mM}$ pH 8,0; NaCl 150 mM; SDS 0,1\%; NP-40 1\%; Deoxicolato 12 mM). Após a homogeneização, as amostras foram centrifugadas a $1000 \mathrm{~g}$ e o sobrenadante foi coletado para quantificação proteica pelo método de Bradford (Bio-Rad Laboratories, Inc). Uma parte do sobrenadante foi diluída 10 vezes e $6 \mu \mathrm{L}$ foram plotados em placas de ELISA de fundo chato onde $300 \mu \mathrm{L}$ de Bradford foram posteriormente adicionados. A reação foi mantida no escuro por 10 min e, logo em seguida, a absorbância foi lida no espectro de onda de $595 \mathrm{~nm}$ no aparelho de espectrofotometria Epock (Bio-tek Instruments). Após a quantificação, as amostras foram aliquotadas em tampão Laemmli e aquecidas a $70{ }^{\circ} \mathrm{C}$ por $10 \mathrm{~min}$. Após o aquecimento, foram plotados $25 \mu \mathrm{g}$ de proteína em cada poço e iniciou-se a eletroforese com voltagem de $80 \mathrm{~V}$. Os géis de corrida foram preparados na concentração de $15 \%$ de poliacrilamida, enquanto os de empacotamento possuíam $6 \%$ de poliacrilamida. Após a separação proteica por eletroforese, foi realizada a transferência das proteínas para membrana de nitrocelulose $(0,22 \mu \mathrm{m}$, Bio-Rad Laboratories, Inc) utilizando-se o aparelho Trans-Blot ${ }^{\circledR}$ SD Semi-Dry Transfer Cell (Bio-Rad Laboratories, Inc). Após a transferência as membranas foram coradas com o corante Ponceau (controle de loading e normalização), digitalizadas e em seguida lavadas com TBS-T (50 mM Tris; 150 mM NaCl; 0,1\% Tween 20; pH 7,6) até completa remoção do Ponceau. Em seguida, as membranas foram bloqueadas com solução de TBS-T contendo 5\% de leite desnatado por 2 horas com agitação em temperatura ambiente. Após o período de duas horas, a solução de bloqueio foi dispensada e o anticorpo primário (POMC/ACTH antibody, National Hormone and Peptide Program, USA; 1:5000) foi adicionado e as membranas permaneceram sob agitação em geladeira por uma noite. Após este passo, as membranas foram submetidas a 3 lavagens de 15 min, com agitação, em TBS-T e, então, incubadas com anticorpo secundário anti-rabbit (Jackson antibodies) diluído 1:5000 em TBS-T contendo 5\% de leite desnatado, por 1 hora em temperatura ambiente. Posteriormente a esta incubação foram realizadas mais 3 lavagens de 15 
min com TBS-T e as membranas foram incubadas com ECL (Clarity Western ECL Substrate Bio-Rad laboratories) por $2 \mathrm{~min}$. A quimioluminescência emitida pelas membranas foi captada no aparelho Amersham Imager 600 (GE Healthcare Life Sciences).

\subsection{Dosagem de ACTH e corticosterona}

As concentrações de ACTH e corticosterona foram dosadas nos experimentos in vivo com o kit "RSHMAG-69K - MILLIPLEX MAP Rat Stress Hormone Magnetic Bead Panel" (Millipore, Alemanha), seguindo as especificações do fabricante. Já para as amostras de meio de cultura obtidas nos experimentos de secreção estática e perifusão de células hipofisárias utilizamos o kit “CEK-001-21 ACTH Rat and Mouse - Chemiluminescent EIA KIT” (Phoenix Pharmaceuticals, EUA). O meio de cultura da perifusão foi utilizado sem diluição, enquanto o do ensaio de secreção estática foi diluído $4 \mathrm{x}$.

\subsection{Análise estatística}

A distribuição dos resultados foi avaliada pelo teste de Kolmogorov-Smirnov. Já que todos os resultados apontaram distribuição normal, utilizamos o teste Anova para comparação e em seguida o teste de Newman-Keuls para avaliar a diferença estatística entre os grupos.

As diferenças foram consideradas significativas para valores de $\mathrm{P}$ menores que 0,05, sendo que foram comparados os grupos hipotiroideos $v s$ os grupos hipotiroideos tratados com hormônio tireoidiano $\left(^{*}\right)$ e controle vs tireoidectomizado (\#). Os dados foram expressos como média \pm erro padrão da média. Todas as análises foram realizadas com o auxílio do programa GraphPad Prism 5. 


\section{RESULTADOS}

\subsection{Estudos in vivo - Tratamento crônico com T3}

Nos experimentos crônicos, os animais foram submetidos à tireoidectomia e após 20 dias sem hormônio tireoidiano foi iniciado o tratamento com doses fisiológica $(0,3 \mu \mathrm{g} / 100 \mathrm{~g})$ e supra fisiológica $(1,5 \mu \mathrm{g} / 100 \mathrm{~g})$ de T3 por 5 dias. Após este período os animais foram sacrificados e componentes do eixo hipotálamo-hipófise-adrenal foram coletados para estudo. Os corações também foram coletados e o seu peso seco em relação ao peso dos animais foi utilizado como controle de eficiência dos tratamentos realizados (fig. 4). A tireoidectomia reduziu o peso do coração dos ratos tireoidectomizados em relação ao peso do coração dos ratos controles e o tratamento com T3 por 5 dias nos ratos tireoidectomizados tratados com dose fisiológica de T3 $(0,3 \mu \mathrm{g} / 100 \mathrm{~g})$ reestabeleceu o peso a valores iguais aos dos animais controle. O tratamento com dose supra fisiológica de T3 $(1,5 \mu \mathrm{g} / 100 \mathrm{~g})$ tornou o coração dos animais deste grupo mais pesados que de todos os outros grupos, inclusive o dos animais Tx tratados com dose fisiológica.

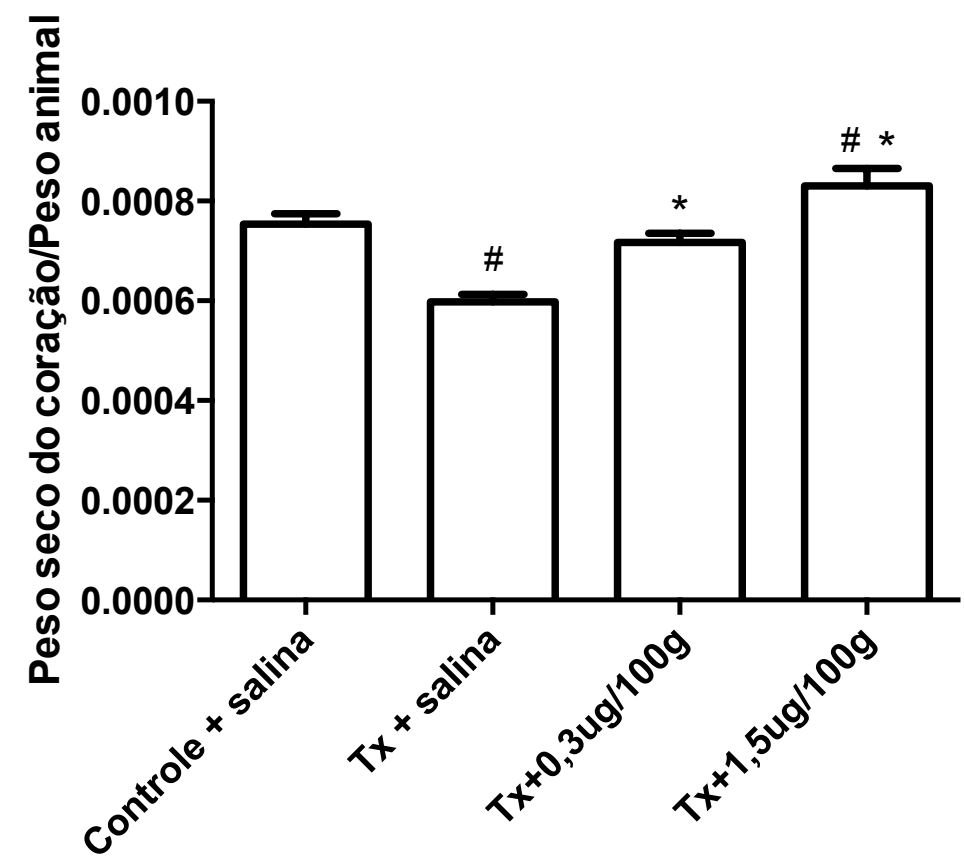

Figura 4 - Peso seco dos corações normalizado pelo peso dos ratos $(n=10)$ controles tratados com salina, tireoidectomizados ( $\mathrm{Tx}$ ) tratados com salina (Tx + salina), Tx tratados com dose fisiológica de T3 ( $\mathrm{Tx}+0,3 \mu \mathrm{g} / 100 \mathrm{~g})$ e Tx tratados com dose supra fisiológica de $\mathrm{T3}(\mathrm{Tx}+1,5 \mu \mathrm{g} / 100 \mathrm{~g})$ por 5 dias. ANOVA unifatorial seguido pelo teste de comparações múltiplas de Newman-Keuls ( $p<0,001$ para Controle + salina vs Tx + salina e Tx + salina vs Tx+1,5 $\mu \mathrm{g} / 100 \mathrm{~g}$, $\mathrm{p}<0,01$ para $\mathrm{Tx}+$ salina vs $\mathrm{Tx}+0,3 \mu \mathrm{g} / 100 \mathrm{~g}$ e Tx+0,3 $\mu \mathrm{g} / 100 \mathrm{~g} v s \mathrm{Tx}+1,5 \mu \mathrm{g} / 100 \mathrm{~g}$ e $\mathrm{p}<0,05$ para Controle + salina vs $\mathrm{Tx}+$ $1,5 \mu \mathrm{g} / 100 \mathrm{~g})$. 


\subsubsection{Hipófise}

$\mathrm{Na}$ hipófise, detectamos uma queda na expressão gênica da POMC no grupo tireoidectomizado em relação ao grupo controle. O tratamento com hormônio tireoidiano na concentração fisiológica não promoveu alteração significativa nesse parâmetro, enquanto que com a dose de 1,5 $\mu \mathrm{g} / 100 \mathrm{~g}$, o T3 provocou elevação da expressão desse gene, embora os valores tenham ficado abaixo dos do grupo controle (Fig. 5). Ainda na hipófise, foi observado que a expressão do mRNA da enzima pró-hormônio convertase do tipo 1 (mRNA PC1) apresentou-se aumentada no grupo tireoidectomizado e que o tratamento com hormônio tireoidiano, em ambas as doses, foi capaz de reduzir sua expressão a níveis similares aos do controle (Fig. 6).

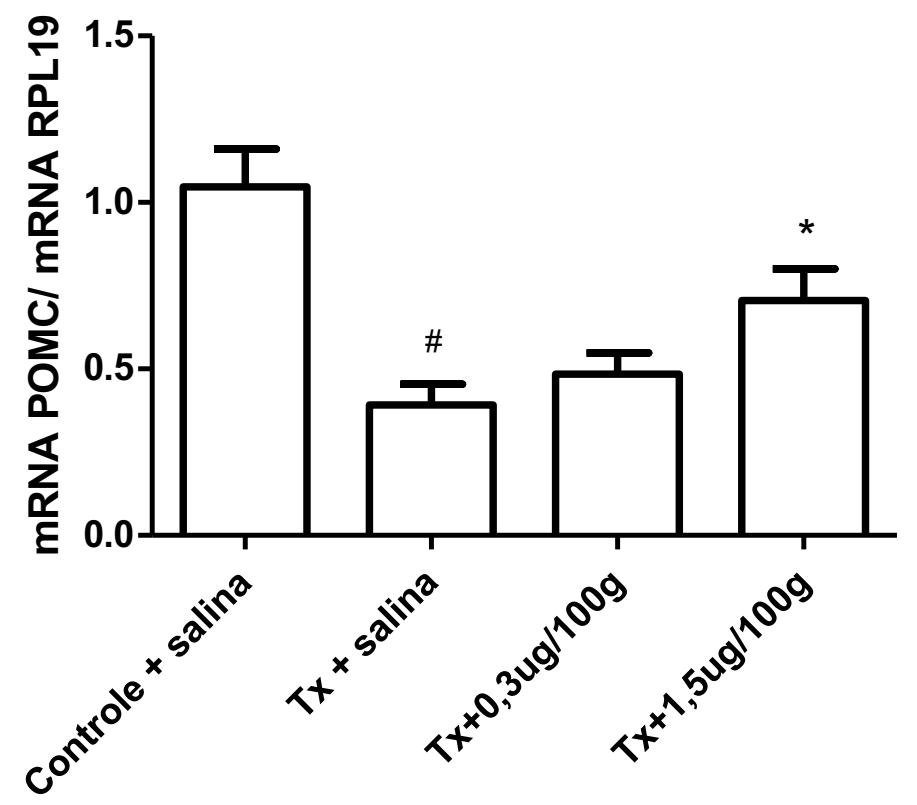

Figura 5 - Avaliação da expressão gênica da POMC por qPCR em ratos $(n=10)$ controles tratados com salina, tireoidectomizados (Tx) tratados com salina (Tx + salina), Tx tratados com dose fisiológica de T3 (Tx + 0,3 $\mu \mathrm{g} / 100 \mathrm{~g}$ ) e Tx tratados com dose supra fisiológica de $T 3(T x+1,5 \mu \mathrm{g} / 100 \mathrm{~g})$ por 5 dias. ANOVA unifatorial seguido pelo teste de comparações múltiplas de Newman-Keuls ( $p<0,001$ para Controle+salina vs. Tx+salina e $p<0,05$ para Tx + salina vs. Tx+1,5 ug/ $100 \mathrm{~g})$. 


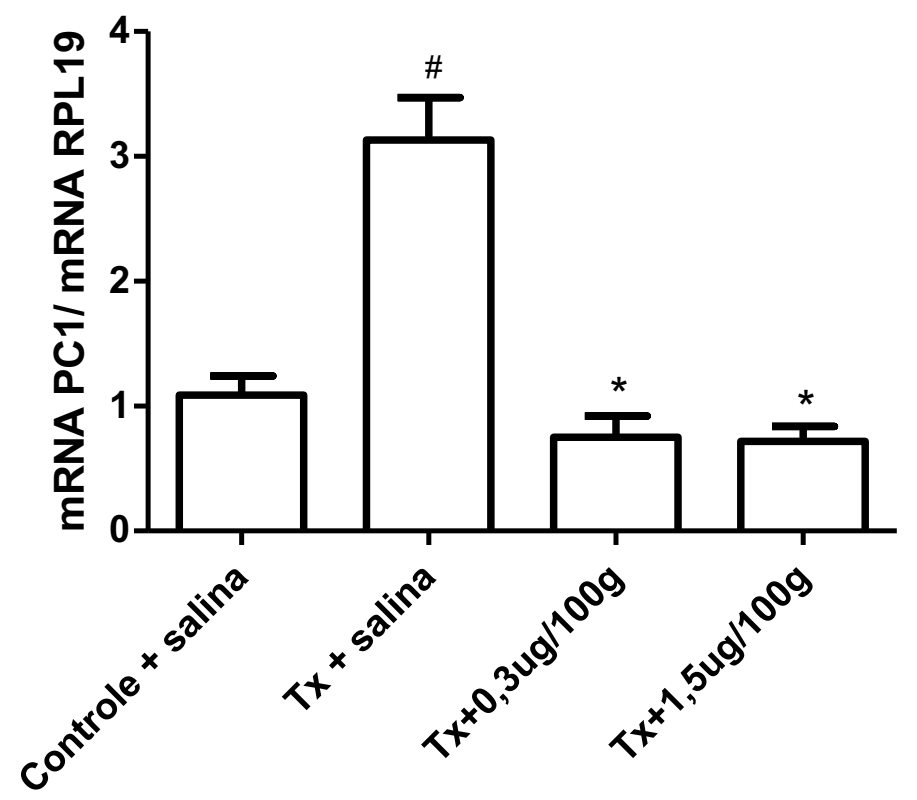

Figura 6 - Avaliação da expressão gênica da PC1 por qPCR em ratos $(n=10)$ controles tratados com salina, tireoidectomizados (Tx) tratados com salina (Tx + salina), Tx tratados com dose fisiológica de T3 (Tx + 0,3 $\mu \mathrm{g} / 100 \mathrm{~g}$ ) e Tx tratados com dose supra fisiológica de T3 $(\mathrm{Tx}+1,5 \mu \mathrm{g} / 100 \mathrm{~g})$ por 5 dias. ANOVA unifatorial seguido pelo teste de comparações múltiplas de Newman-Keuls ( $p<0,001$ para controle+salina vs. Tx+salina e $p<0,001$ para Tx + salina vs. Tx + $0,3 \mu \mathrm{g} / 100 \mathrm{~g}$ e $\mathrm{Tx}+1,5 \mu \mathrm{g} / 100 \mathrm{~g})$.

Em relação ao conteúdo de POMC e ACTH (fig. 7), não foram encontradas diferenças significativas entre os grupos, embora um indício de aumento de POMC pareça ocorrer no grupo tireoidectomizado tratado com dose supra-fisiológica de T3. 


\section{POMC}

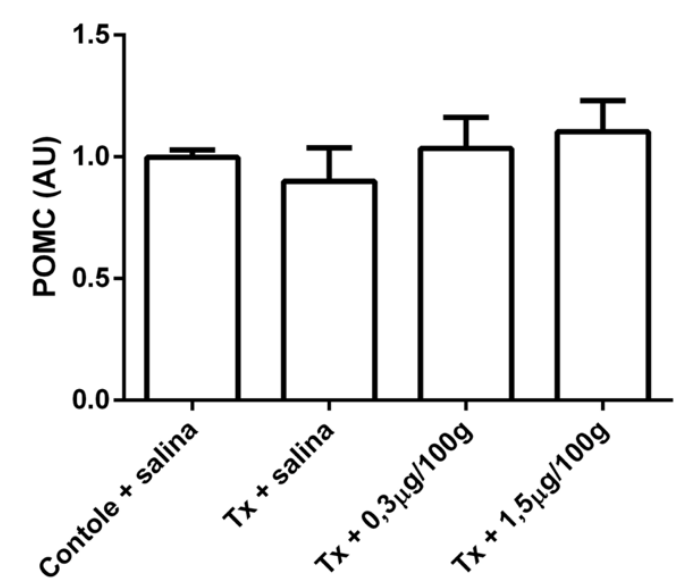

\section{ACTH}

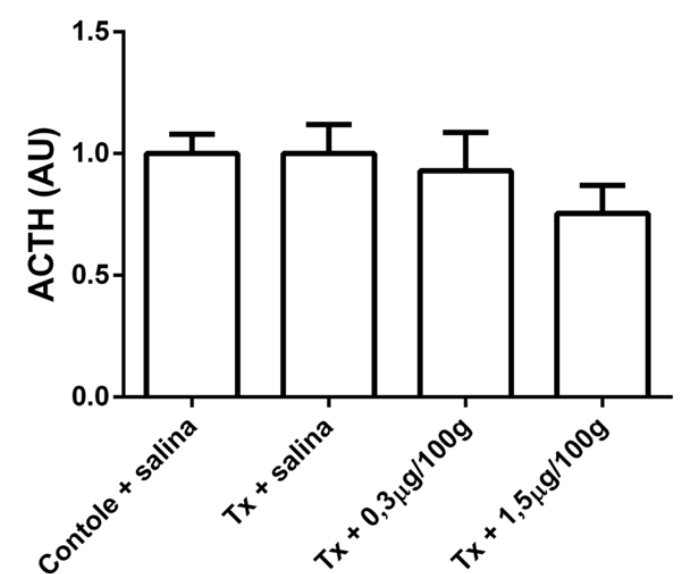

Figura 7 - Avaliação do conteúdo intracelular de POMC e ACTH por Western blotting em ratos $(n=7)$ controles tratados com salina, tireoidectomizados ( $\mathrm{Tx}$ ) tratados com salina ( $\mathrm{Tx}+$ salina), Tx tratados com dose fisiológica de T3 ( $\mathrm{Tx}+0,3 \mu \mathrm{g} / 100 \mathrm{~g}$ ) e Tx tratados com dose supra fisiológica de T3 $(\mathrm{Tx}+1,5 \mu \mathrm{g} / 100 \mathrm{~g})$ por 5 dias. ANOVA unifatorial seguido pelo teste de comparações múltiplas de Newman-Keuls.

\subsubsection{Hipotálamo}

No hipotálamo, o conteúdo de mRNA do CRH do grupo Tx permaneceu semelhante ao do grupo controle (eutiroideo). Contudo, foi detectado um aumento da expressão deste transcrito (fig. 8) quando os animais dos grupos Tx foram tratados com T3 tanto na dose fisiológica $(\mathrm{Tx}+0,3 \mu \mathrm{g} / 100 \mathrm{~g})$ como na suprafisiológica $(\mathrm{Tx}+1,5 \mu \mathrm{g} / 100 \mathrm{~g})$, em relação aos grupos controle e Tx. 


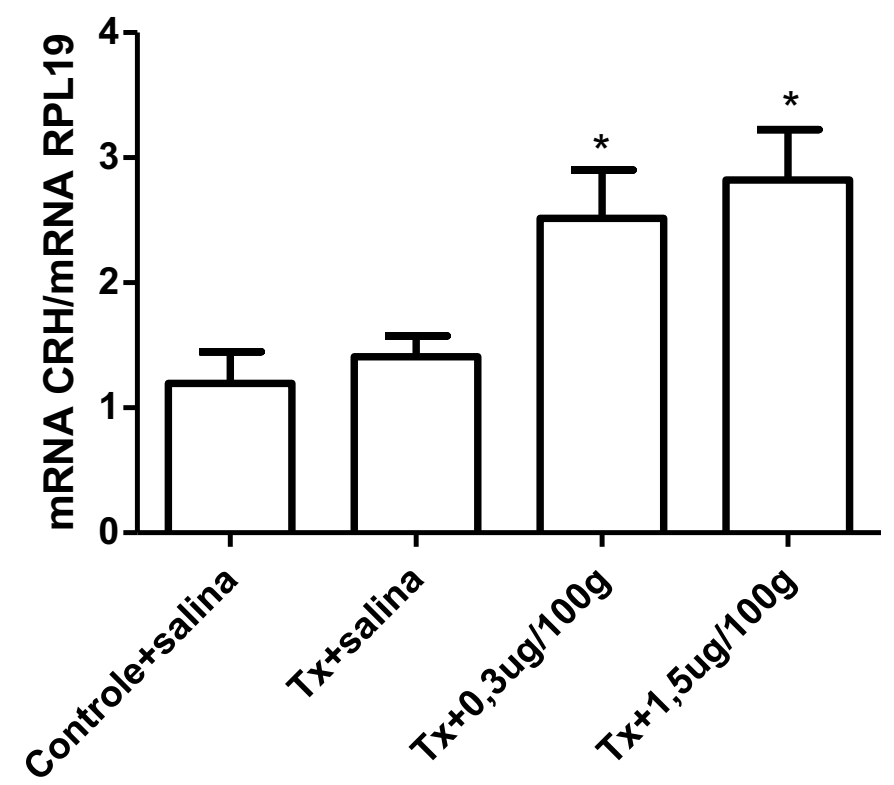

Figura 8 - Avaliação da expressão gênica do CRH por qPCR em ratos $(n=10)$ controles tratados com salina, tireoidectomizados (Tx) tratados com salina ( $\mathrm{Tx}+$ salina), Tx tratados com dose fisiológica de T3 (Tx + 0,3 $\mu \mathrm{g} / 100 \mathrm{~g})$ e Tx tratados com dose supra fisiológica de $\mathrm{T3}(\mathrm{Tx}+1,5 \mu \mathrm{g} / 100 \mathrm{~g})$ por 5 dias. ANOVA unifatorial seguido pelo teste de

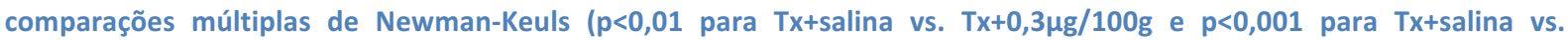
$\mathrm{Tx}+1,5 \mu \mathrm{g} / 100 \mathrm{~g})$.

\subsubsection{Adrenais}

Conforme mostrado na figura 9, a tireoidectomia provocou redução no peso das adrenais (Controle + salina $v s \mathrm{Tx}+$ salina). Adicionalmente, um aumento no peso das glândulas foi detectado quando comparamos as adrenais dos animais $\mathrm{Tx}$ que receberam a dose supra fisiológica de hormônio tireoidiano por 5 dias com as adrenais dos animais tireoidectomizados tratados com salina.

Quanto à expressão gênica das enzimas responsáveis pela síntese de glicocorticóides (StAR, CYP11A1, CYP11B1 e CYP11B2), também não foram detectadas alterações significativas nesses parâmetros (Fig 10 a 13) entre os grupos estudados. 


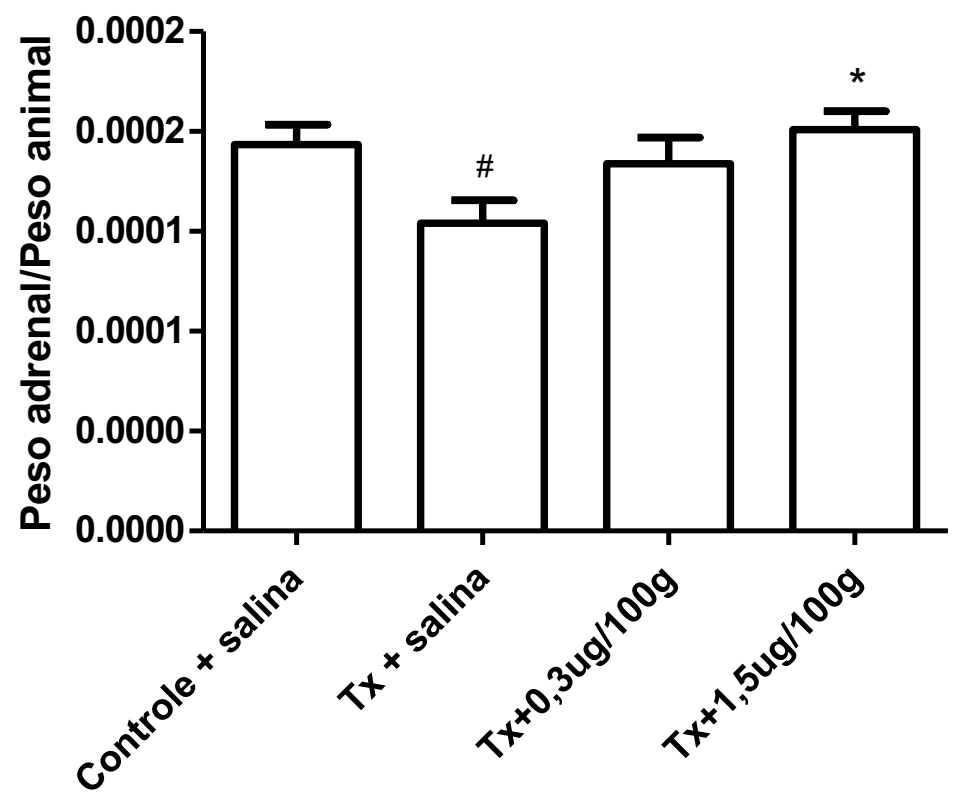

Figura 9 - Relação entre o peso das adrenais direita e esquerda em relação ao peso total de ratos $(n=9)$ controles tratados com salina, tireoidectomizados ( $\mathrm{Tx}$ ) tratados com salina ( $\mathrm{Tx}+$ salina), Tx tratados com dose fisiológica de T3 (Tx + 0,3 $\mu \mathrm{g} /$ $100 \mathrm{~g})$ e Tx tratados com dose supra fisiológica de $\mathrm{T} 3(\mathrm{Tx}+1,5 \mu \mathrm{g} / 100 \mathrm{~g})$ por 5 dias. ANOVA unifatorial seguido pelo teste de comparações múltiplas de Newman-Keuls ( $p<0,05$ para Controle+salina vs Tx+salina e $p<0,05$ para Tx+salina vs $\mathrm{Tx}+1,5$ $\mu \mathrm{g} / 100 \mathrm{~g})$.

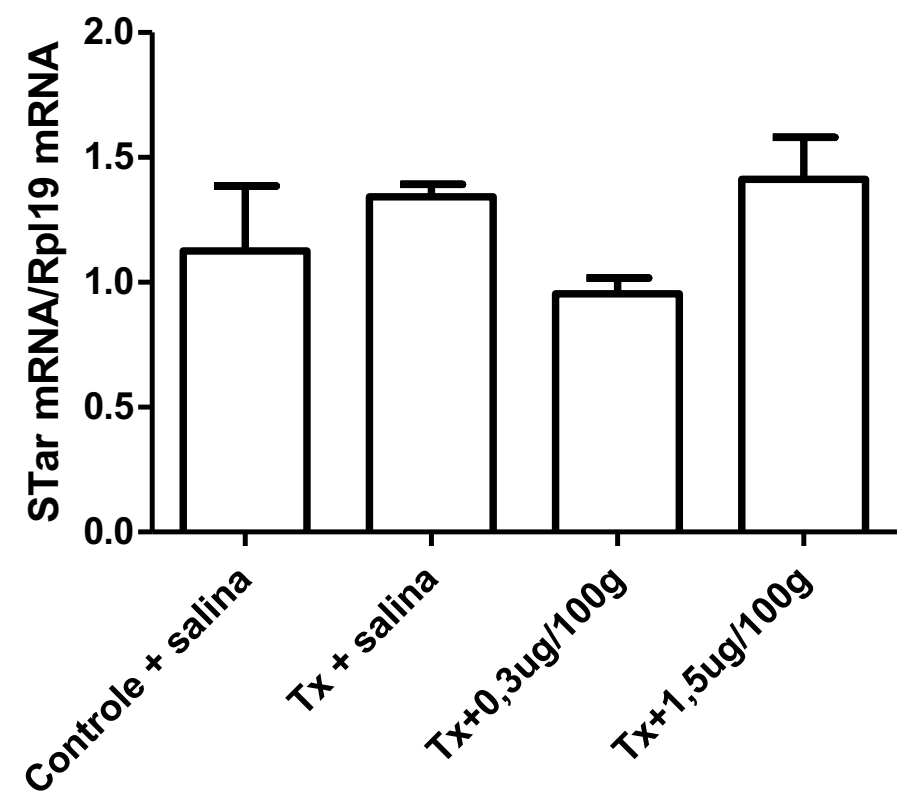

Figura 10 - Avaliação da expressão gênica da enzima StAR por qPCR em ratos $(n=5)$ controles tratados com salina, tireoidectomizados ( $\mathrm{Tx}$ ) tratados com salina (Tx + salina), Tx tratados com dose fisiológica de T3 ( $\mathrm{Tx}+0,3 \mu \mathrm{g} / 100 \mathrm{~g})$ e Tx tratados com dose supra fisiológica de $\mathrm{T3}(\mathrm{Tx}+1,5 \mu \mathrm{g} / 100 \mathrm{~g})$ por 5 dias. ANOVA unifatorial seguido pelo teste de comparações múltiplas de Newman-Keuls. 


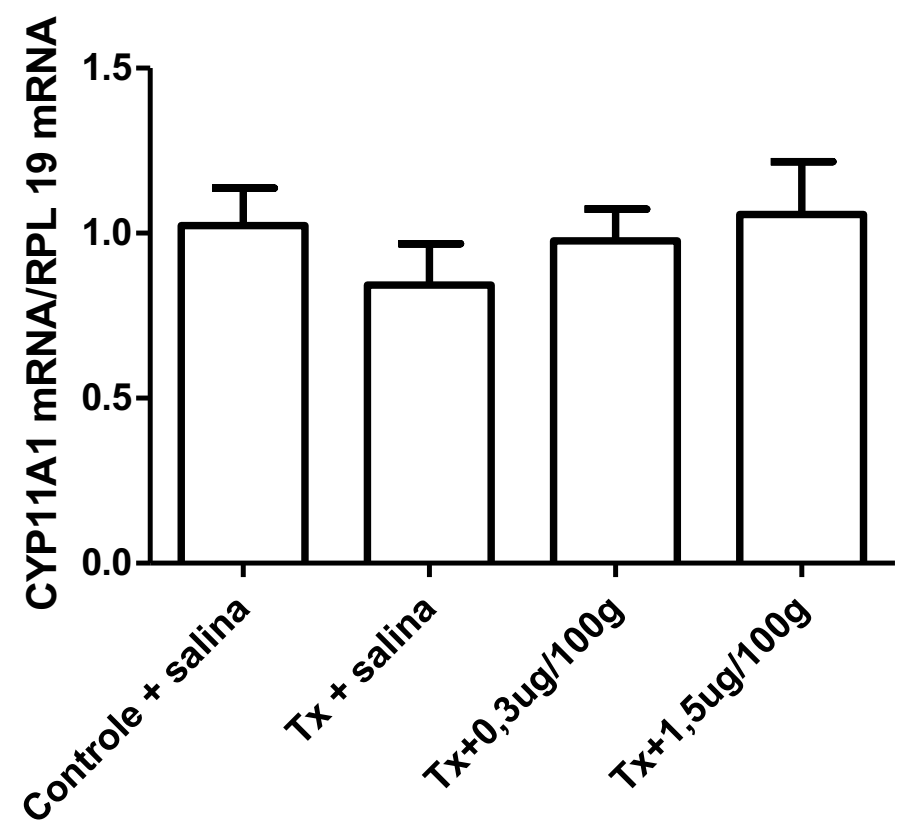

Figura 11 - Avaliação da expressão gênica da enzima CYP11A1 por qPCR em ratos $(n=5)$ controles tratados com salina, tireoidectomizados ( $\mathrm{Tx}$ ) tratados com salina ( $\mathrm{Tx}+$ salina), Tx tratados com dose fisiológica de $\mathrm{T} 3(\mathrm{Tx}+0,3 \mu \mathrm{g} / 100 \mathrm{~g})$ e $\mathrm{Tx}$ tratados com dose supra fisiológica de $T 3(T x+1,5 \mu \mathrm{g} / 100 \mathrm{~g})$ por 5 dias. ANOVA unifatorial seguido pelo teste de comparações múltiplas de Newman-Keuls.

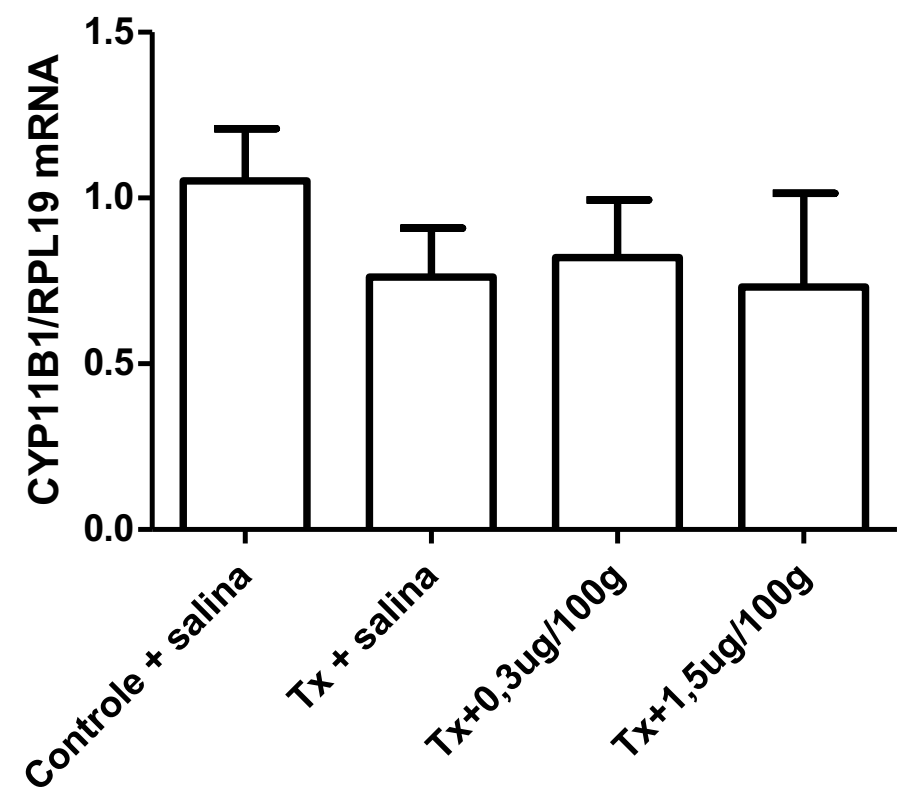

Figura 12 - Avaliação da expressão gênica da enzima CYP11B1 por qPCR em ratos $(n=5)$ controles tratados com salina, tireoidectomizados ( $\mathrm{Tx}$ ) tratados com salina (Tx + salina), Tx tratados com dose fisiológica de T3 ( $\mathrm{Tx}+0,3 \mu \mathrm{g} / 100 \mathrm{~g})$ e Tx tratados com dose supra fisiológica de $\mathrm{T3}(\mathrm{Tx}+1,5 \mu \mathrm{g} / 100 \mathrm{~g})$ por 5 dias. ANOVA unifatorial seguido pelo teste de comparações múltiplas de Newman-Keuls. 


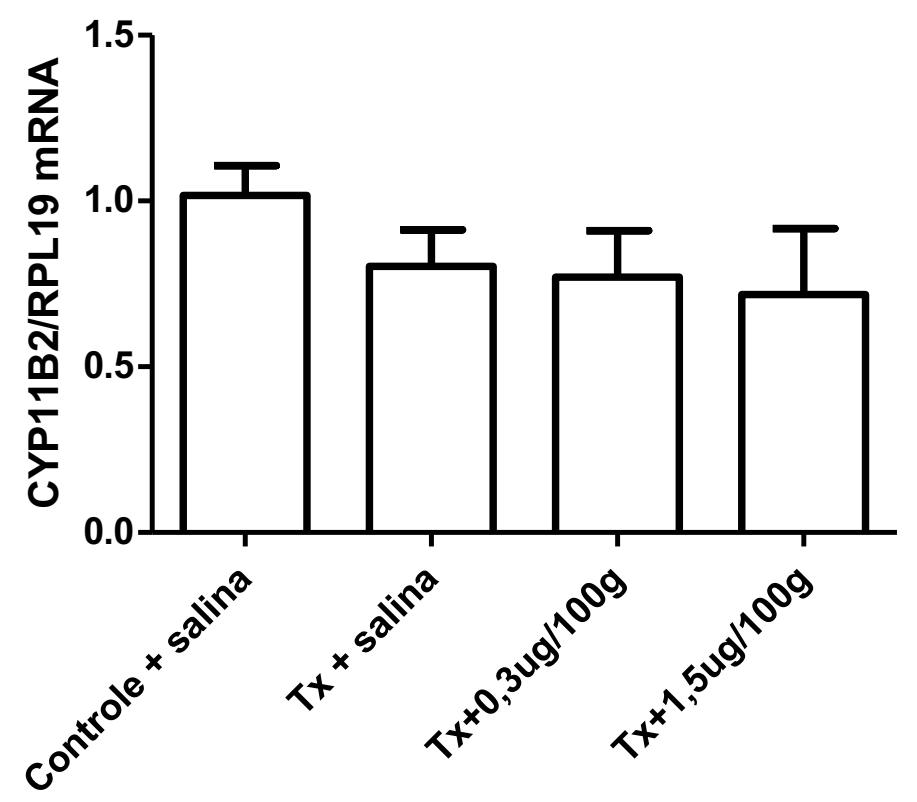

Figura 13 - Avaliação da expressão gênica da enzima CYP11B2 por qPCR em ratos $(n=10)$ controles tratados com salina, tireoidectomizados ( $\mathrm{Tx}$ ) tratados com salina ( $\mathrm{Tx}+$ salina), Tx tratados com dose fisiológica de T3 ( $\mathrm{Tx}+0,3 \mu \mathrm{g} / 100 \mathrm{~g}$ ) e Tx tratados com dose supra fisiológica de $\mathrm{T} 3(\mathrm{Tx}+1,5 \mu \mathrm{g} / 100 \mathrm{~g})$ por 5 dias. ANOVA unifatorial seguido pelo teste de comparações múltiplas de Newman-Keuls.

\subsubsection{Dosagem sérica de ACTH e corticosterona}

Os valores séricos de ACTH estão apresentados na figura 14. Os animais Tx apresentaram valores de $\mathrm{ACTH}$ reduzidos em comparação aos animais controle $(\mathrm{P}<0,05)$. $\mathrm{O}$ tratamento com T3 na dose fisiológica não alterou o ACTH circulante nesses animais em relação ao grupo Tx, mas seus valores se igualaram aos valores séricos dos animais controle. Já a dose supra fisiológica $(1,5 \mu \mathrm{g} / 100 \mathrm{~g})$ elevou a concentração de ACTH em relação aos grupos Tx $(\mathrm{P}<0,01)$ e $\mathrm{Tx}+0,3 \mu \mathrm{g} / 100 \mathrm{~g}(\mathrm{P}<0,05)$ e equiparou-se aos valores séricos do grupo controle.

As concentrações séricas de corticosterona (fig. 15) não apresentaram alterações em nenhum dos tratamentos efetuados. 


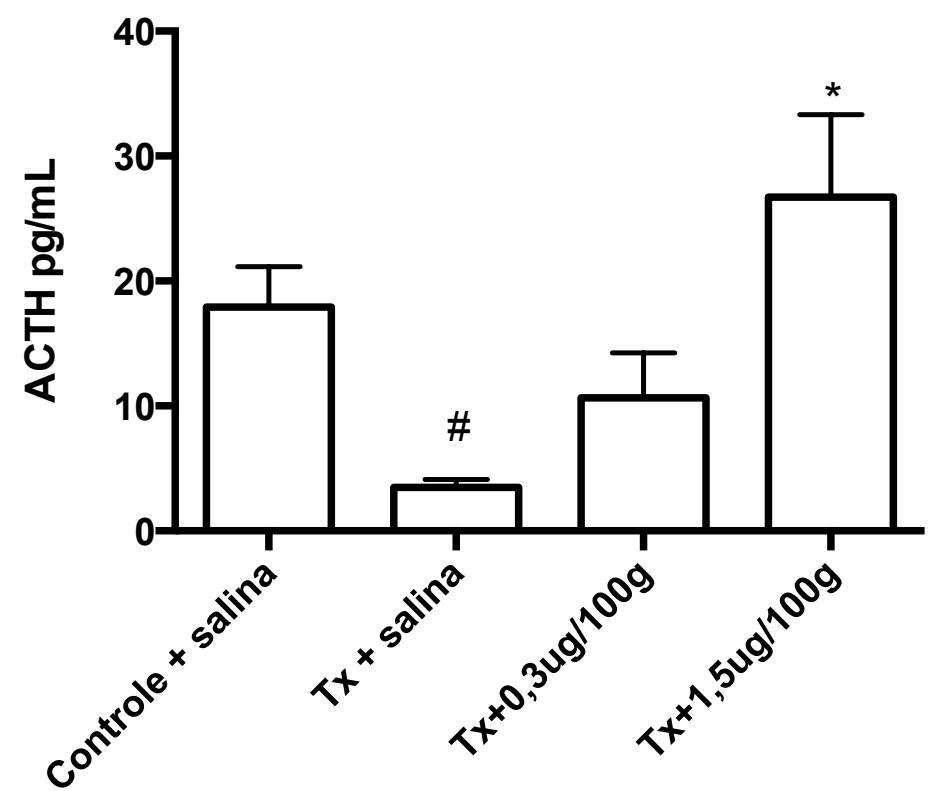

Figura 14 - Valores séricos de ACTH em ratos ( $n=12$ ) controles tratados com salina, tireoidectomizados (Tx) tratados com salina (Tx + salina), Tx tratados com dose fisiológica de T3 $(\mathrm{Tx}+0,3 \mu \mathrm{g} / 100 \mathrm{~g})$ e Tx tratados com dose supra fisiológica de T3 $(\mathrm{Tx}+1,5 \mu \mathrm{g} / 100 \mathrm{~g})$ por 5 dias. ANOVA unifatorial seguido pelo teste de comparações múltiplas de Newman-Keuls ( $p<0,05$ para Controle + salina vs Tx + salina e Tx + 0,3 $\mu \mathrm{g} / 100 \mathrm{~g}$ vs $\mathrm{Tx}+1,5 \mu \mathrm{g} / 100 \mathrm{~g}, \mathrm{p}<0,01$ para Tx + salina vs Tx + 1,5 $\mu \mathrm{g} / 100 \mathrm{~g})$.

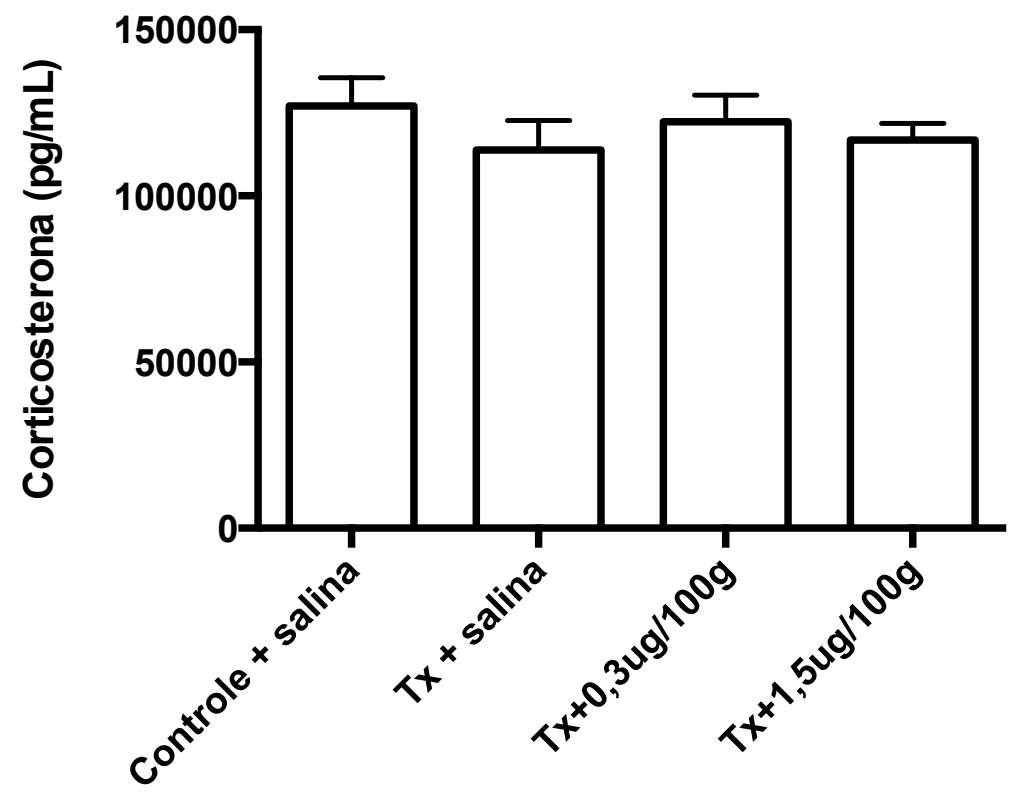

Figura 15 - Valores séricos de corticosterona em ratos $(n=12)$ controles tratados com salina, tireoidectomizados (Tx) tratados com salina ( $\mathrm{Tx}+$ salina), Tx tratados com dose fisiológica de $\mathrm{T} 3(\mathrm{Tx}+0,3 \mu \mathrm{g} / 100 \mathrm{~g}$ ) e Tx tratados com dose supra fisiológica de T3 (Tx + 1,5 $\mu \mathrm{g} / 100 \mathrm{~g})$ por 5 dias. ANOVA unifatorial seguido pelo teste de comparações múltiplas de Newman-Keuls. 


\subsection{Estudos in vivo - Tratamento agudo com T3}

Nos experimentos com tratamento agudo de $\mathrm{T} 3$, os animais foram submetidos a tireoidectomia e após 20 dias sem HTs na circulação receberam uma única injeção intravenosa de T3 em dose fisiológica $(0,3 \mu \mathrm{g} / 100 \mathrm{~g})$ ou dose suprafisiológica $(100 \mu \mathrm{g} / 100 \mathrm{~g}) 30 \mathrm{~min}$ antes de serem sacrificados.

A figura 16 ilustra o efeito do tratamento agudo $(30 \mathrm{~min})$ com T3 sobre a expressão gênica da POMC em ratos Tx. Ela reitera os dados da figura 4 que mostram que na ausência de HTs ocorre uma redução significativa $(\mathrm{P}<0,0001)$ da expressão gênica da POMC.

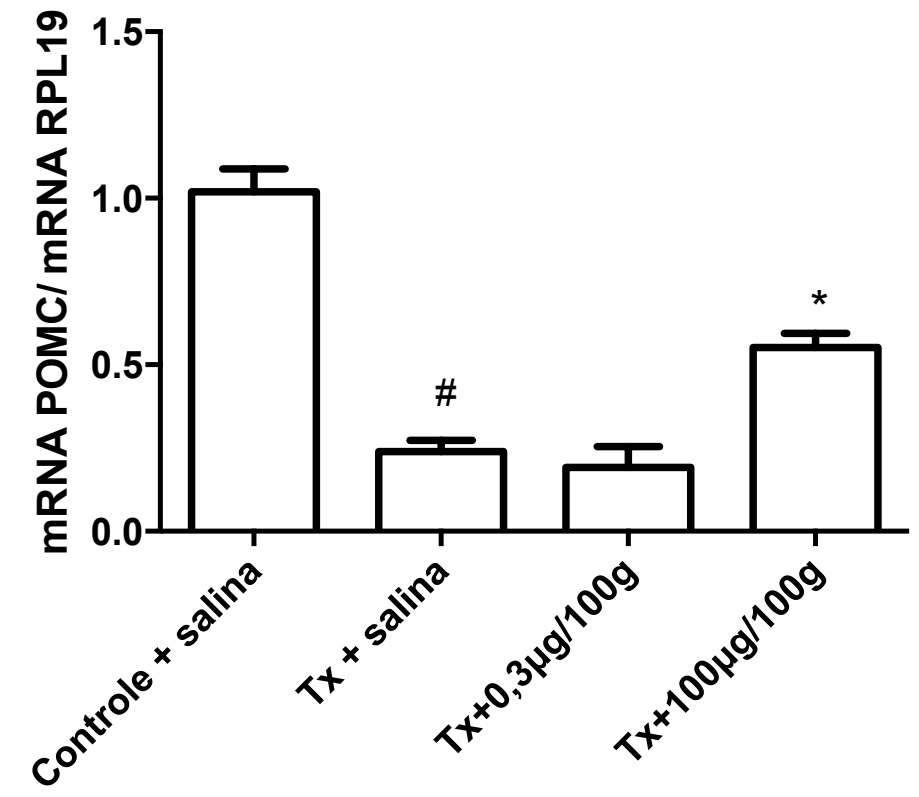

Figura 16 - Avaliação da expressão gênica da proopiomelanocortina por qPCR em animais ( $n=8)$ controles tratados com salina, tireoidectomizados (Tx) tratados com salina (Tx + salina), Tx tratados com dose fisiológica de T3 (Tx + $03 \mu \mathrm{g} / 100 \mathrm{~g}$ ) e tireoidectomizados tratados com T3 na dose de $100 \mu \mathrm{g} / 100 \mathrm{~g}$ (Tx $+100 \mu \mathrm{g} / 100 \mathrm{~g}$ ) por 30 min. ANOVA unifatorial seguido pelo teste de comparações múltiplas de Newman-Keuls $(p<0,0001$ para Controle + salina vs Tx + salina e $p<0,001$ para Tx + salina vs $\mathrm{Tx}+100 \mu \mathrm{g} / 100 \mathrm{~g})$.

Verificamos também que a triiodotironina, quando injetada na dose suprafisiológica em ratos tireoidectomizados, é capaz de exercer sua ação rapidamente aumentando o conteúdo de mRNA da POMC (grupo Tx $+100 \mu \mathrm{g} / 100 \mathrm{~g} v s \mathrm{Tx}+$ salina), efeito que não é observado quando 
a dose de T3 injetada é a fisiológica. Esses dados do efeito agudo do T3 se assemelham aos observados nos animais Tx cronicamente tratados com T3.

Em relação à cauda poli(A) do mRNA da POMC (fig. 17), verificamos que o seu comprimento, que guarda relação direta com sua estabilidade e tradução do transcrito, encontrase aumentado no grupo tireoidectomizado em relação ao grupo controle, e que o tratamento desses animais Tx com T3 (dose fisiológica e suprafisiológica) leva a um rápido encurtamento da mesma.

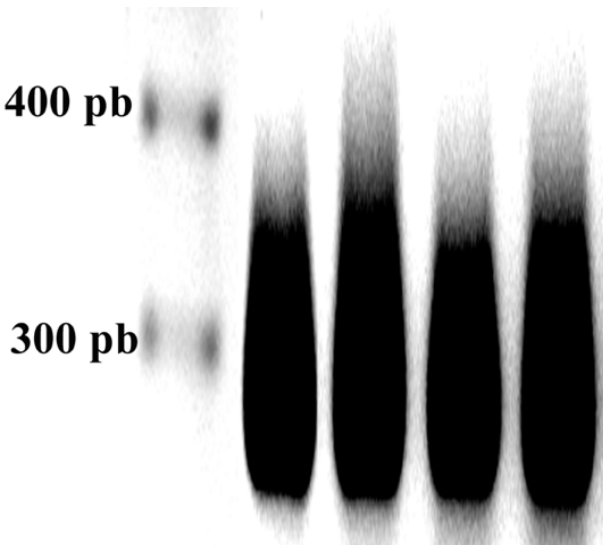

\section{$200 \mathrm{pb}$}
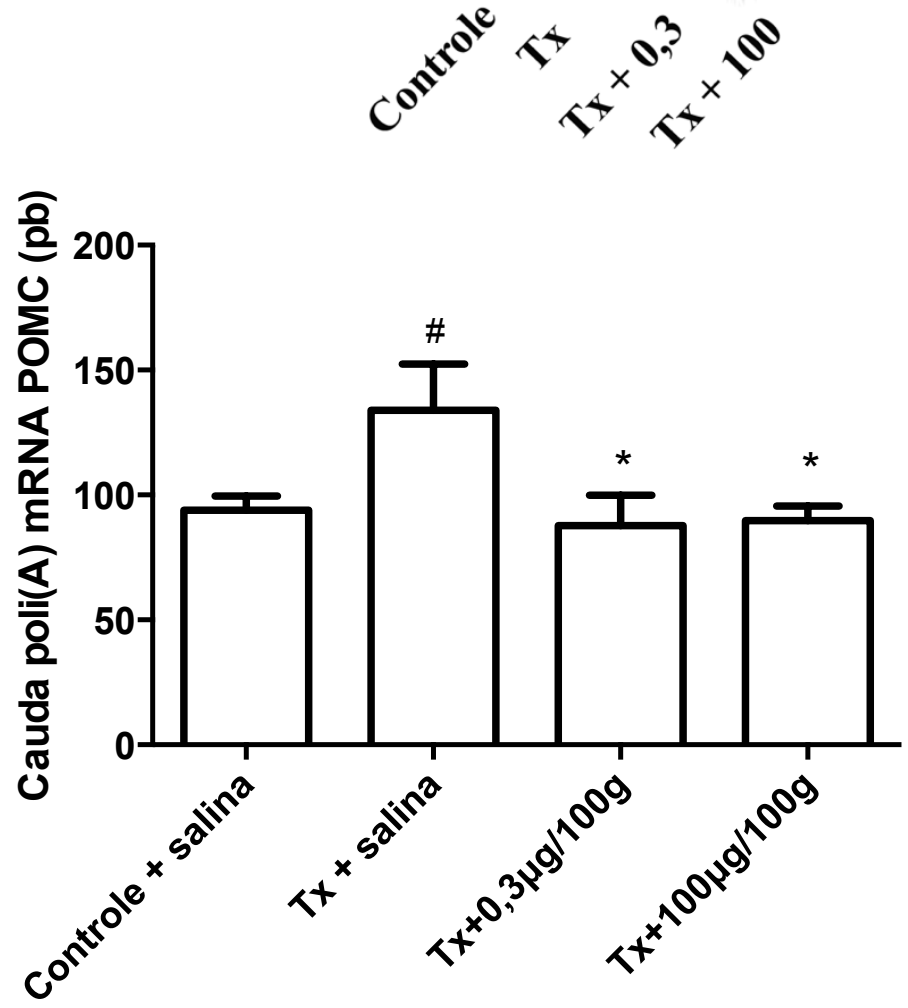

Figura 17 - Avaliação da quantidade de bases da cauda poli(A) do mRNA da proopiomelanocortina em animais (n=4) controles tratados com salina, tireoidectomizados (Tx) tratados com salina (Tx + salina), Tx tratados com dose fisiológica de T3 (Tx $+03 \mu \mathrm{g} / 100 \mathrm{~g}$ ) e tireoidectomizados tratados com T3 na dose de $100 \mu \mathrm{g} / 100 \mathrm{~g}$ (Tx $+100 \mu \mathrm{g} / 100 \mathrm{~g}) \mathrm{por} 30 \mathrm{~min}$. 
ANOVA unifatorial seguido pelo teste de comparações múltiplas de Newman-Keuls ( $p<0,05$ para Controle + salina vs Tx + salina; $p<0,05$ para $\mathrm{Tx}+$ salina vs $\mathrm{Tx}+0,3 \mu \mathrm{g} / 100 \mathrm{~g}$ e Tx + salina vs $\mathrm{Tx}+100 \mu \mathrm{g} / 100 \mathrm{~g}$ ).

Quando levamos em conta a taxa de tradução do transcrito da POMC, observamos um aumento da ligação de mRNA da POMC aos ribossomos no animal Tx, e que o tratamento com T3, tanto aguda (30 min) como cronicamente (5 dias), provoca uma redução da taxa de ligação deste transcrito aos ribossomos.

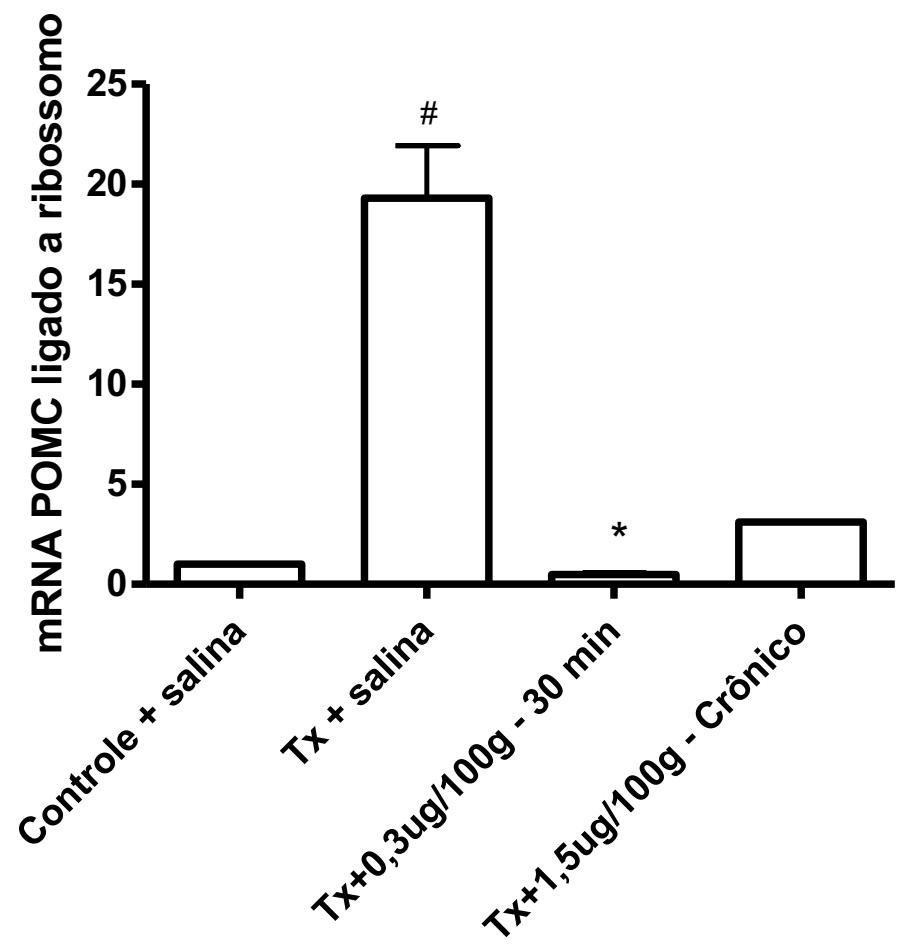

Figura 18 - Avaliação da expressão gênica da POMC por qPCR em ratos ( $n=2$, pool de 10 hipófises) controles tratados com salina, tireoidectomizados tratados com salina, tireoidectomizados tratados com dose fisiológica de hormônio por $\mathbf{3 0}$ min e tireoidectomizados tratados com dose suprafisiológica de hormônio por 5 dias. ANOVA unifatorial seguido pelo teste de comparações múltiplas de Newman-Keuls ( $p<0,01$ para Controle+salina vs Tx+salina e $p<0,01$ para Tx+salina vs $\mathrm{Tx}+0,3 \mu \mathrm{g} /$ $100 \mathrm{~g}-30 \mathrm{~min})$.

Quanto ao conteúdo hipofisário de POMC e ACTH (fig 19) observamos que não foram encontradas diferenças significativas entre os grupos estudados, apesar de existir uma tendência a redução de conteúdo de ACTH em animais Tx tratados com a dose de $100 \mu \mathrm{g} / 100 \mathrm{~g}$. 


\section{POMC}

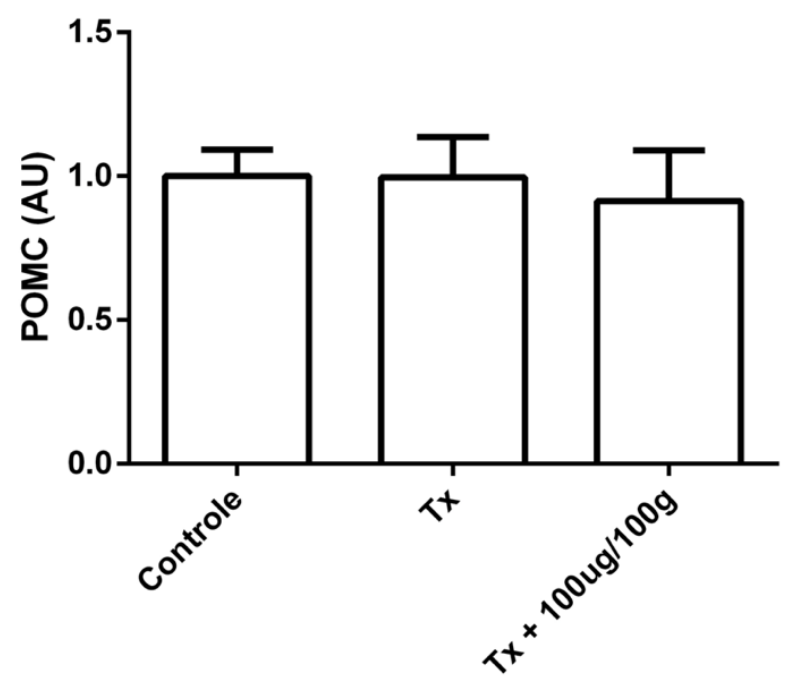

\section{АCTH}

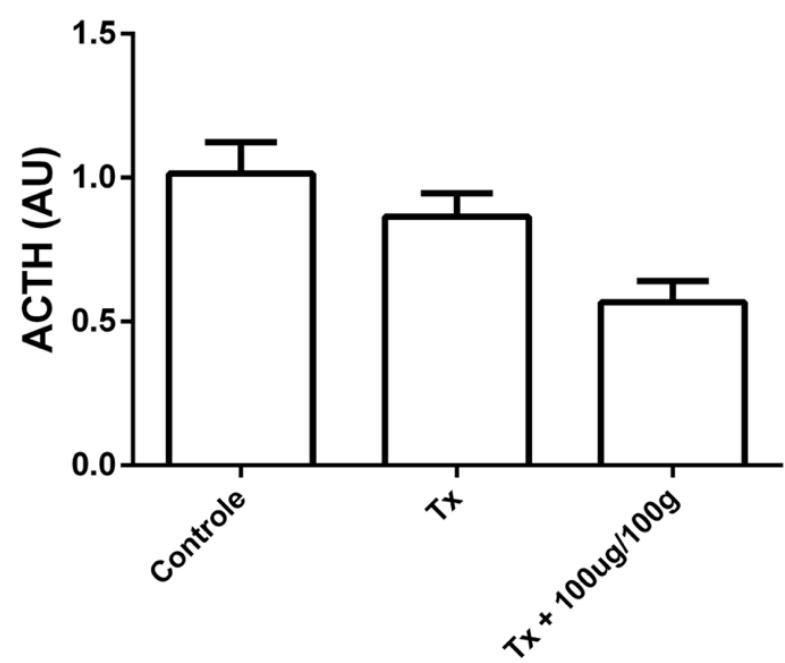

Figura 19 - Avaliação do conteúdo intracelular de POMC e ACTH por Western blotting em ratos $(n=8)$ controles tratados com salina, tireoidectomizados tratados com salina ( $T x$ ) e tireoidectomizados tratados com dose supra fisiológica de T3 (Tx $+100 \mu \mathrm{g} / 100 \mathrm{~g}$ ) por $30 \mathrm{~min}$. ANOVA unifatorial seguido pelo teste de comparações múltiplas de Newman-Keuls.

As figuras 20 e 21 apresentam os valores de ACTH e corticosterona séricos para o estudo agudo. Não houve mudanças na concentração de nenhum dos dois hormônios quando os ratos foram submetidos a tireoidectomia e a injeção intravenosa de T3 ou salina. 


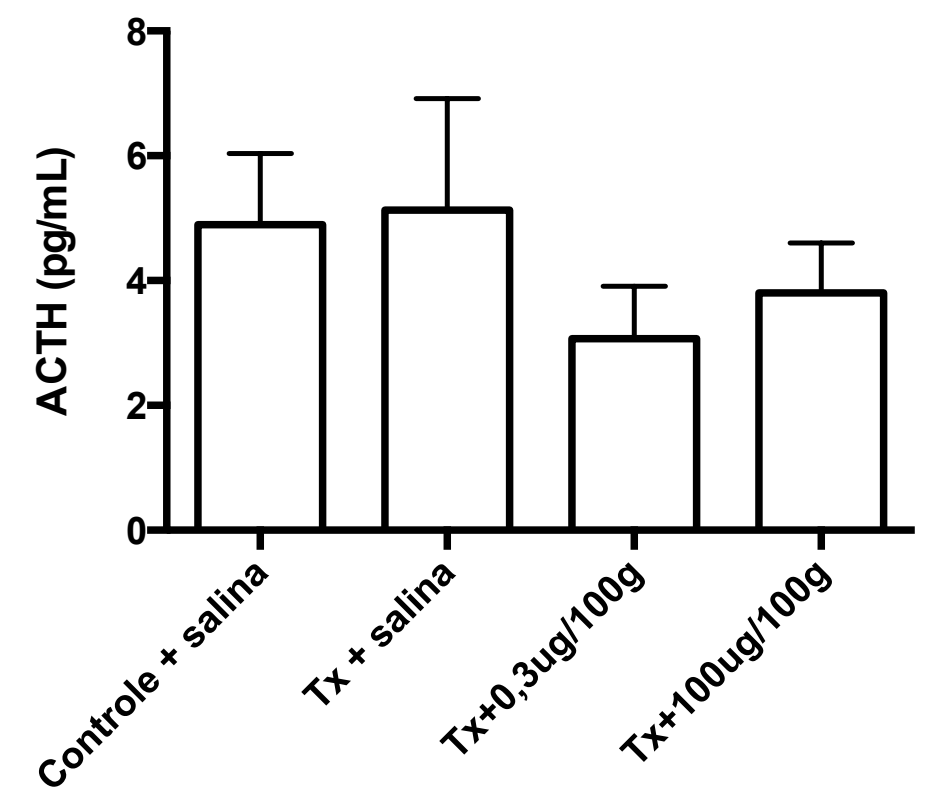

Figura 20 - Valores séricos de ACTH em ratos $(n=8)$ controles tratados com salina, tireoidectomizados $(T x)$ tratados com salina ( $\mathrm{Tx}+$ salina), Tx tratados com dose fisiológica de T3 $(\mathrm{Tx}+0,3 \mu \mathrm{g} / 100 \mathrm{~g})$ e Tx tratados com dose supra fisiológica de $\mathrm{T} 3(\mathrm{Tx}+100 \mu \mathrm{g} / 100 \mathrm{~g})$. ANOVA unifatorial seguido pelo teste de comparações múltiplas de Newman-Keuls.

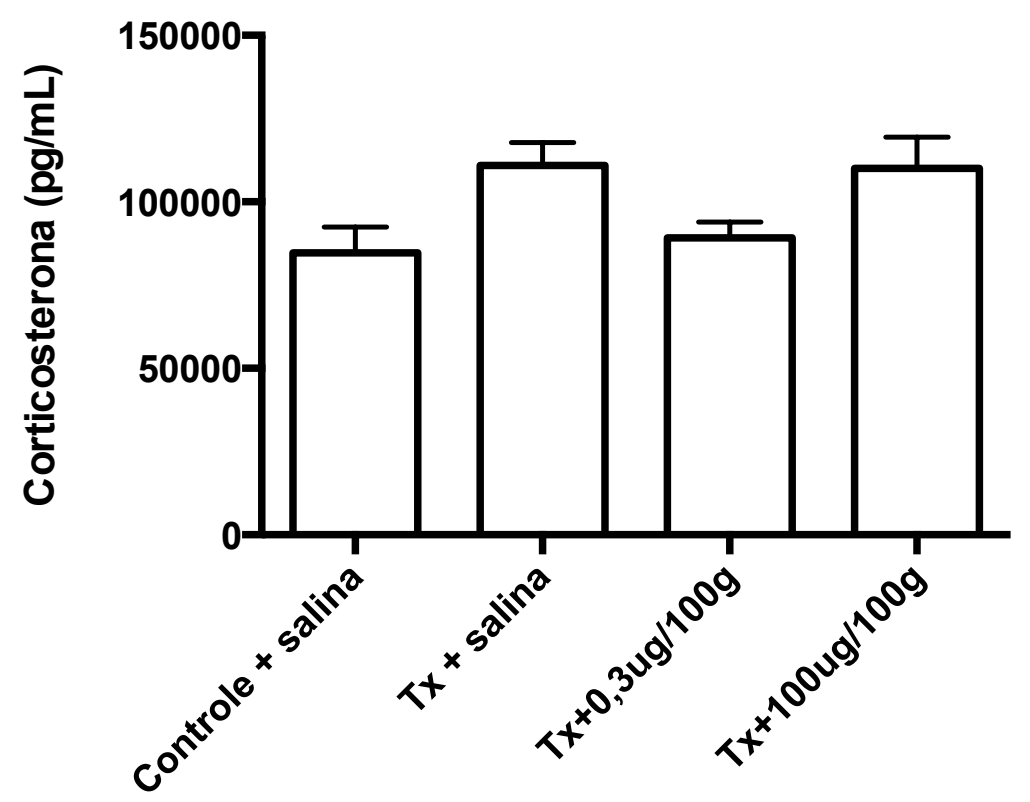

Figura 21 - Valores séricos de corticosterona em ratos $(n=8)$ controles tratados com salina, tireoidectomizados (Tx) tratados com salina ( $T x+$ salina), $T x$ tratados com dose fisiológica de $T 3(T x+0,3 \mu \mathrm{g} / 100 \mathrm{~g})$ e Tx tratados com dose supra fisiológica de T3 (Tx + $100 \mu \mathrm{g} / 100 \mathrm{~g})$. ANOVA unifatorial seguido pelo teste de comparações múltiplas de Newman-Keuls. 


\subsection{Estudos in vitro}

\subsubsection{Cultura primária de hipófises}

Os resultados da figura 22 mostram que não houve diferença na secreção de $\mathrm{ACTH}$ em cultura primária de células hipofisárias tratadas com soro depletado de hormônios tireoidianos (Resina) em relação ao grupo controle. A adição de T3 em diferentes doses $\left(10^{-7}\right.$ e $\left.10^{-9} \mathrm{M}\right)$ por 1 ou 4 horas também não estimulou a secreção de ACTH neste modelo. O tratamento com CRH foi utilizado como controle positivo de secreção e o tratamento de 4 horas não é mostrado na figura, pois seus valores foram superiores ao limite detectável do kit.
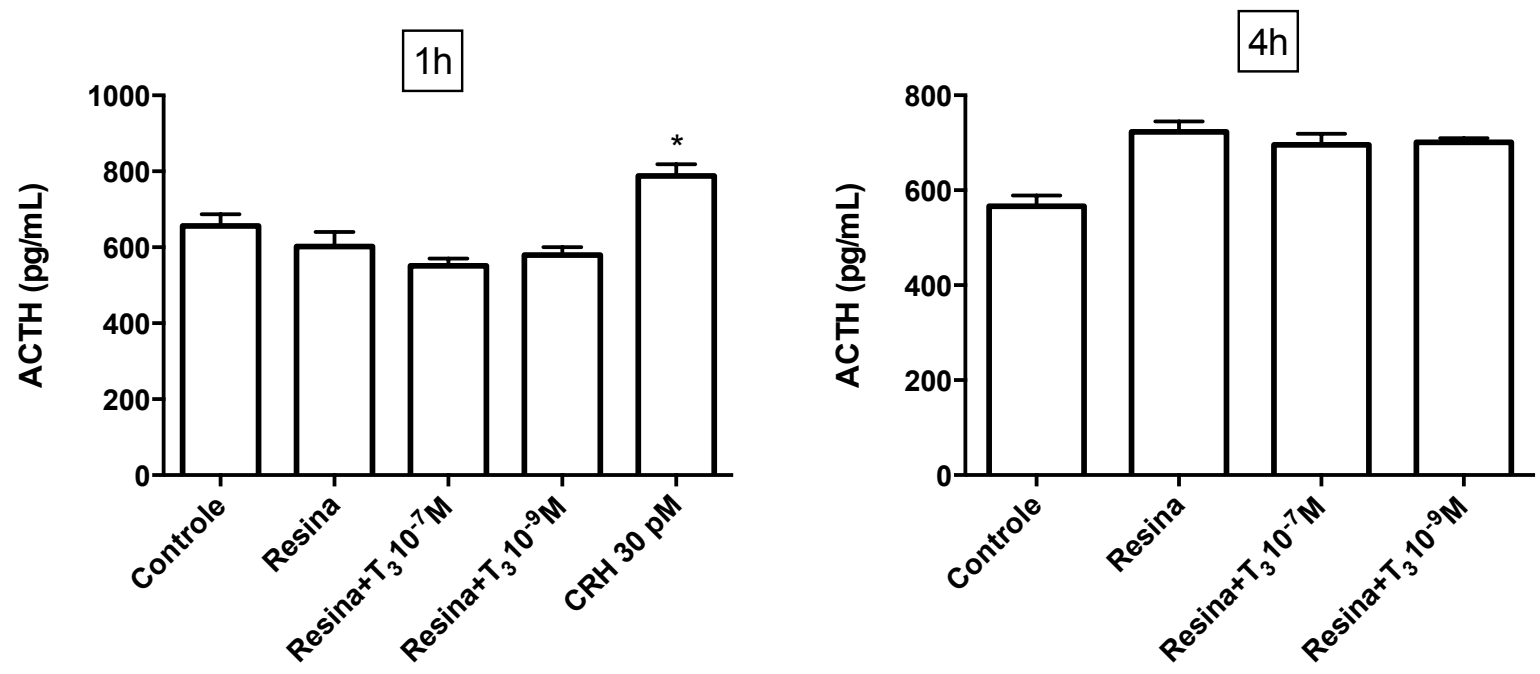

Figura 22 - Avaliação por EIA do efeito de diferentes doses de T3 $\left(10^{-7} \mathrm{M}\right.$ e $\left.10^{-9} \mathrm{M}\right)$ e CRH (30 pM) administrados em diferentes tempos, 1 ou 4 horas, na secreção de ACTH em cultura primária de hipófises ( $n=4)$ mantidas por $24 \mathrm{~h}$ em soro tratado com resina. ANOVA unifatorial seguido pelo teste de comparações múltiplas de Newman-Keuls ( $p<0,01$ para $\mathrm{CRH}$ 30 pM vs Resina, Resina + T3 $10^{-7} \mathrm{M}$, Resina + T3 $10^{-9} \mathrm{M}$ no tratamento de $1 \mathrm{~h}$ ).

Utilizamos o modelo de cultura primária de hipófise para também verificar possíveis efeitos do TRH e TSH na secreção de ACTH e expressão gênica de POMC. O primeiro passo foi verificar a expressão do receptor de TSH na hipófise, o que é mostrado na figura abaixo (fig. 23). 

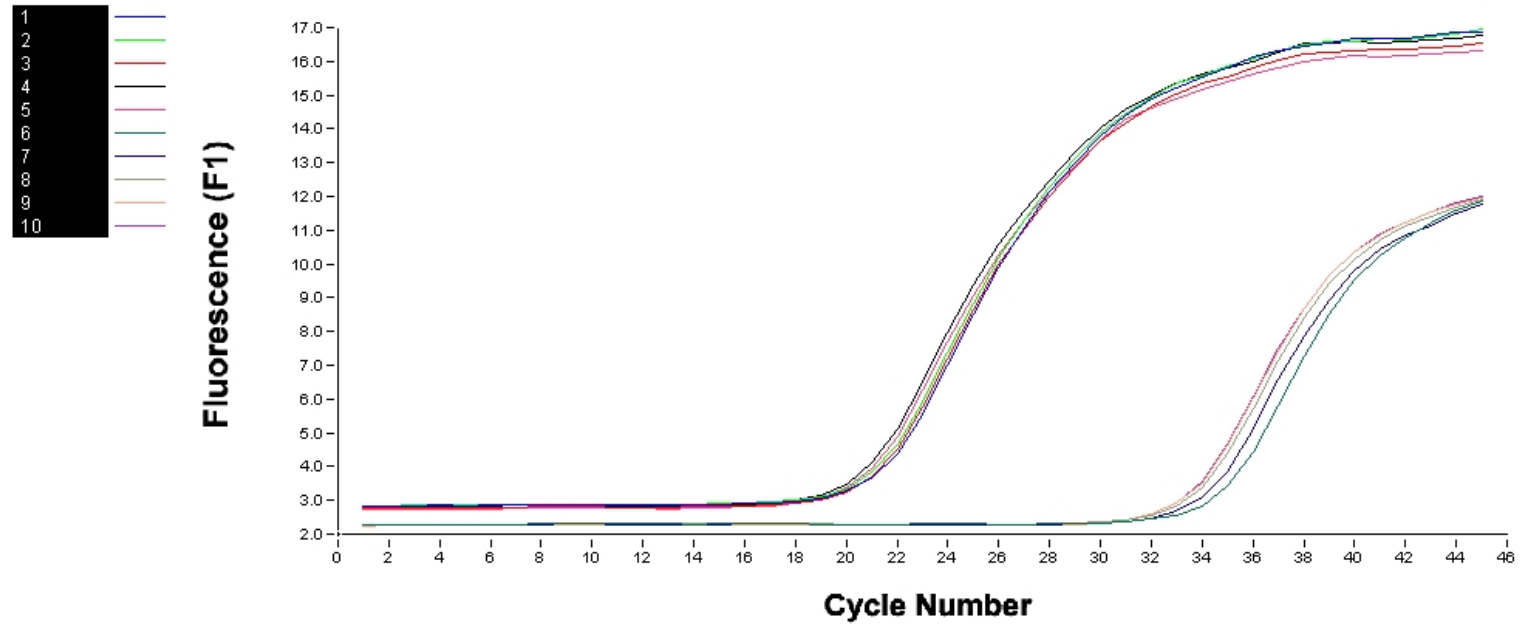

Figura 23 - Avaliação da presença do receptor de TSH por qPCR em cultura primária de hipófises de rato ( $n=5)$. O receptor de TSH teve média do valor de $\mathrm{Ct}=33,49$ e o GAPDH teve um $\mathrm{Ct}$ médio de 20,78.

Após a confirmação da expressão do receptor de TSH na hipófise, verificamos o efeito do TSH na expressão gênica da proopiomelanocortina (fig. 24). Após o tratamento por $6 \mathrm{~h}$ com TSH (1 mU/mL) não ocorreram alterações significativas na expressão de POMC em relação ao grupo controle.

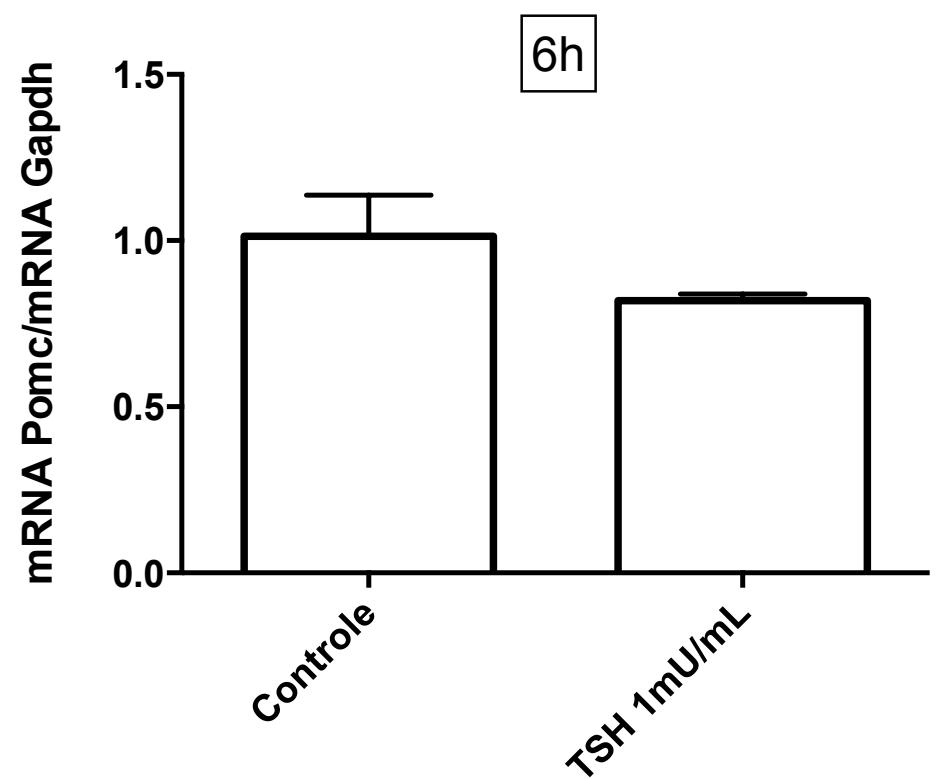

Figura 24 - Avaliação da expressão gênica da POMC por qPCR em cultura primária de células hipofisárias $(n=4)$ tratadas com meio Controle (Meio $199+$ BSA 0,1\%) e TSH (Meio $199+$ BSA 0,1\% + TSH $1 \mathrm{mU} / \mathrm{mL}$ ) por 6 horas. ANOVA unifatorial seguido pelo teste de comparações múltiplas de Newman-Keuls. 
No experimento de secreção estática (fig. 25) verificamos os efeitos do TRH e TSH na secreção de ACTH ao longo de 2, 7 e 19 h de tratamento com esses hormônios. Demonstramos com esse experimento o efeito positivo do TSH na secreção de ACTH, já que a secreção de ACTH encontrou-se aumentada após duas horas de tratamento e se manteve no restante do estudo (7 e 19 h). O hormônio liberador de tireotropina (TRH) não exerceu nenhum efeito na secreção de ACTH, sendo que as células tratadas com TRH apresentaram o mesmo padrão de secreção que o grupo controle. O TRH também não alterou a secreção de ACTH causada por TSH, já que o grupo TRH + TSH apresentou valores de secreção iguais ao grupo tratado apenas com TSH.
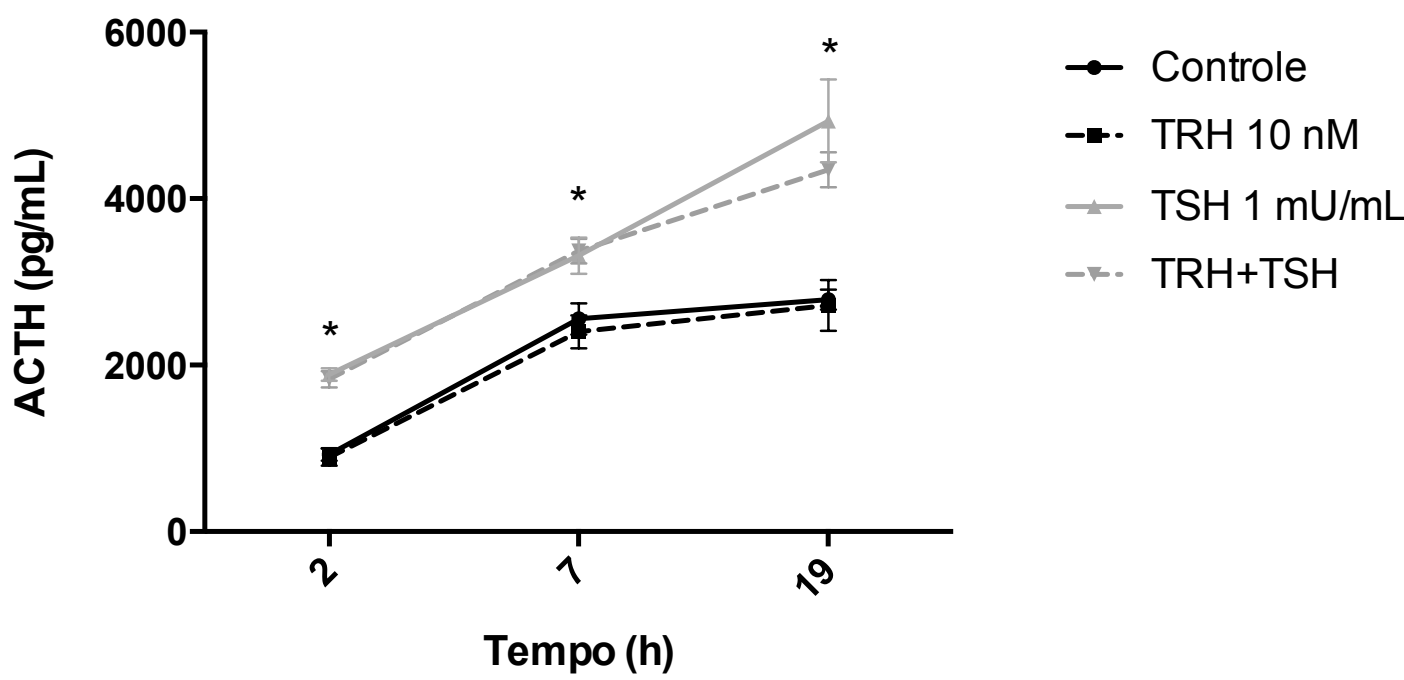

Figura 25 - Avaliação da secreção de ACTH ao longo do tempo (2, 7 e 19 horas) em cultura estática de células hipofisárias tratadas com meio controle (Meio 199 + BSA 0,1\%), TRH $10 \mathrm{nM}$, TSH $1 \mathrm{mU} / \mathrm{mL}$ ou TRH + TSH nas mesmas concentrações citadas anteriormente. ANOVA duas vias seguido pelo teste de comparações múltiplas de Bonferroni ( $p<0,05$ para Controle e TRH $10 \mathrm{nM}$ vs TSH $1 \mathrm{mU} / \mathrm{mL}$ e TRH + TSH no tempo de $2 \mathrm{~h}, \mathrm{p}<0,01$ para Controle e TRH $10 \mathrm{nM}$ vs TSH $1 \mathrm{mU} / \mathrm{mL}$ e TRH + TSH e p<0,001 para Controle e TRH $10 \mathrm{nM}$ vs TSH $1 \mathrm{mU} / \mathrm{mL}$ e TRH + TSH.

Na figura 26 podemos observar o efeito no TSH adicionado em perifusão de células hipofisárias. Nos primeiros 10 minutos ambas câmaras de perifusão foram banhadas com meio controle e a partir do décimo minuto o meio contendo TSH foi adicionado a perifusão da segunda câmara. Após 8 minutos ( $18^{\circ}$ minuto) de tratamento com TSH, a secreção de ACTH já encontrou-se aumentada em relação ao grupo controle. Esse aumento na secreção se mantem durante os minutos restantes de perifusão. 


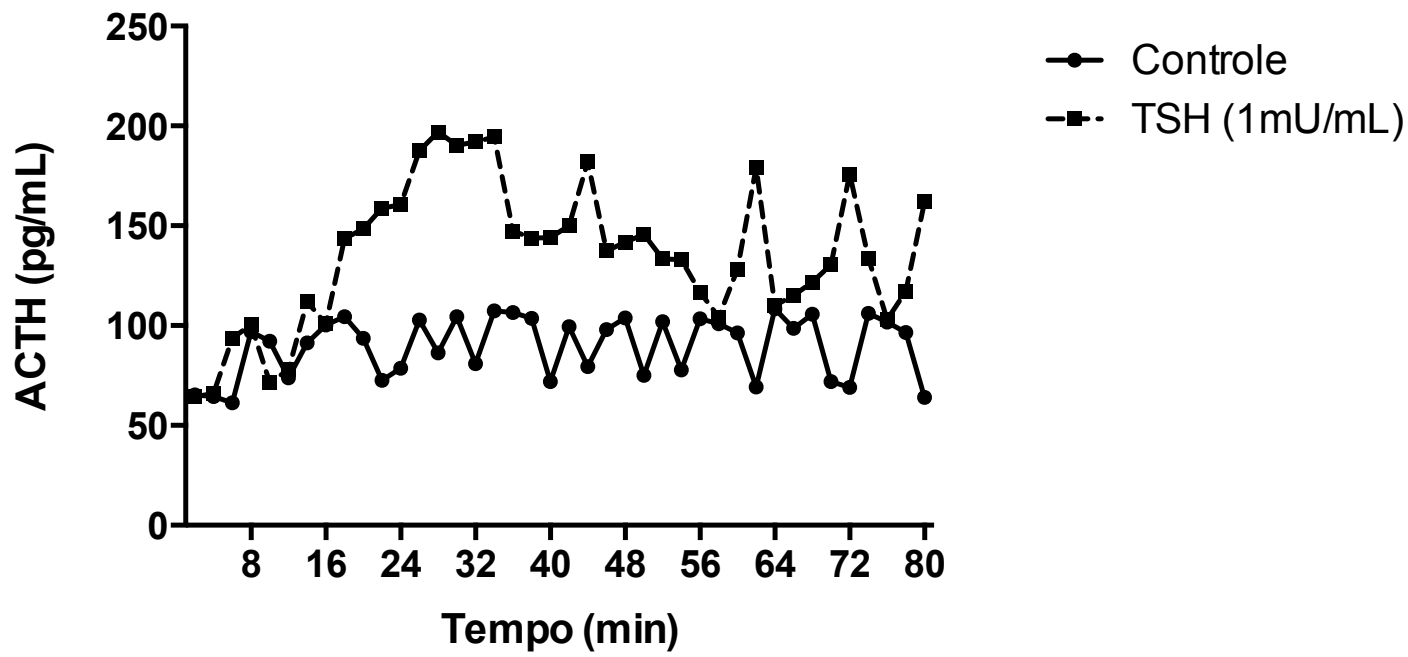

Figura 26 - Secreção de ACTH em células hipofisárias obtidas a partir de cultura primária, aderidas a beads cytodex e perifundidas com meio controle (Meio 199 + BSA 0,1\%) e TSH (Meio $199+$ BSA 0,1\% + TSH $1 \mathrm{mU} / \mathrm{mL}$ ) por 80 minutos a uma velocidade de $0,6 \mathrm{~mL} / \mathrm{min}$.

Após os ensaios de perifusão e secreção estática realizamos ensaios para avaliar se a secreção de ACTH induzida por TSH tinha participação do cálcio (fig. 27). TSH na concentração de $1 \mathrm{mU} / \mathrm{mL}$ provocou aumento no conteúdo intracelular de cálcio em 33 de 45 células analisadas, um total de 73,33\%. CRF e arginina vasopressina (AVP) foram administrados como controle positivo para comprovação de que a célula em questão se tratava de um corticotrofo.

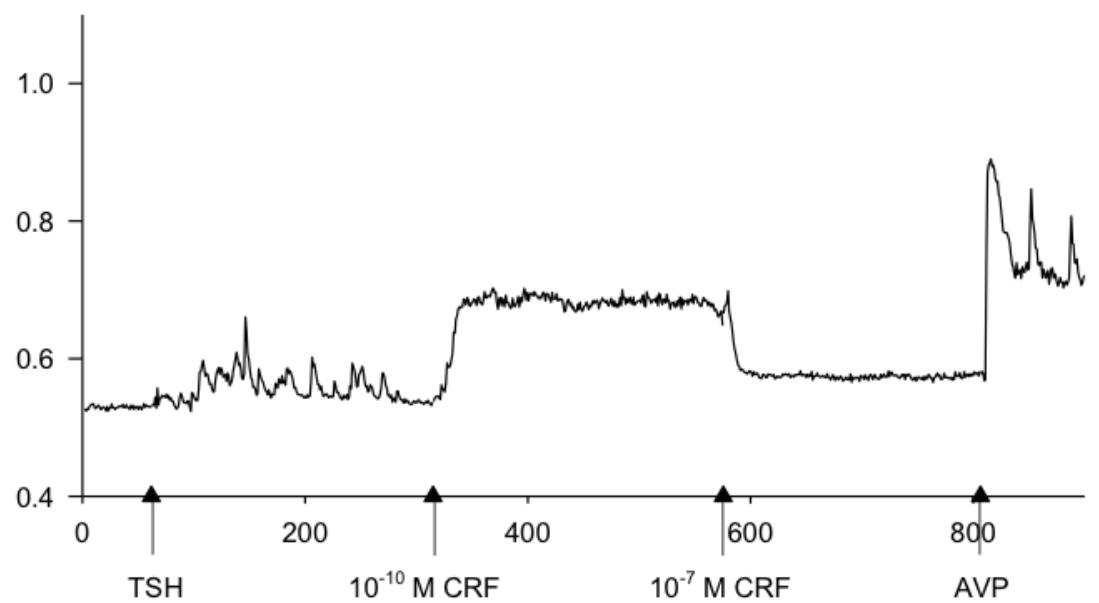

Figura 27 - Fluorescência $\left(F_{340 / 380}\right)$ emitida por células de hipófise após administração de TSH $(1 \mathrm{mU} / \mathrm{mL})$. Aumento de fluorescência (eixo $\mathrm{Y}$ ) corresponde a aumento do conteúdo de cálcio citosólico. CRF $10^{-10} \mathrm{M}$ e $10^{-7} \mathrm{M}$ e AVP $10^{-7} \mathrm{M}$ foram utilizados como controle positivo para identificação de corticotrofos. As unidades do eixo X referem-se ao tempo (s) e as setas indicam o momento em que as drogas foram adicionadas. 
No experimento seguinte (fig. 28) os mesmos tratamentos utilizados anteriormente, aplicação de TSH $(1 \mathrm{mU} / \mathrm{mL}), \operatorname{CRF}\left(10^{-10} \mathrm{M}\right.$ e $\left.10^{-7} \mathrm{M}\right)$ e AVP $\left(10^{-7} \mathrm{M}\right)$ foram repetidos em células pré tratadas com o bloqueador do receptor de $\mathrm{CRH}$, antalarmina, por $5 \mathrm{~min}$. O hormônio TSH manteve seu efeito previamente relatado de mobilizar cálcio para o interior do citosol do corticotrofo, comprovando assim que sua ação não ocorria por ação inespecífica do TSH no receptor de CRF. Esse efeito foi verificado em 3/3 células analisadas.

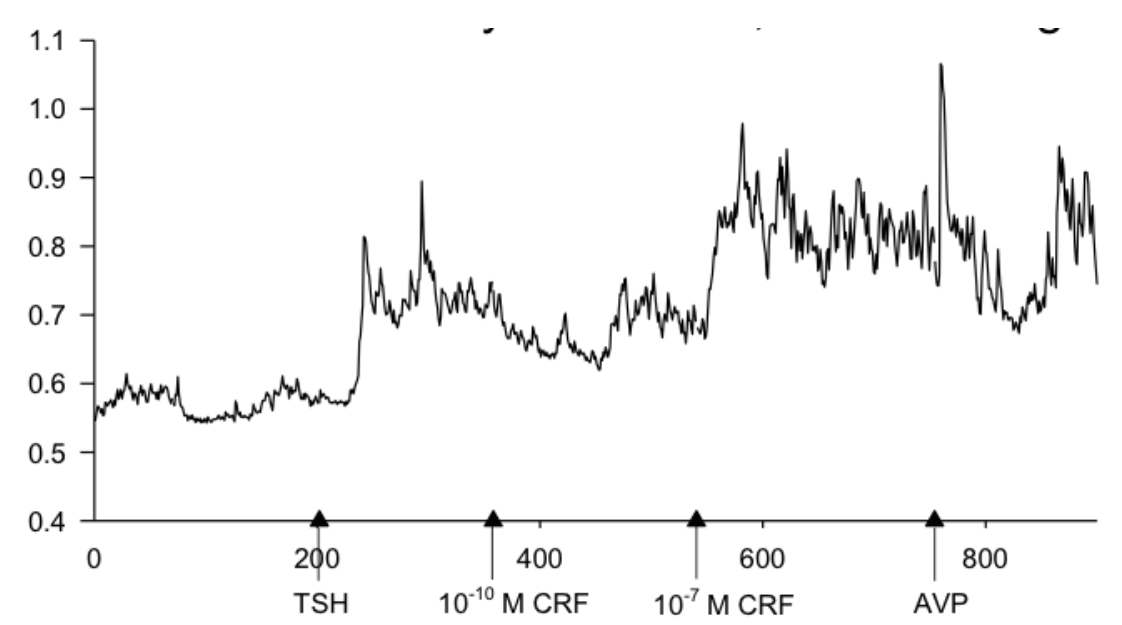

Figura 28 - Fluorescência $\left(F_{340 / 380}\right)$ emitida por células de hipófise de rato pré tratadas por 5 minutos com bloqueador do receptor de CRH antalarmina $\left(5 \times 10^{-7} \mathrm{M}\right)$ antes do tratamento com TSH $(1 \mathrm{mU} / \mathrm{mL})$. Aumento de fluorescência (eixo $\mathrm{Y}$ ) corresponde a aumento do conteúdo de cálcio citosólico. CRF $10^{-10} \mathrm{M}$ e $10^{-7} \mathrm{M}$ e AVP $10^{-7} \mathrm{M}$ foram utilizados como controle positivo para identificação de corticotrofos. As unidades do eixo $\mathrm{X}$ referem-se ao tempo (s) e as setas indicam o momento em que as drogas foram adicionadas.

Após os experimentos de medida de cálcio, testamos se o tratamento com TSH por 0,1 , 2, 4 e 6 h provocaria alterações na quantidade de AMPc produzida pelas células hipofisárias. Constatamos no meio de cultura de células tratadas com TSH, que após 4 e 6 h ocorreu um aumento na quantidade de AMPc produzido (fig. 29). Já no conteúdo intracelular, não detectamos alterações na quantidade de AMPc presente entre o grupo controle e o tratado com TSH (fig. 30). 


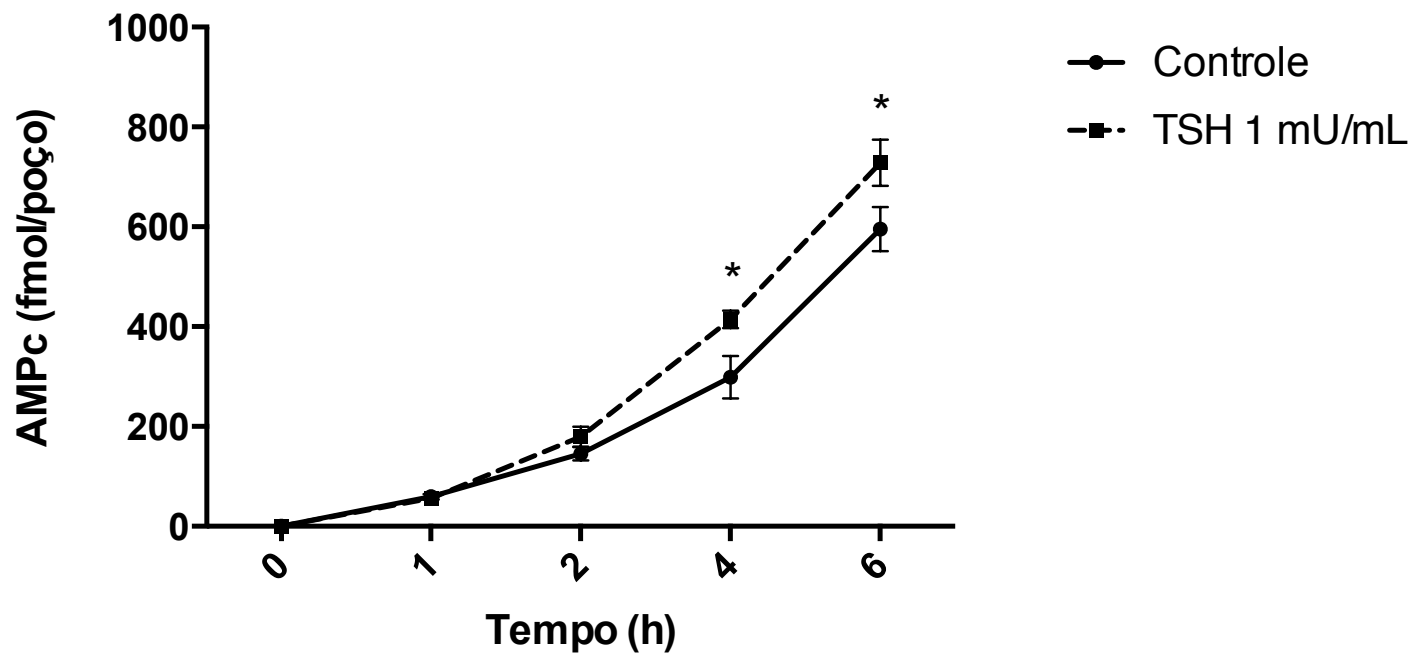

Figura 29 - Efeito do tratamento com TSH na concentração de AMPc em meio de cultura ao longo do tempo (0, 1, 2, 4 e 6 $h)$ medido por RIA em cultura primária de células de hipófise $(n=4)$. ANOVA duas vias seguido pelo teste de comparações múltiplas de Bonferroni ( $p<0,05$ para Controle 4 h vs TSH 4 h e para Controle 6 h vs TSH 6 h).

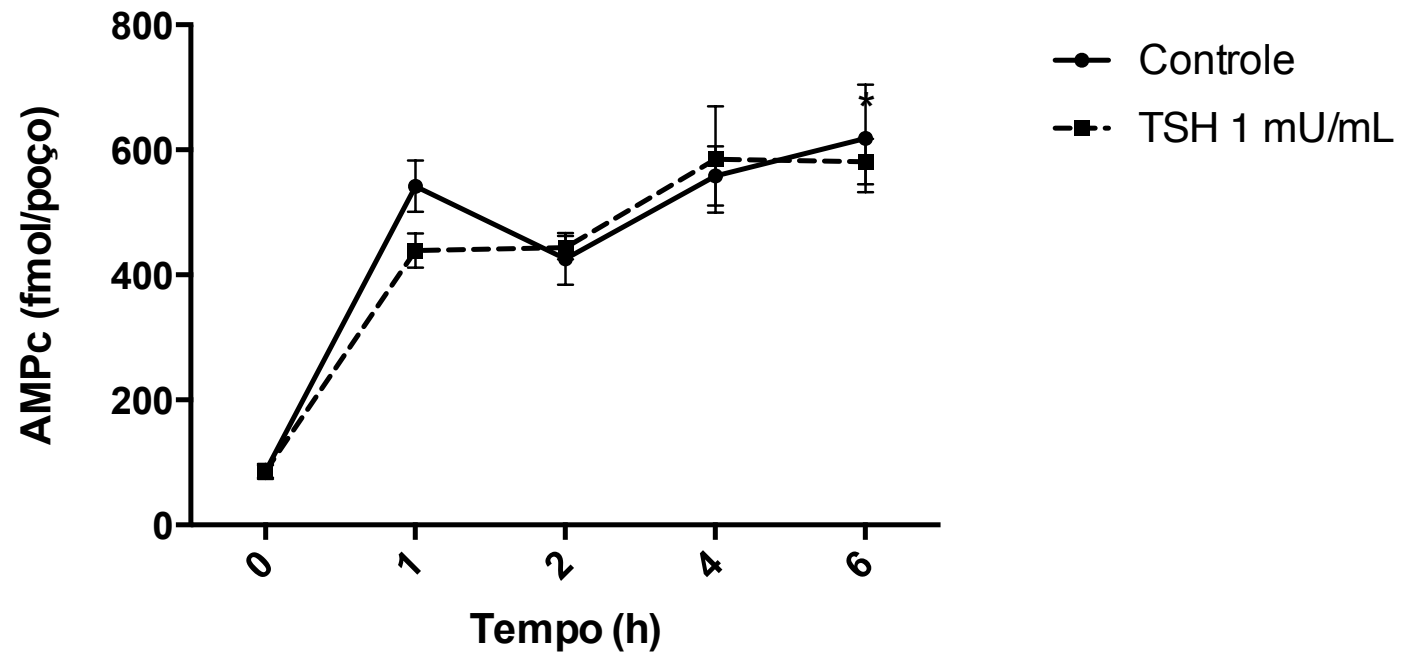

Figura 30 - Efeito do tratamento com TSH na concentração de AMPc intracelular ao longo do tempo (0, 1, 2, 4 e 6 h) medido por RIA em cultura primária de células de hipófise $(n=4)$. ANOVA duas vias seguido pelo teste de comparações múltiplas de Bonferroni. 


\subsubsection{Cultura primária de glândula adrenal}

Na figura 31 observamos o efeito do tratamento com T3 em duas doses $\left(10^{-7}\right.$ e $\left.10^{-9} \mathrm{M}\right)$ na expressão gênica do fator esteroidogênico 1 (SF-1) em cultura primária de adrenais. As células foram mantidas em meio DMEM contendo $0,5 \%$ de soro fetal bovino por $24 \mathrm{~h}$ antes do tratamento com $\mathrm{T} 3$ por $4 \mathrm{~h}$. O hormônio tireoidiano na dose $10^{-7} \mathrm{M}$ aumentou a expressão gênica de SF-1 em relação ao grupo tratado apenas com SFB 0,5\% por 24 h e o mesmo efeito ocorreu quando comparamos o grupo tratado com o grupo controle.

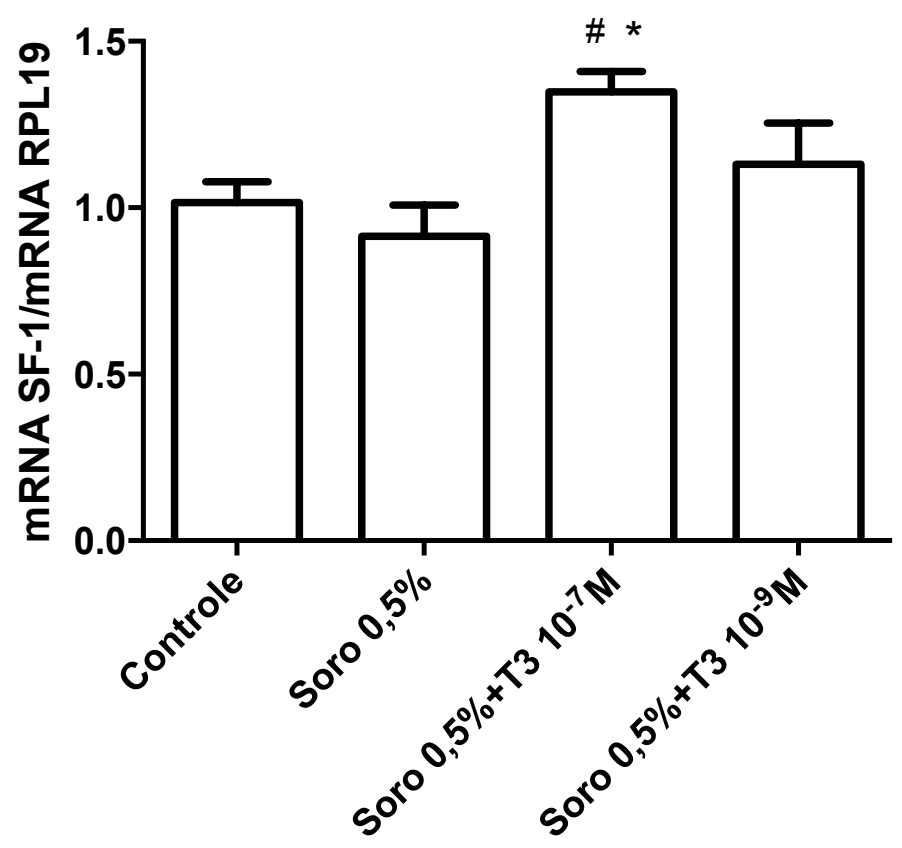

Figura 31 - Avaliação da expressão gênica da enzima SF1 por qPCR em cultura primária de adrenais ( $\mathrm{n}=8$ ) tratadas com meio controle (DMEM + SFB 10\%), Soro 0,5\% (DMEM + SFB 0,5\%), Soro 0,5\% + $\mathrm{T}_{3} 10^{-7} \mathrm{M}$ e Soro $0,5 \%+T_{3} 10^{-9} \mathrm{M}$. As células foram tratadas com Soro 0,5\% por 24 horas e após este tempo com T3 nas concentrações citadas por 4 horas. ANOVA unifatorial seguido pelo teste de comparações múltiplas de Newman-Keuls $\left(p<0,05\right.$ para controle vs Soro $0,5 \%+$ T3 $10^{-7} \mathrm{M}$ e $\mathrm{p}<0,05$ para Soro $0,5 \%$ vs Soro $0,5 \%+\mathrm{T} 310^{-7} \mathrm{M}$ ).

Avaliamos também a expressão do RNA mensageiro de enzimas envolvidas no processo de esteroidogênese como CYP11B1, StAR, 3ß-HSD e do receptor de melanocortina Mc2R (fig. 29). O tratamento com $\mathrm{T} 3$ em nenhuma das doses utilizadas provocou alteração na expressão das enzimas citadas e nem do receptor de ACTH. 

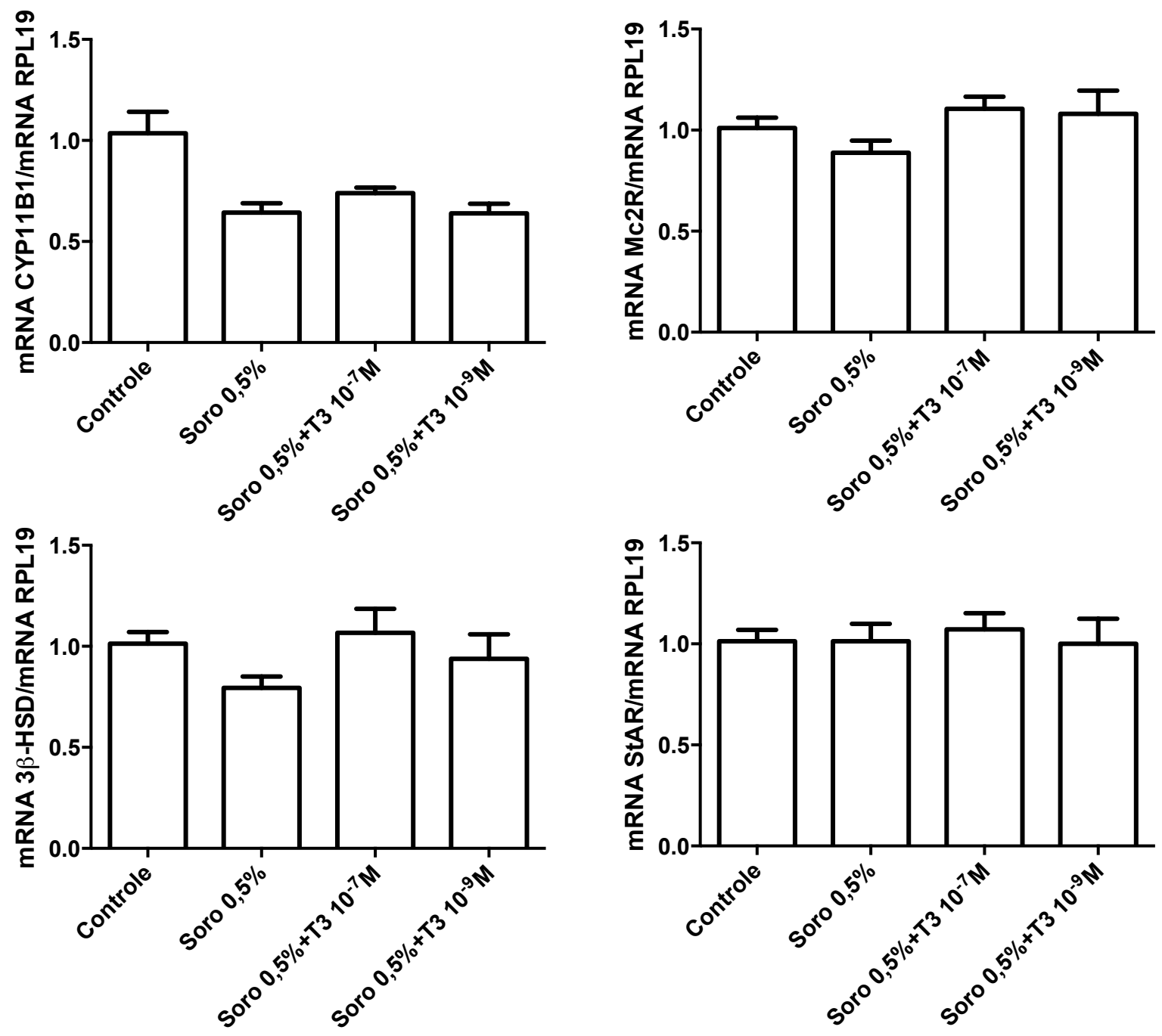

Figura 32 - Avaliação da expressão gênica das enzimas CYP11B1, 3ß-HSD e StAR e do receptor de melanocortina Mc2R por qPCR em cultura primária de adrenais $(n=8)$ tratadas com meio controle (DMEM+SFB 10\%), Soro 0,5\% (DMEM+SFB $0,5 \%$ ), Soro $0,5 \%+T_{3} 10^{-7} \mathrm{M}$ e Soro $0,5 \%+T_{3} 10^{-9} \mathrm{M}$. As células foram tratadas com Soro $0,5 \%$ por 24 horas e após este tempo com T3 nas concentrações citadas por 4 horas. ANOVA unifatorial seguido pelo teste de comparações múltiplas de NewmanKeuls.

\subsubsection{Cultura de células AtT-20}

Antes do início dos experimentos com a linhagem AtT-20, foram realizados testes de padronização para escolha do período de tempo mais adequado de manutenção das células em meio depletado de hormônio tireoidiano (fig. 33) e testes para avaliação da concentração de T3 a ser utilizada (fig. 34) nos experimentos seguintes. O tempo escolhido a partir do primeiro teste foi o de 24 h de depleção de hormônio tireoidiano por apresentar a maior queda de expressão gênica da POMC entre os tempos avaliados avaliada estatisticamente. Em relação à concentração de $\mathrm{T} 3$, optamos pela utilização da concentração de $10^{-9} \mathrm{M}$, por ser a dose que 
provocou nas células depletadas de HTs um aumento de expressão gênica a valores iguais aos do grupo controle, e elegemos a dose $10^{-7} \mathrm{M}$ como dose supra fisiológica de T3 para as células AtT-20.

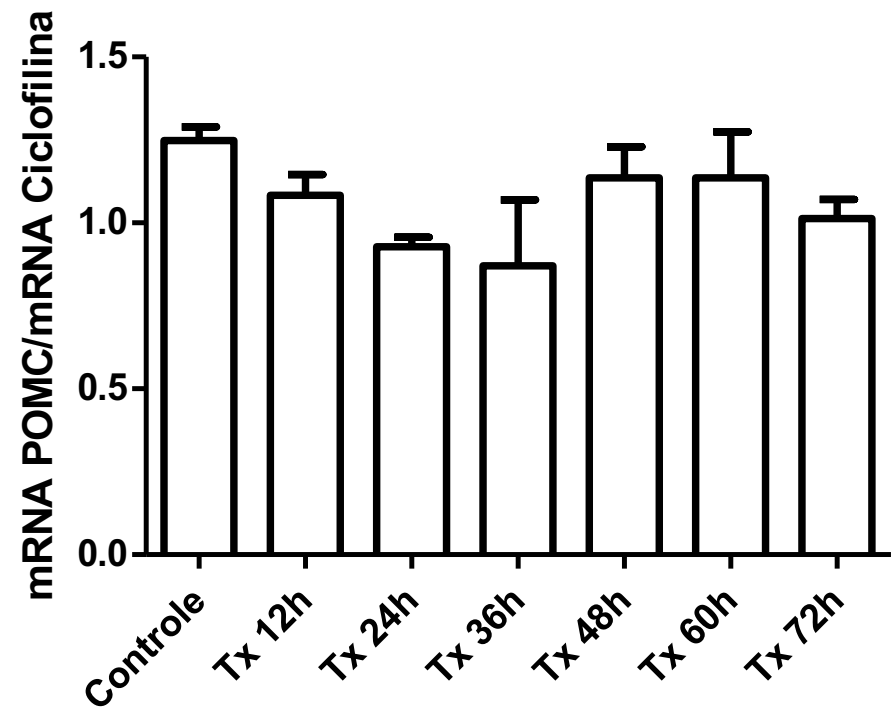

Figura 33 - Avaliação da expressão gênica da proopiomelanocortina em células AtT-20 ( $n=6)$ ao longo de diferentes tempos de depleção de hormônio tireoidiano do meio de cultura para estabelecimento do tempo utilizado nos procedimentos de cultura celular. ANOVA unifatorial seguido pelo teste de comparações múltiplas de Newman-Keuls.

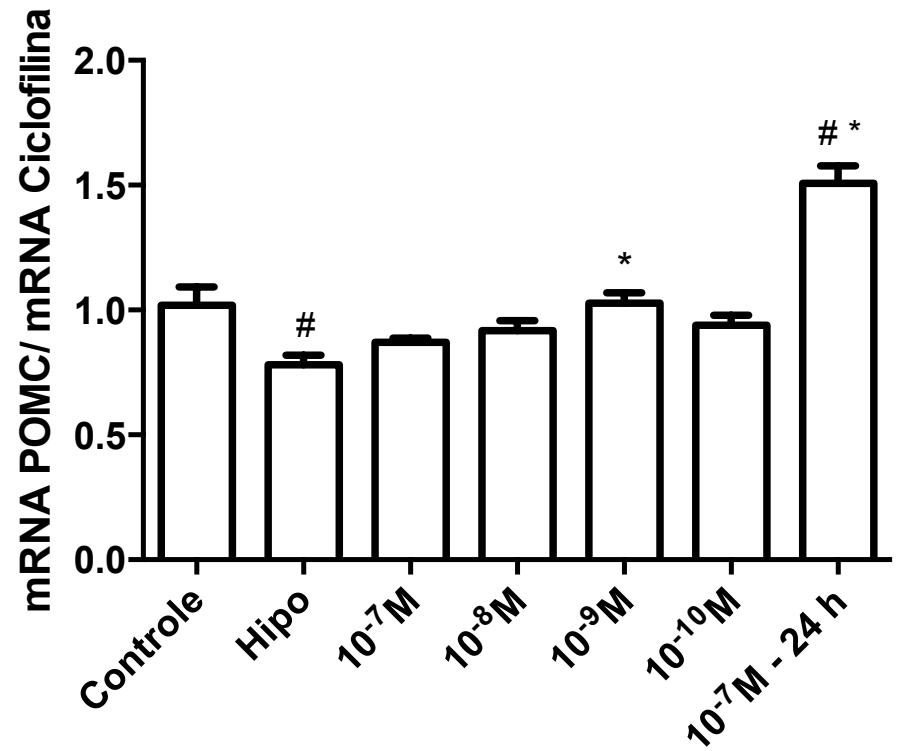

Figura 34 - Avaliação da expressão gênica da proopiomelanocortina em células AtT-20 (n=6) por qPCR após 24 h de tratamento com soro depletado de hormônio tireoidiano (Hipo) seguido por reposição de meia hora do hormônio nos tratamentos $10^{-7} \mathrm{M}, 10^{-8} \mathrm{M}, 10^{-9} \mathrm{M}$ e $10^{-10} \mathrm{M}$ e por $24 \mathrm{~h}$ no grupo crônico (T3 $\left.10^{-7} \mathrm{M}\right)$. ANOVA unifatorial seguido pelo teste de comparações múltiplas de Newman-Keuls, ( $p<0,05$ para Controle vs Hipo e Hipo vs $10^{-9} \mathrm{M}$ e $p<0,001$ para Controle e Hipo vs $10^{-7} \mathrm{M}-24 \mathrm{~h}$ ). 
Para encerrar as padronizações, realizamos um teste de integridade de membrana para averiguar se o tratamento com soro depletado de HTs seria nocivo para as células AtT-20. Nas figuras 35 e 36 mostramos, respectivamente, a fluorescência emitida por células cultivadas com SFB controle e por células tratadas com SFB depletado de HTs. A porcentagem média de sobrevivência de células na passagem $11(\mathrm{n}=3)$ foi de $99,77 \%$ e 99,89\% para as células controle e para as células tratadas com soro depletado, respectivamente. Já na passagem 12 (n=3), a sobrevivência foi de 99,94\% para as células controle e de $99,81 \%$ para as células tratadas com soro depletado. Portanto, não existe perda de viabilidade celular causada pelo tratamento com soro depletado de HTs.

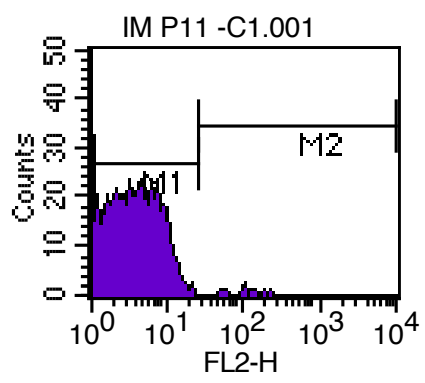

File: IM P11 -C1.001

\begin{tabular}{rrr} 
Marker & Events & $\%$ Gated \\
\hline All & 4694 & 100.00 \\
M1 & 4682 & 99.74 \\
M2 & 12 & 0.26
\end{tabular}

Figura 35 - Avaliação por citometria de fluxo da integridade de membrana de células AtT-20 na passagem 11 tratadas com soro fetal bovino. Células com membrana íntegra emitem baixa fluorescência, já que o iodeto de propídio não penetra e se intercala no DNA dessas células. Eixo $X$ representa a fluorescência e o eixo $Y$ a contagem de eventos.

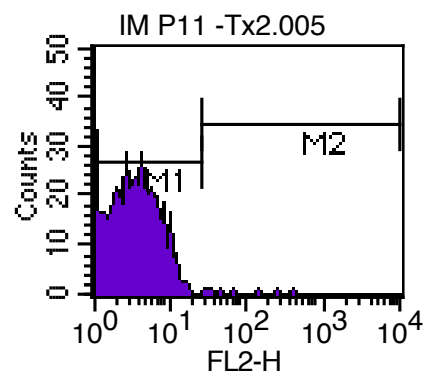

File: IM P11 -Tx2.005

\begin{tabular}{rrr} 
Marker & Events & $\%$ Gated \\
\hline All & 4599 & 100.00 \\
M1 & 4590 & 99.80 \\
M2 & 9 & 0.20
\end{tabular}

Figura 36 - Avaliação por citometria de fluxo da integridade de membrana de células AtT-20 na passagem 11 tratadas com soro fetal bovino. Células com membrana íntegra emitem baixa fluorescência, já que o iodeto de propídio não penetra e se intercala no DNA dessas células. Eixo $\mathrm{X}$ representa a fluorescência e o eixo $\mathrm{Y}$ a contagem de eventos.

Padronizadas as condições experimentais, partimos para o estudo em que avaliamos o efeito da administração aguda (30 min) de T3 sobre a expressão gênica da POMC, na presença 
ou não de actinomicina D (bloqueador da expressão gênica), conforme apresentado na figura 37.

Verificou-se que as células mantidas em meio depletado de T3 apresentaram menor expressão do mRNA da POMC vs grupo controle, reiterando nossos estudos in vivo, e que o $\mathrm{T} 3$, na concentração $10^{-9} \mathrm{M}$, rapidamente aumenta a expressão do gene da POMC, efeito que é parcialmente perdido quando as células são tratadas com actinomicina $\mathrm{D}$ e recebem hormônio nesta mesma concentração. Esse dado aponta para uma ação rápida do T3 por via não genômica e também por via genômica, já que o bloqueio da transcrição gênica atenuou o aumento do conteúdo de mRNA da POMC observado após 30 min da administração do T3. Nota-se que o efeito agudo do T3 sobre a expressão desse gene não é evidenciado quando doses suprafisiológicas são utilizadas $\left(10^{-7} \mathrm{M}\right)$ por $30 \mathrm{~min}$. Esses dados, em conjunto, sugerem que as ações não genômicas do T3 fazem parte de uma regulação fisiológica da expressão desse gene, pois são desencadeadas com a menor dose de T3.

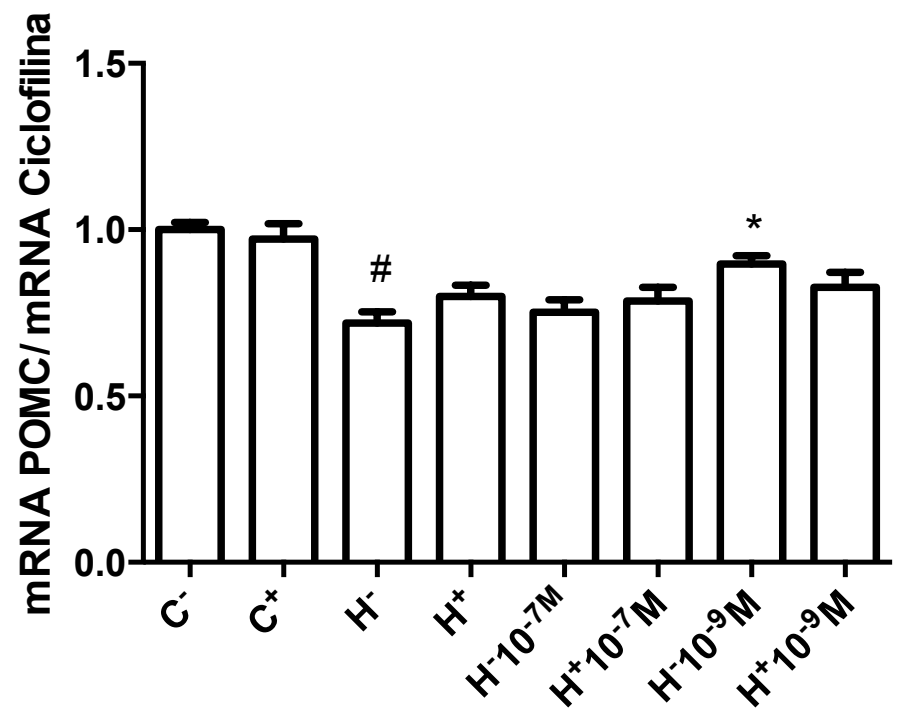

Figura 37 - Avaliação da expressão gênica da proopiomelanocortina em células AtT-20 ( $n=6)$ na presença (+) e ausência (-) de actinomicina $D$ e tratadas ou não com T3 nas concentrações $10^{-7} \mathrm{M}$ e $10^{-9} \mathrm{M}$. ANOVA unifatorial seguido pelo teste de comparações múltiplas de Newman-Keuls, ( $p<0,01$ para $\mathrm{C}^{-}$vs $\mathrm{H}^{-}$e $\mathrm{p}<0,05$ para $\mathrm{H}^{-}$vs $\mathrm{H}^{-} 10^{-9} \mathrm{M}^{-} \mathrm{H}^{+} 10^{-9} \mathrm{M}=\mathrm{H}^{-} 10^{-9} \mathrm{M}$ ).

Conforme colocado anteriormente, algumas ações não genômicas do T3 são desencadeadas após sua interação com uma integrina de membrana, a $\alpha \mathrm{V} \beta 3$, que reconhece proteínas com domínio RGD e também os HTs. Realizamos verificação da expressão por qPCR (fig. 38) das duas subunidades da integrina, $\alpha \mathrm{V}$ e $\beta 3$, para confirmar a sua expressão nas células 
AtT-20 e demos continuidade ao estudo. A figura 39 mostra o experimento em que células AtT20 foram cultivadas na presença ou não de T3, do peptídeo RGD ou RGE (controle negativo).

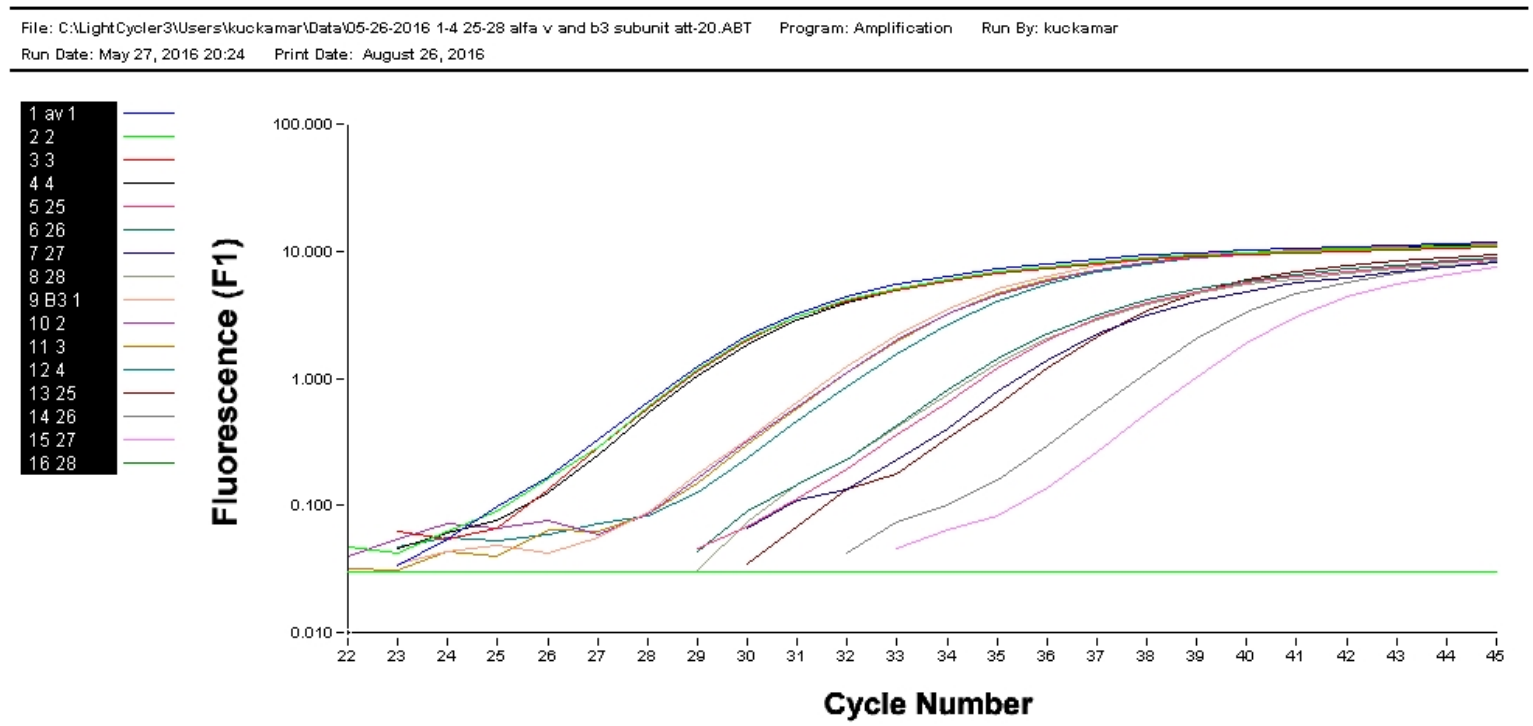

Figura 38 - Verificação por qPCR da presença do mRNA das duas subunidades da integrina de membrana, $\alpha$ V e $\beta 3$. Sondas Taqman para as subunidades $\alpha \mathrm{V}$ e $\beta 3$ foram adquiridas da Applied Biosystems para esta identificação.

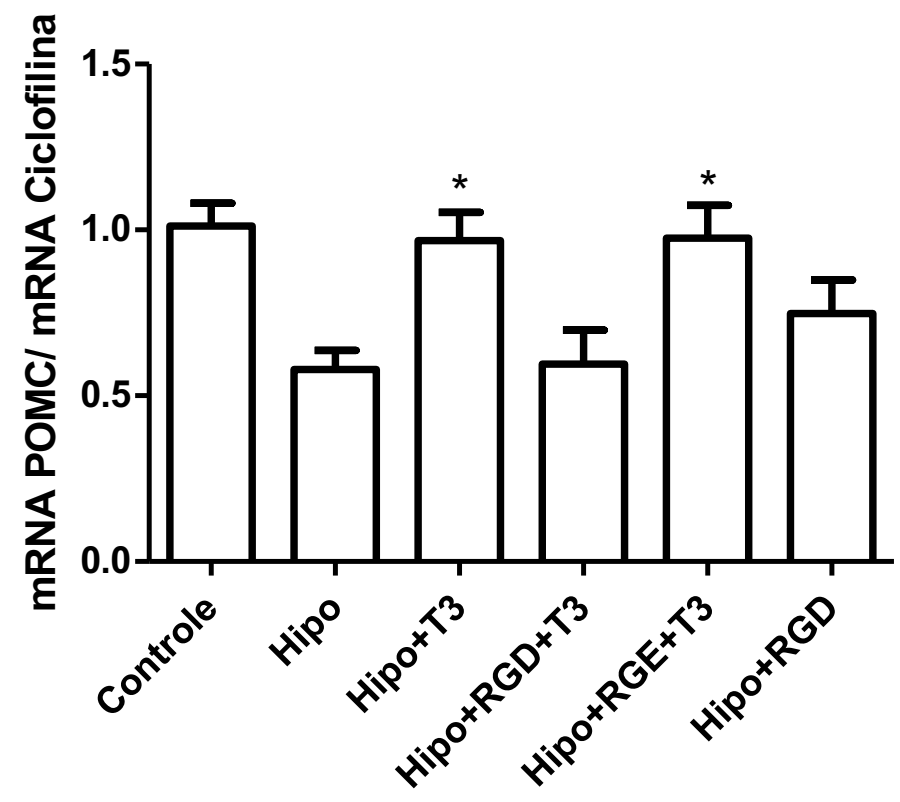

Figura 39 - Avaliação da expressão gênica da proopiomelanocortina em células AtT-20 ( $n=6$ ) após 24 h de tratamento com soro depletado de hormônio tireoidiano, com posterior adição de RGD e RGE por $\mathbf{3 0}$ min, seguida por reposição de meia hora de T3 na concentração $10^{-9} \mathrm{M}$. ANOVA bifatorial seguido pelo teste de comparações múltiplas de Bonferroni, ( $p<0,05$ para Hipo+T3 vs Hipo e para Hipo+RGE+T3 vs Hipo+RGD+T3). 
Neste experimento observamos que o aumento da expressão gênica da POMC causado pelo tratamento agudo com T3 foi abolido quando o RGD foi utilizado; contudo o efeito de T3 se manteve quando, em vez de RGD, as células foram tratadas com RGE.

Esses dados confirmam a ação rápida, não genômica, do T3 sobre a expressão desse gene, além de apontar que, ao menos parte dessa ação depende da interação do T3 com o sítio da integrina $\alpha \mathrm{V} \beta 3$, que reconhece o domínio RGD. 


\section{DISCUSSÃO}

Sabe-se que na hipófise o hormônio tireoidiano age nos somatotrofos regulando positivamente o gene do GH (MURPHY et al., 1992), e nos tireotrofos reprimindo a expressão do gene do TSH (STATON et al., 1998). Porém, há escassez de dados moleculares consistentes a respeito da regulação exercida pelo T3, nos corticotrofos, sobre o gene da POMC. Neste estudo apresentamos evidências de que os HTs regulam mecanismos transcricionais e pós transcricionais envolvidos na síntese de POMC e ACTH.

A redução da expressão gênica da POMC nos animais tireoidectomizados, bem como nas células cultivadas em meio depletado de T3, indica que a presença do T3 é necessária para a expressão basal desse gene. Esse dado contrasta com os de Johnson et al. 2012, que não observaram qualquer alteração no conteúdo do mRNA da POMC na hipófise de animais tireoidectomizados. No estudo citado, a avaliação da expressão gênica da POMC se deu por hibridização in situ, técnica considerada bem menos sensível para detecção de conteúdo de mRNA que o qPCR. Contudo, devemos ressaltar que nos diferentes experimentos desenvolvidos no presente estudo houve uma consistência de redução da expressão desse transcrito nos animais/células hipotireoideos vs eutireoideos. Por outro lado, observamos que apenas concentrações supra-fisiológicas de T3 foram capazes de aumentar o conteúdo do mRNA da POMC nos ratos Tx e a valores menores que o grupo controle, sugerindo uma menor resposta do corticotrofo ao T3 quando ocorre instalação do hipotireoidismo. Johnson e colaboradores, 2012, verificaram que hipotálamos explantados de ratos com 60 dias de hipotireoidismo em cultura produzem menos CRH do que os hipotálamos controles. Como o CRH é o mais importante fator estimulante da expressão de mRNA da POMC (TSIGOS; CHROUSOS, 2002), provavelmente essa queda na expressão do mRNA da POMC detectada em nosso estudo se deve também a uma redução de CRH sendo liberado pelo hipotálamo desses animais. Além disso, estudo prévio do nosso laboratório demonstrou que o citoesqueleto da hipófise se encontra desarranjado em animais hipotiroideos (SILVA et al., 2006). Sabe-se que esse desarranjo pode prejudicar a transcrição de genes devido a um funcionamento inadequado do complexo de iniciação da RNA polimerase do tipo 2 (GETTEMANS et al., 2005).

Os resultados de conteúdo proteico de POMC e ACTH indicam que, apesar do conteúdo de mRNA se apresentar reduzido nos animais tireoidectomizados, existem mecanismos compensatórios ativados para manutenção do conteúdo de POMC e ACTH na glândula dentro 
da normalidade. O comprimento da cauda poli(A) do RNA mensageiro é um fator que pode interferir na expressão gênica por afetar a estabilidade, o transporte e o início da tradução do RNA em questão (ZHANG; VIRTANEN; KLEIMAN, 2010). No experimento in vivo agudo, o aumento de cauda poli(A) do transcrito da POMC verificado no grupo tireoidectomizado acaba tornando este RNA mais estável, apesar dele se apresentar em menor conteúdo. Este pode ser um mecanismo de contrabalanço ativado para manter a expressão gênica da POMC apesar dos níveis baixos de seu RNA mensageiro. Existem diversos relatos de regulação da cauda poli(A) pelos HTs, onde estes podem causar tanto aumento (LIU; WAXMAN, 2002; MURPHY, et al., 1992; ROMANO, et al., 2013), como redução (GOULART-SILVA; DE SOUZA; KRANE; SPINDEL; CHIN, 1991; NUNES, 2011) do comprimento da cauda poli(A). Vale comentar que o aumento no comprimento de cauda poli(A) ocorre, em geral, em transcritos de genes que são regulados positivamente por um ligante, quando os mesmos se encontram na ausência deste, o que reforça o dado de que os HTs atuam fisiologicamente induzindo a expressão do gene da POMC (MURPHY, et al., 1992). O fato de que o hormônio tireoidiano, em ambas as doses, rapidamente induz a diminuição do comprimento da cauda poli(A) em ambos os grupos tireoidectomizados, também é uma indício que reitera nossa hipótese de que os HTs são necessários para que o gene da POMC seja transcrito.

Os dados obtidos com o ensaio de perfil polissomal mostram uma maior quantidade de moléculas de mRNA da POMC ligadas aos ribossomos, o que sugere maior taxa de tradução do transcrito em animais hipotiroideos vs eutiroideos, o que corrobora a hipótese de que mecanismos compensatórios são acionados na tentativa de manutenção de POMC e ACTH, uma vez que o conteúdo de mRNA de POMC estava reduzido. T3 já se mostrou capaz de modular a ligação de mRNA aos polissomos em outros tipos celulares da hipófise, como nos tireotrofos, onde reduziu a tradução de TSH $\beta$ (GOULART-SILVA; DE SOUZA; NUNES, 2011) e nos somatotrofos, aumentando a taxa de tradução do mRNA do GH (GOULARTSILVA et al., 2010), ações essas que podem ser correlacionadas com o tamanho da cauda poli(A) dos mRNAs estudados, assim como ocorre no nosso estudo. Somando-se a tradução aumentada do mRNA da POMC em ratos hipotiroideos, temos o aumento da expressão gênica da enzima PC1, que é de fundamental importância para a clivagem da POMC e liberação de ACTH da sua molécula (BENJANNET et al., 1991).

Nota-se que após a regulação exercida por todos os mecanismos citados anteriormente, o conteúdo de POMC e ACTH não se encontraram alterados nos grupos estudados, porém os níveis circulantes de ACTH estão reduzidos em animais Tx, parâmetro esse revertido pelo 
tratamento com T3. Essa redução na secreção de ACTH pode ser explicada pela redução na secreção de CRH no hipotálamo de ratos tireoidectomizados (JOHNSON, et al., 2012). Nosso trabalho mostra que o tratamento com T3 regula a secreção de $\mathrm{ACTH}$, possivelmente por normalizar a secreção de CRH dos animais tireoidectomizados tratados com T3. Além disso, verificamos se o T3 seria um hormônio com importante papel na secreção de ACTH. Para solucionar essa questão realizamos experimentos com cultura primária de hipófises e tratamos essa cultura com T3 em diferentes doses e após 1 e 4 h de tratamento, não detectamos nenhuma alteração na secreção de ACTH. Teste com tempos de 24 e 48 h de estimulação também foi realizado e não houve aumento de secreção (dados não mostrados). Não podemos deixar de mencionar novamente o desarranjo no citoesqueleto na hipófise de animais Tx (SILVA, et al., 2006), onde foi detectada redução na secreção de GH e o T3 promoveu aumento da síntese e secreção de GH graças a um rearranjo do citoesqueleto de actina nos somatotrofos. É possível que os corticotrofos também estejam com seu citoesqueleto comprometido, causando assim redução na secreção de $\mathrm{ACTH}$ e que o tratamento com $\mathrm{T} 3$ poderia estar causando um rearranjo desse citoesqueleto, melhorando a secreção de $\mathrm{ACTH}$, como também aumentando a secreção de CRH pelo hipotálamo.

Observamos também uma expressão aumentada de mRNA do CRH nos grupos Tx tratados cronicamente com ambas as doses de T3. O fato de, nessas condições não termos um aumento equivalente do mRNA da POMC sugere uma ação diferencial do T3 no hipotálamo e hipófise, o que merece ser investigado futuramente, já que o hipotálamo desses animais parece estar hiper-reativo ao tratamento, mas sem uma resposta final esperada. Sabe-se que a expressão de CRH no hipotálamo sofre influência de vários fatores, como interleucinas, acetilcolina e serotonina, que aumentam sua expressão, e dos glicocorticoides que são responsáveis pelo feedback negativo (CALOGERO et al. 1988; FULLER, 1992; SAPOLSKY, 1997). Estudos futuros que busquem a compreensão de possíveis alterações desses neurotransmissores no hipotireoidismo podem vir a esclarecer essa questão, já que a corticosterona não se mostrou alterada em nossos grupos estudados.

Chama a atenção no trabalho de Johnson et al., 2013 a hipercorticosteronemia detectada em animais tratados com $50 \mu \mathrm{g}$ de T4 por 7 ou 60 dias, acompanhada de um aumento de mRNA da POMC na hipófises dos ratos tratados com T4 por 7 dias, porém sem alterações nas concentração de ACTH sérico. Constatamos que o tratamento com T3 por 4 horas em cultura primária de adrenal regula positivamente o receptor nuclear SF-1, um importante estimulador da esteroidogênese (HOIVIK et al., 2010; LUO; IKEDA; PARKER, 1994), o que pode explicar 
o aumento da corticosterona nesses animais, ainda mais que estes foram tratados com T4 por um longo período. Em nosso trabalho não detectamos alterações nas concentrações séricas de corticosterona, fato também relatado por Johnson et al., 2012 em cultura primária de adrenais retiradas de ratos tireoidectomizados por 7 dias. Acreditamos que a sensibilidade ao ACTH nessas adrenais esteja aumentada, e que talvez, se a tireoidectomia fosse mantida por um tempo maior do que 20 dias encontraríamos uma redução na corticosterona sérica, assim como se esses animais fossem submetidos a algum agente estressor, eles poderiam ter uma resposta reduzida ao agente estressor.

O peso das adrenais mostrou-se reduzido nos animais tireoidectomizados e o tratamento com dose suprafisiológica T3 foi capaz de reestabelecer o peso a valores iguais ao de animais controles. Sabe-se que o ACTH exerce ação trófica nas glândulas adrenais (HORNSBY, 1985) e que alterações em suas concentrações podem alterar o peso da glândula. Como esperado, o ACTH sérico de nossos animais encontrou-se reduzido e seus níveis foram elevados pelo tratamento com HT, o que condiz com o aumento no peso das adrenais. Apesar de não termos encontrado efeito do T3 na expressão do receptor de ACTH (Mc2R) e nas enzimas envolvidas

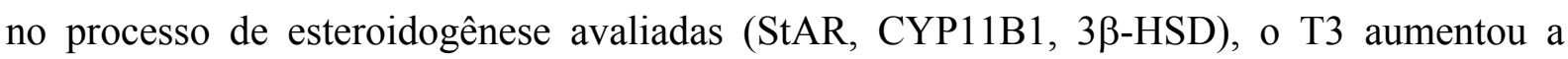
expressão de SF-1, um potente modulador da esteroidogênese e do desenvolvimento da adrenal, mostrando que o T3 pode indiretamente interferir na esteroidogênese.

Um outro fator alterado no eixo hipotálamo-hipófise-tireóide no hipotireoidismo são os níveis séricos de TRH e TSH, que se encontram aumentados na ausência de T4 e T3 (YEN, 2001; ZOELLER; TAN; TYL, 2007). Por isso, realizamos experimentos com cultura primária de hipófises para verificar possíveis ações do TRH e do TSH no corticotrofo. Outros trabalhos já verificaram a presença do receptor de TSH (TSHR) na hipófise de humanos, mais particularmente nas células folículo estreladas (PRUMMEL et al., 2000) e na hipófise do rato (BROKKEN et al., 2001). Mesmo com essas informações confirmamos a expressão do RNAm do TSHR, já que a expressão de alguns genes pode se encontrar alterada pelo processo de dissociação do tecido hipofisário (BARGI-SOUZA et al., 2015). Em relação ao TRH, não houve alterações na secreção de ACTH quando as células hipofisárias foram tratadas com este hormônio, já o TSH promoveu aumento de secreção de ACTH pelos corticotrofos. Sabe-se que existem diversas relações parácrinas na hipófise (DENEF, 2008). Nos corticotrofo um fator clássico que participa na potencialização da ação do CRH na secreção de ACTH é a arginina vasopressina (AVP) (GILLIES; LINTON; LOWRY, 1982), sem alterar a expressão gênica de POMC (KEVIN; BLUM; ROBERTS, 1989). Outro fator parácrino estimulador da produção de 
ACTH são as urocortinas, que nos humanos são produzidas principalmente nos somatotrofos e em menor proporção nos lactotrofos (DENEF, 2008; WONG et al., 1996). No nosso trabalho demonstramos pela primeria vez um novo fator parácrino estimulante da secreção de ACTH, o TSH. Sabe-se que as células folículo estreladas são um elo entre o sistema imune e o sistema endócrino sendo responsáveis pela produção de interleucina-6, que é um fator estimulante da secreção de ACTH (RENNER, et al., 1998; RIVIER, 2001). Para verificar os mecanismos envolvidos na secreção de ACTH induzida por TSH e se este estaria agindo nos corticotrofos, ou se na verdade ele estaria se ligando ao receptor presente nas células folículo estreladas (PRUMMEL et al., 2000), realizamos experimentos para medir a produção de AMPc e a mobilização de cálcio para o citosol, uma vez que o TSH estimula tanto Gs como Gq (DUPREZ et al., 1998; RICHARDS, 2008).

O TSH provocou aumento de AMPc no meio de cultura das células estudadas, além de $73,33 \%$ dos corticotrofos analisados terem apresentado aumento de cálcio citosólico após a administração de TSH. Na hipófise, a estimulação de Gs provoca aumento de AMPc, que é responsável tanto por uma ativação direta de canais que provocam aumento de cálcio intracelular, como ativação indireta desses canais, mediada pela fosforilação por PKA. Já a estimulação de Gq causa formação de IP3, que se liga em seus receptores presentes no retículo endoplasmático provocando liberação de cálcio para o citosol (STOJILKOVIC, 2012; STOJILKOVIC; TABAK; BERTRAM, 2010). O aumento de cálcio nos corticotrofos nos leva a crer que estes também possuem TSHR, uma vez que esse efeito é compatível com a estimulação de Gs e Gq por TSH, e que a IL-6 não provoca alterações no conteúdo de AMPc e cálcio citosólicos (KISHIMOTO, 2010). Porém, com o presente experimento ainda não podemos afirmar se o aumento de cálcio no citosol é proveniente do meio extra celular, do retículo ou de ambos. Futuramente realizaremos experimentos com meio deficiente de cálcio para esclarecer essa questão. Além disso, não descartamos a possibilidade de que o TSH também esteja agindo nas células folículo estreladas e a secreção de ACTH também seja estimulada por IL-6. É interessante que o TSH, hormônio o qual já foi descrito como próinflamatório por aumentar a produção de IL-6 em células adiposas 3T3-L1 e em células adiposas humanas (ANTUNES et al. 2005; ANTUNES, et al. 2008) também provoque a liberação de ACTH pela hipófise, que estimulará a síntese e secreção de corticosterona, um hormônio com propriedades anti-inflamatórias. Esse contrabalanço pode ser um mecanismo interessante de se regular a atividade inflamatória nesses tecidos. 
No experimento agudo, in vivo, demonstrou-se que o conteúdo reduzido de mRNA da POMC no grupo Tx foi rapidamente aumentado quando os animais foram tratados por $30 \mathrm{~min}$ com dose suprafisiológica de T3. Esse aumento de conteúdo pode ter ocorrido por uma elevação da transcrição ou por uma redução da degradação desse mRNA. A estabilidade dos mRNAs pode ser alterada por modificações na cauda poli(A) na extremidade 3' e no cap 7 metil guanosina na extremidade 5', onde a redução da cauda poli(A) ou uma remoção do cap estão relacionados com redução da estabilidade desse transcrito (SCHOENBERG; MAQUAT, 2012; ZHANG; VIRTANEN; KLEIMAN, 2010). Ao analisarmos a cauda poli(A) do mRNA da POMC no grupo tratado com dose de $100 \mu \mathrm{g} / 100 \mathrm{~g}$ peso, não detectamos nenhuma alteração em relação ao seu tamanho que possa justificar um aumento na estabilidade do RNA, que nesse caso pode estar sendo aumentada por alterações no cap 7 metil guanosina. Considerando a rapidez dessa resposta, e que as ações clássicas dos HTs, conhecidas como genômicas (SHIBUSAWA et al, 2003), são em geral de resposta mais lenta, é possível que esse aumento da expressão gênica da POMC possa ser um indício de uma ação não genômica, que poderia ser desencadeada pelo T3, sem excluir a possibilidade de uma ação genômica do mesmo.

$\mathrm{O}$ conteúdo proteico de POMC e ACTH no experimento in vivo agudo não se mostrou alterado nos grupos estudados, graças a possíveis mecanismos de contrabalanço já citados anteriormente, como aumento da cauda poli(A) e aumento da expressão de PC1. Existe uma tendência em redução do conteúdo de ACTH nos animais Tx tratados com T3, porém não detectamos alterações nas concentrações séricas de ACTH desses animais, significando que o ACTH não está sendo secretado. Em outros grupos celulares da hipófise, o T3 se mostrou capaz de aumentar rapidamente a secreção de GH (SILVA et al., 2006) e inibir a secreção de TSHb (BARGI-SOUZA et al., 2014), porém essa modulação rápida na secreção não foi verificada nos corticotrofos. Nota-se que os animais submetidos a tireoidectomia nos estudos agudos não apresentaram redução na secreção de ACTH como ocorreu com os animais do estudo crônico. Esses animais sofreram uma incisão próxima a veia jugular para a aplicação da injeção de T3 e é conhecido que lesões nos tecidos provocam a liberação de citocinas, como a IL-6, que em meia hora já são capazes de aumentar a secreção de ACTH, além de outras alterações como aumento na atividade simpática e mudanças imunológicas (DESBOROUGH, 2000).

Uma das características das ações não genômicas é a sua capacidade de ocorrer na presença de inibidores da transcrição gênica, como é o caso do experimento in vitro com células AtT-20 onde observamos que, mesmo na presença de actinomicina D, o T3 foi capaz de realizar a ação de aumentar o conteúdo do mRNA da POMC $\left(\mathrm{H}^{+} 10^{-9} \mathrm{M}=\mathrm{H}^{-1} 10^{-9} \mathrm{M}\right)$ em células 
cultivadas com soro depletado de HTs. Outro forte indício de que a ação descrita em nosso estudo in vitro é não genômica, foi o fato de que o tratamento das células AtT-20 com o peptídeo RGD, antes da adição de triiodotironina bloqueou essa ação do T3. Conforme comentado anteriormente, o RGD se liga ao sítio da integrina de membrana $\alpha v \beta 3$, com o qual o T3 interage desencadeando sua ação não genômica (CHENG; LEONARD; DAVIS, 2010). Vias como a MAPK e PI3K podem ativar a transcrição gênica quando ocorre a ligação do T3 a integrina de membrana $\alpha$ V $\beta 3$ (DAVIS; LEONARD; DAVIS, 2008; KALYANARAMAN et al., 2014; LIN et al., 2009), bem como acionar mecanismos paralelos pós-transcricionais que poderiam promover essa elevação do conteúdo de mRNA da POMC de forma tão rápida. 


\section{CONCLUSÃO}

Concluímos que existe participação dos componentes do eixo hipotálamo-hipófisetireoide na regulação do eixo hipotálamo-hipófise-adrenal, com uma ação mais relevante na hipófise. Uma série de mecanismos compensatórios são ativados em animais tireoidectomizados com o intuito de se manter a expressão de POMC e ACTH, porém a secreção de ACTH mesmo assim encontra-se prejudicada nesses animais. O T3 se mostrou capaz de regular mecanismos transcricionais e pós-transcricionais envolvidos na síntese de POMC e ACTH e reestabelecer a secreção de ACTH em animais tireoidectomizados, além de estimular a transcrição de SF-1 em cultura primária de adrenais. Por fim, o TSH se mostrou um novo fator parácrino que regula positivamente a secreção de ACTH em cultura de células hipofisárias. 


\section{REFERÊNCIAS*}

ANTUNES, T.T.; GAGNON, A.; BELL, A.; SORISKY, A. Thyroid-stimulating hormone stimulates interleukin-6 release from 3T3-L1 adipocytes through a cAMP-protein kinase A pathway. Obesity Research, v. 13, p. 2066-2071, 2005

ANTUNES, T.T.; GAGNON, A.; LANGILLE, M.L.; SORISKY, A. Thyroid-stimulating hormone induces interleukin-6 release from human adipocytes through activation of the nuclear factor-kappa B pathway. Endocrinology, v. 149, p. 3062-3066, 2008.

BARGI-SOUZA, P.; KUCKA, M.; BJELOBABA, I.; TOMIĆ, M.; JANJIC, M.M.; NUNES, M. T.; STOJILKOVIC, S. S. Loss of Basal and TRH-Stimulated Tshb Expression in Dispersed Pituitary Cells. Endocrinology, v. 156, n. 1, p. 242-254, 2015.

BARGI-SOUZA, P.; ROMANO, R.M.; SALGADO, R.M.; GOULART-SILVA, F.; BRUNETTO E.L.; ZORN, T.M.T.; NUNES, M.T. Triiodothyronine Rapidly Alters the TSH Content and the Secretory Granules Distribution in Male Rat Thyrotrophs by a Cytoskeleton Rearrangement-Independent Mechanism. Endocrinology, v. 155, n. 9, p. 3725-3735, 2014.

BENJANNET, S.; RONDEAU, N.; DAY, R.; CHRÉTIEN, M.; SEIDAH, N.G. PC1 and PC2 are proprotein convertases capable of cleaving proopiomelanocortin at distinct pairs of basic residues. Proceedings of the National Academy of Sciences, v. 88, p. 3564-3568, 1991.

BERNAL, J.; GUADAÑO-FERRAZ, A.; MORTE, B. Thyroid hormone transportes - functions and clinical implications. Nature Reviews Endocrinology., v. 11, p. 406-417, 2015.

BIANCO, A.C.; NUNES, M.T.; HELL, N.S.; MACIEL, R.M. The role of glucocorticoids in the stress-induced reduction of extrathyroidal 3,5,3'-triiodothyronine generation in rats. Endocrinology, v. 120, n. 3, p. 1033-1038, 1987.

BIANCO, A.C.; SALVATORE, D.; GEREBEN, B.; BERRY, M.J.; LARSEN, P.R. Biochemistry, cellular and molecular biology, and physiological roles of the iodothyronine selenodeiodinases. Endocrine Reviews, v. 23, n. 1, p. 38-89, 2002.

BROKKEN, L.J.; SCHEENHART, J.W.; WIERSINGA, W.M.; PRUMMEL, M.F. Suppression of Serum TSH by Graves' Ig: Evidence for a Functional Pituitary TSH Receptor. The Journal of Clinical Endocrinology \& Metabolism, v. 86, n. 10, p. 4814-4817, 2001.

CALOGERO, A.E.; GALLUCCI, W.T.; GOLD, P.W.; CHROUSOS, G.P.. Multiple feedback regulatory loops upon rat hypothalamic corticotropin releasing hormone secretion. Potential clinical implications. Journal of Clinical Investigation, v. 82, p. 767-774, 1988.

CARON, K.M.; IKEDA, Y.; SOO, S.C.; STOCCO, D.M.; PARKER, K.L.; CLARK, B.J. Characterization of the promoter region of the mouse gene encoding the steroidogenic acute regulatory protein. Molecular Endocrinology, v. 11, p. 138-147, 1997.

*De acordo com:

ASSOCIAÇÃO BRASILEIRA DE NORMAS TÉCNICAS. NBR6023: informação e documentação:

referências: elaboração. Rio de Janeiro, 2002. 
CHENG, S.Y.; LEONARD, J.L.; DAVIS, P.J. Molecular Aspects of Thyroid Hormone Actions. Endocrine Reviews, v. 31, p. 139-170, 2010.

CHOMCZYNSKI, P.; SACCHI, N. Single-step method of RNA isolation by acid guanidinium thiocyanante-phenol-chloroform extraction. Analytical Biochemistry., v. 162, p. 156-159, 1987.

CHROUSOS, G.P. The hypothalamic-pituitary-adrenal axis and immune-mediated inflammation. The New England Journal of Medicine, v. 332, n. 20, p. 1351-1362, 1995.

CODY, V.; DAVIS P.J.; DAVIS F.B. Molecular modeling of the thyroid hormone interactions with alpha v beta 3 integrin. Steroids, v. 72, p. 165-170, 2007.

DA SILVA, F.G.; GIANNOCCO, G.; SANTOS, M.F.; NUNES, M.T. Thyroid Hormone Induction of Actin Polymerization in Somatotrophs of Hypothyroid Rats: Potential Repercussions in Growth Hormone Synthesis and Secretion. Endocrinology, v. 147, p. 57775785, 2006.

DA SILVA, F.G.; GIANNOCCO, G.; LUCHESSI, A.D.; CURI, R.; NUNES, M.T. T3 acutely increases GH mRNA translation rate and $\mathrm{GH}$ secretion in hypothyroid rats. Molecular and Cellular Endocrinology, v. 317, p. 1-7, 2010.

DAVIES, T.; MARIANS, R.; LATIF, R. The TSH receptor reveals itself. The Journal of Clinical Endocrinology \& Metabolism, v. 110, n. 2, p. 161-164, 2002.

DAVIS, P. J.; DAVIS, F. B. Nongenomic actions of thyroid hormone. Thyroid, v. 6, p. 497504, 1996.

DAVIS, P.J.; DAVIS, F.B.; CODY, V. Membrane receptors mediating thyroid hormone action. Trends in Endocrinology and Metabolism, v. 16, p. 429-435, 2005.

DAVIS, P.J.; GOGLIA, F.; LEONARD, J.L. Nongenomic actions of thyroid hormone. Nature Reviews Endocrinology., v. 12, p. 111-121, 2015.

DAVIS, P. J.; LEONARD, J. L.; DAVIS, F. B. Mechanisms of nongenomic actions of thyroid hormone. Frontiers in Neuroendocrinology, v. 29, p. 211-218, 2008.

DESBOROUGH, J.P. The stress response to trauma and surgery. British Journal of Anaesthesia, v. 85, n. 1, p. 109-117, 2000.

DENEF, C. Paracrinicity: The Story of 30 Years of Cellular Pituitary Crosstalk. Journal of Neuroendocrinology, v. 20, n. 1, p. 1-70, 2008.

DUPREZ, L.; PARMA, J.; VAN SANDE, J.; RODIEN, P.; DUMONT, J.E.; VASSART, G.; ABRAMOWICZ, M. TSH receptor mutations and thyroid disease. Trends in Endocrinology and Metabolism, v. 9, p. 133-139, 1998. 
ELIAS, L.L.K.; FERNANDES-ROSA, F.L.; ANTUNES-RODRIGUES, J.; CASTRO, M. Fisiologia da glândula adrenal. In: AIRES, M. M. (ed.) Fisiologia. 3. ed. Rio de Janeiro: Guanabara-Koogan, 2008. p. 1015-1031.

FULLER, R.W. The involvement of serotonin in regulation of pituitary adrenocortical function. Frontiers in Neuroendocrinology, vol. 13, p. 250-270, 1992.

GALTON, V.A. The history of 3,5,3'-triiodothyronine. Thyroid, v. 23, p. 9-13, 2013.

GETTEMANS, J.; VAN IMPE, K.; DELANOTE, V.; HUBERT, T.; VANDEKERCKHOVE, J.; DE CORTE, V. Nuclear actin-binding proteins as modulators of gene transcription. Traffic, v. 6, p. 847-857, 2005.

GILLIES, G.E.; LINTON, E.A.; LOWRY, P.J. Corticotropin releasing activity of the new CRF is potentiated several times by vasopressin. Nature, v. 299, p. 355-357, 1982.

GOULART-SILVA, F.; SOUZA, P.B.; NUNES, M.T. T3 rapidly modulates TSH $\beta$ mRNA stability and translational rate in the pituitary of hypothyroid rats. Molecular and Cellular Endocrinology, v. 332, p. 277-282, 2011.

HADDAD, F.; QIN, A. X.; McCUE, S. A.; BALDWIN, K. M. American Journal of Physiology - Endocrinology and Metabolism, v. 274, p. 1018-1026, 1998.

HANUKOGLU, I. Steroidogenic enzymes: Structure, function, and role in regulation of steroid hormone biosynthesis. The Journal of Steroid Biochemistry and Molecular Biology, v. 43, n. 8, p. 779-804, 1992.

HARROLD, S.; GENOVESE, C.; KROBIN, B.; MORRISON, S.L.; MILCAREK, C. A comparison os apparent mRNA half-life using kinetic labeling techniques vs decay following administration of transcriptional inhibitors. Analytical Biochemistry, v. 198, p. 19-29, 1991.

HELMREICH, D.L.; TYLEE, D. Thyroid hormone regulation by stress and behavioral differences in adult male rats. Hormones and behavior, v. 60, n. 3, p. 284-291, 2011.

HOIVIK, E.A.; LEWIS, A.E.; AUMO, L.; BAKKE, M. Molecular aspects of steroidogenic factor 1 (SF-1). Molecular and Cellular Endocrinology, v. 315, p. 27-39, 2010.

HORNSBY, P.J. Regulation of adrenocortical cell proliferation in culture. Endocrine Research, v. 10, p. 259-281, 1985.

JANSEN, J.; FRIESEMA, E.C.; MILICI, C.; VISSER, T.J. Thyroid hormone transporters in health and disease. Thyroid, v. 15, p. 757-768, 2005.

JENKS, B.G. Regulation of Proopiomelanocortin Gene Expression. Trends in Comparative Endocrinology and Neurobiology: Annals of the New York Academy of Sciences, v. 1163, p. 17-30, 2009.

JOHNSON, E.O.; KAMILARIS, T.C.; CALOGERO, A.E.; GOLD, P.W.; CHROUSOS, G.P. Experimentally-induced hyperthyroidism is associated with activation of the rat hypothalamicpituitary-adrenal axis. European Journal of Endocrinology, v. 153, n. 1, p. 177-185, 2005. 
JOHNSON, E.O.; CALOGERO, A.E.; KONSTANDI, M.; KAMILARIS, T.C.; LA VIGNERA, S.; CHROUSOS, G.P. Effects of short- and long-duration hypothyroidism on hypothalamic-pituitary-adrenal axis function in rats: in vitro and in situ studies. Endocrine, v. 42, n. 3, p. 684-693, 2012.

JOHNSON, E.O.; CALOGERO, A.E.; KONSTANDI, M.; KAMILARIS, T.C.; LA VIGNERA, S.; CHROUSOS, G.P. Effects of experimentally induced hyperthyroidism on central hypothalamic-pituitary-adrenal axis function in rats: in vitro and in situ studies. Pituitary, v. 16, n. 2, p. 275-286, 2013.

JOHNSON, E.O.; KAMILARIS, T.C.; CALOGERO, A.E.; KONSTANDI, M.; CHROUSOS, G.P. Effects of short- and long-duration hypothyroidism on function of the rat hypothalamicpituitary-adrenal axis. Journal of endocrinological investigation, v. 36, n. 2, p. 104-110, 2013.

JOSEPH-BRAVO, P; JAIMES-HOY, L.; URIBE, R.M.; CHARLI, J.L. 60 years of neuroendocrinology: TRH, the first hypophysiotropic releasing hormone isolated: control of the pituitary-thyroid axis. Journal of Endocrinology, v. 226, n. 2, p. 85-100, 2015.

KALYANARAMAN, H.; SCHWAPPACHER, R.; JOSHUA, J.; ZHUANG, S.; SCOTT, B.T.; KLOS, M.; CASTEEL, D.E.; FRANGOS, J.A.; DILLMANN, W.; BOSS, G.R.; PILZ, R.B. Nongenomic thyroid hormone signaling occurs through a plasma membrane-localized receptor. Science signaling, v. 7, n. 326, 2014.

KEVIN, N.; BLUM, M.; ROBERTS, J.L. Modulation of basal and corticotropin releasing factor stimulated proopiomelanocortin gene expression by vasopressin in rat anterior pituitary. Endocrinology, v. 125, p. 2957-2966, 1989.

KIMURA, E.T. Glândula tireóide. In: AIRES, M. M. (ed.) Fisiologia. 3. ed. Rio de Janeiro: Guanabara-Koogan, 2008. p. 991-1014.

KISHIMOTO, T. IL-6: from its discovery to clinical applications. International immunology, v. 22 , n. 5, p. 347-352, 2010.

KRANE, I.M.; SPINDEL, E.R.; CHIN, W.W. Thyroid hormone decreases the stability and the poly(A) tract length of rat thyrotropin beta-subunit messenger RNA. Molecular Endocrinology, v. 5, n. 4, p. 469-475, 1991.

LEI, J.; BHARGAVA, M.; INGBAR, D. H. Cell-specific signal transduction pathways regulating $\mathrm{Na}+-\mathrm{K}+-\mathrm{ATPase}$. Focus on short-term effects of thyroid hormones on the $\mathrm{Na}+-\mathrm{K}+-$ ATPase activity of chick embryo hepatocytes during development: focus on signal transduction'. American Journal of Physiology - Cell Physiology, v. 296, p. C1-C3, 2009.

LIN, H.Y.; SUN, M.; TANG, H.Y.; LIN, C.; LUIDENS, M.K.; MOUSA, S.A.; INCERPI, S.; DRUSANO, G.L.; DAVIS, F.B.; DAVIS, P.J. L-Thyroxine vs. 3,5,3'-triiodo-L-thyronine and cell proliferation: activation of mitogen-activated protein kinase and phosphatidylinositol 3kinase. American Journal of Physiology Cell Physiology, v. 296, n. 5, p. 980-991, 2009. 
LINDHOLM, J.; LAURBERG, P. Hypothyroidism and Thyroid Substitution: Historical Aspects. Journal of Thyroid Research, v. 2011, 10 p, 2011.

LIU, D; WAXMAN, D.J. Post-transcriptional regulation of hepatic NADPH-cytochrome P450 reductase by thyroid hormone: independent effects on poly(A) tail length and mRNA stability. Molecular Pharmacology, v. 61, n. 5, p. 1089-1096, 2002.

LUO, X.; IKEDA, Y.; PARKER, K.L. A cell-specific nuclear receptor is essential for adrenal and gonadal development and sexual differentiation. Cell, v. 77, p. 481-490, 1994.

MATTOS, G.E.; LOTFI. C.F. Differences between the growth regulatory pathways in primary rat adrenal cells and mouse tumor cell line. Molecular and Cellular Endocrinology, v. 245, p. 31-42, 2005.

MULLUR, R.; LIU, Y.Y.; BRENT, G.A. Thyroid hormone regulation of metabolism. Physiological reviews, v. 94., n. 2, p. 355-382, 2014.

MURPHY, D.; PARDY, K.; SEAH, V.; CARTER, D. Posttranscriprional Regulation of Rat Growth hormone Gene Expression: increased message Stability and Nuclear polyadenylation accompany Thyrois Hormone Depletion. Molecular and Cellular Biology, v. 12, n. 6, p. 26242632, 1992.

NICOLAIDES, N.C.; KYRATZI, E.; LAMPROKOSTOPOULOU, A.; CHROUSOS, G.P.; CHARMANDARI, E. Stress, the stress system and the role of glucocorticoids. Neuroimmunomodulation, v. 22, n. 1-2, p. 6-19, 2015.

NUNES, M.T. A glândula hipófise. In: AIRES, M. M. (ed.) Fisiologia. 3. ed. Rio de Janeiro: Guanabara-Koogan, 2008. p. 952-979.

OETTING, A.; YEN, P.M. New insights into thyroid hormone action. Best Practice \& Research Clinical Endocrinology \& Metabolism, v. 21, n. 2, p. 193-208, 2007.

ORTIGA-CARVALHO, T.M.; SIDHAYE, A.R.; WONDISFORD, F.E. Thyroid hormone receptors and resistance to thyroid hormone disorders. Nature Reviews Endocrinology, v. 10, p. 582-591, 2014.

PARKER, K.L.; SCHIMMER, B.P. Steroidogenic Factor 1: A Key Determinant of Endocrine Development and Function. Endocrine reviews, v. 18, p. 361-377, 1997.

PORTULANO, C.; PARODER-BELENITSKY, M.; CARRASCO, N. The Na+/I- symporter (NIS): mechanism and medical impact. Endocrine Reviews, v. 35, p. 106-149, 2014.

PRUMMEL, M.F.; BROKKEN, L.J.; MEDURI, G.; MISRAHI, M.; BAKKER, O; WIERSINGA, W.M. Expression of the thyroid-stimulating hormone receptor in the folliculostellate cells of the human anterior pituitary. The Journal of Clinical Endocrinology \& Metabolism, v. 85, p. 4347-4353, 2000.

RAFFIN-SANSON, M.L.; KEYZER, Y.; BERTAGNA, X. Proopiomelanocortin, a polypeptide precursor with multiple functions: from physiology to pathological conditions. European Journal of Endocrinology, v. 149, p. 79-90, 2003. 
RENNER, U.; GLODDEK, J.; PEREDA, M.P.; ARZT, E.; STALLA, G.K. Regulation and role of intrapituitary IL-6 production by folliculostellate cells. Domestic Animals Endocrinology, v. 15, n. 5, p. 353-362, 1998.

RICHARDS, J.S. New Signaling Pathways for Hormones and Cyclic Adenosine 3',5'Monophosphate Action in Endocrine Cells. Molecular Endocrinology, v. 15, p. 209-218, 2008.

RIVIER, C. Does IL-6 release ACTH by exerting a direct effect in the rat anterior pituitary. STRESS, v. 4, n. 1, p. 39-55, 2001.

ROMANO, R.M.; BARGI-SOUZA, P.; BRUNETTO, E.L.; GOULART-SILVA, F.; AVELLAR, M.C.W.; OLIVEIRA, C.A.; NUNES, M.T. Hypothyroidism in Adult Male Rats Alters Posttranscriptional Mechanisms of Luteinizing Hormone Biosynthesis. Thyroid, v. 23, p. 497-505, 2013.

SALLÉS, F. J.; RICHARDS, W. G.; STRICKLAND, S. Assaying the Polyadenilation State of mRNAs. Methods: A Companion to Methods in Enzimology, v. 17, p. 38-45, 1999.

SAPOLSKY, R.; RIVIER, C.; YAMAMOTO, G.; PLOTSKY, P.; VALE, W. Interleukin-1 stimulates the secretion of hyphotalamic corticotropin releasing factor. Science, v. 238, p. 522524, 1987.

SCARLETT, A.; PARSONS, M.P.; HANSON, P.L.; SIDHU, K.K.; MILLIGAN, T.P.; BURRIN, J.M. Thyroid hormone stimulation of extracellular signal-regulated kinase and cell proliferation in human osteoblast-like cells is initiated at integrin alphaVbeta3. Journal of Endocrinology, v. 196, n. 3. P. 509-517, 2008.

SCHOENBERG, D.R.; MAQUAT, L.E. Regulation of cytoplasmic mRNA decay. Nature Reviews Genetics, v. 13, n. 4, p. 246-259, 2012.

SHIBUSAWA, N.; HOLLENBERG, A. N.; WONDISFORD, F. E. Thyroid Hormone Receptor DNA Binding is required for both Positive and Negative Gene Regulation. The Journal of Biological Chemistry, v. 278, n. 2, p. 732-738, 2003.

SHUPNIK, M.A.; CHIN, W.W.; ROSS, D.S.; DOWNING, M.F.; HABENER, J.F.; RIDGWAY, C. Regulation by thyroxine of mRNA encoding the Subunit of Mouse Thyrotropin. The Journal of Biological Chemistry, v. 258, n. 24, p. 15120-15124, 1983.

SHUPNIK, M.A.; ARDISSON, L.J.; MESKELL, M.J.; BORNSTEIN, J; RIDGWAY, E.C. Triiodothyronine (T3) regulation of thyrotropin subunit gene transcription is proportional to T3 nuclear receptor occupancy. Endocrinology, v. 118, p. 367-371, 1986.

SILVA, F.G.; GIANNOCCO, G.; SANTOS, M. F.; NUNES, M. T. Thyroid Hormone Induction of Actin Polymerization in Somatotrophs of Hypothyroid Rats: Potential Repercussions in Growth Hormone Synthesis and Secretion. Endocrinology, v. 147, p. 5777-5785, 2006. 
SILVA, F.G.; GIANNOCCO, G.; LUCHESSI, A.D.; CURI, R.; NUNES, M.T. T3 acutely increases GH mRNA translation rate and GH secretion in hypothyroid rats. Molecular and cellular endocrinology, v. 317, p. 1-7, 2010.

SORISKY, A; BELL, A.; GAGNON, A. TSH Receptor in adipose cells. Hormone and Metabolic Research, v. 32, p. 468-474, 2000.

STATON, M. J.; LEEDMAN, P. J.. Posttrancriptional Regulation of Thyrotropin $\beta$ - Subunit Messenger Ribonucleic Acid by Thyroid Hormone in Murine Thyrotrope Tumor Cells: A Conserved Mechanism across Species. Endocrinology, v. 139, n. 3, p. 1093-1100, 1998.

STOJILKOVIC, S.S. Molecular mechanisms of pituitary endocrine cell calcium handling. Cell calcium, v. 51, n. 3-4, p. 212-221, 2012.

STOJILKOVIC, S.S.; TABAK, J.; BERTRAM, R. Ion channels and signaling in the pituitary gland. Endocrine reviews, v. 31, n. 6, p. 845-915, 2010.

TSIGOS, C.; CHROUSOS, GP.. Hypothalamic-pituitary-adrenal axis, neuroendocrine factors and stress. Journal of psychosomatic research, v. 53, n. 4, p. 865-871, 2002.

VISSER, W.E.; FRIESEMA, E.C.; VISSER, T.J. Minireview: thyroid hormone transporters: the knowns and the unknowns. Molecular Endocrinology, v. 25, p. 1-14, 2011.

WONG, M.L.; AL SHEKHLEE, A.; BONGIORNO, P.B.; ESPOSITO, A.; KHATRI, P.; STERNBERG, E.M.; GOLD, P.W.; LICINIO, J. Localization of urocortin messenger RNA in rat brain and pituitary. Molecular Psychiatry, v. 1, p. 307-312, 1996.

YEN, P.J. Physiological and molecular basis of thyroid hormone action. Physiological reviews, v. 81, n. 3, p. 1097-1142, 2001.

ZHANG, X.; VIRTANEN, A.; KLEIMAN, F.E. To polyadenylate or to deadenylate: that is the question. Cell cycle, v. 9, n. 22, p. 4437-4449, 2010.

ZOELLER, R.T.; TAN, S.W.; TYL, R.W. General background on the hypothalamic-pituitarythyroid (HPT) axis. Critical reviews in toxicology, v. 37, n. 1-2, p. 11-53, 2007. 